VOX PATRUM 37 (2017) t. 67

Ks. Stanisław LONGOSZ*

\title{
CHRZEŚCIJAŃSKIE WIDOWISKA ZASTĘPCZE W PROPOZYCJI OJCÓW KOŚCIOLA
}

Znany jest powszechnie negatywny stosunek Ojców Kościoła do widowisk publicznych, ponieważ, ich zdaniem, miały one zawsze charakter niemoralny i idololatryczny ${ }^{1}$. Należały zaś do nich: widowiska teatralne (ludi scaenici, theatrales), a w nich przede wszystkim różnego rodzaju mimy i pantomima; widowiska amfiteatralne (munera), a w nich walki gladiatorskie (ludi gladiatorii), różnego rodzaju polowania (venationes) oraz naumachie

${ }^{*}$ Ks. dr hab. Stanisław Longosz - emerytowany profesor Katolickiego Uniwersytetu Lubelskiego Jana Pawła II; były dyrektor Instytutu Badań nad Antykiem Chrześcijańskim KUL oraz redaktor naczelny „Vox Patrum”; e-mail: longosz1@interia.pl.

${ }^{1}$ Por. m.in. P. Wolf, Die Stellung der Christen zu den Schauspielen nach Tertullians Schrift „De spectaculis”, Leipzig 1897; J.B. Eriau, Pourquoi les Pères de l'Église ont condamné le théatre de leur temps, Paris - Angers 1914; B.H. Vandenberhe, Saint Jean Chrysostome et les spectacles, ZRGG 7 (1955) 34-46; V. Power, Tertullian: father of clerical animosity toward the theatre, „Educational Theatre Journal" 23 (1971) 36-50; H. Jürgens, Pompa diaboli. Die lateinischen Kirchenväter und das antike Theater, Stuttgart 1972; W. Weismann, Kirche und Schauspiele. Die Schauspiele im Urteil der lateinischen Kirchenväter, unter besonderer Berücksichtigung von Augustin, Würzburg 1972; O. Pasquato, Gli spettacoli in S. Giovanni Crisostomo. Paganesimo e cristianesimo ad Antiochia e Costantinopoli nel IV secolo, Roma 1976; J. Śrutwa, Widowiska epoki klasycznej w ocenie Kościoła afrykańskiego II-V wieku, RTK 27 (1980) z. 4, 43-56; Ch. Schnusenberg, Das Verhältnis von Kirche und Theater. Dargestellt an ausgewählten Schriften der Kirchenväter und liturgischen Texten, Bern - Frankfurt 1981; T. Baumeister, Das Theater in der Sicht der alten Kirche, w: Theaterwesen und dramatische Literatur, hrsg. G. Holtus, Tübingen 1987, 109-124; W. Myszor, Teatr $i$ widowiska w ocenie greckich pisarzy kościelnych, w: Chrześcijanie a życie publiczne w Cesarstwie RzymskimNovatianus III-IV wieku, red. J. Śrutwa, Lublin 1988, 123-134; S. Longosz, Widowiska teatralne zagrożeniem dla życia rodzinnego wedlug św. Jana Chryzostoma. Wprowadzenie $i$ wybór tekstów, w: Chrześcijanie a życie publiczne, s. 135-198; tenże, Teatr miejscem kultu bóstw pogańskich w opinii autorów wczesnochrześcijańskich, „Acta Universitatis Nicolai Copernici. Historia” 27 (1992) t. 254, 135-149; E. Stanula, Widowiska w ocenie Ojców Kościoła, SaeCh 1 (1995) 7-16; R. Klein, „Spectaculorum voluptates adimere”. Zum Kampf der Kirchenväter gegen Circus und Theater, w: Theater, Theaterpraxis, Theaterkritik im Kaiserzeitlichen Rom, hrsg. J. Fugmann, München - Leipzig 2004, 155-174; M. Zawadzka, Kilka uwag o wschodniochrześcijańskiej krytyce rzymskich widowisk (na podstawie „,De spectaculis” Tertuliana, ,De spectaculis” Nowacjana, „De gubernatione Dei VI" Salwiana z Marsylii, VoxP 24 (2004) t. 46-47, 433-439; Jeux et spectacles dans l'antiquité tardive, ed. J.-M. Carrié, Turnhout 2007 = „Antiquité Tardive” 15 (2007); L. Lugaresi, Il teatro di Dio. Il problema degli spettacoli nel cristianesimo antico (II-IV secolo), Brescia 2008; Spectacula, ed. M. Vinzent - K. Schlapbach, Leuven - Paris 2013 = StPatr 60 (2013). 
(naumachiae); i widowiska cyrkowe (ludi circenses), a w nich wyścigi konne (keletes) i wyścigi rydwanów (aurigae). Przed niebezpieczeństwami płynącymi z ich oglądania ostrzegali Ojcowie w specjalnych pisanych przez siebie traktatach $^{2}$ lub ich częściach ${ }^{3}$ oraz w wygłaszanych kazaniach i homiliach ${ }^{4}$. Czynnych aktorów tych widowisk Kościół długo nie przyjmował w poczet swych członków lub decyzjami synodów wyłączał ze swej wspólnoty, dopóki nie zmienią swego zawodu ${ }^{5}$. Ojcowie Kościoła, w większości duszpasterze, zdawali sobie jednak sprawę, że same zakazy, nawet synodalne, nie wykorzenią pragnienia oglądania widowisk, jedynych publicznych i tak ważnych dla człowieka starożytnego gwarantowanych przyjemności (voluptates), nie wystarczą lub niewiele pomoga, ale w ich miejsce trzeba proponować wiernym pewne substraty, jakieś zastępcze zjawiska, historie, fakty lub elementy, które by wypełniały pustkę po pierwszych albo były podobne do nich, czyli jakieś zastępcze widowiska duchowe (spectacula spiritualia) lub typowo chrześcijańskie (spectacula christiana, spectacula a Deo contributa). Takie substraty, zamiast krwawych i często rozwiązłych widowisk, proponowali już wcześniej niektórzy rzymscy myśliciele pogańscy, zachęcając do podziwiania piękna natury i gwiaździstego nieba, lub do lektury pięknej poezji i literatury. Tak czynili przede wszystkim trzeźwo myślący filozofowie stoiccy, a wśród nich m. in. Cyceron, dla którego już sam wschód i zachód słońca i księżyca dostarczają ludziom tak cudownego widowiska, z jakim nie da się nic porównać ${ }^{6}$, a od widowiska ruchu planet nie ma nic piękniejszego ${ }^{7}$; podobnie wyrażał się Seneka, dla którego piękniejszym był prosty sposób życia pierwotnych ludzi

${ }^{2}$ Por. Tertullianus, De spectaculis, ed. E. Dekkers, CCL 1, Turnhout 1954, 227-253 lub ed. M. Turcan, SCh 332, Paris 1986, thum. W. Myszor, PSP 5, Warszawa 1970, 79-113; Novatianus, De spectaculis, ed. G.F. Diercks, CCL 4, Turnhout 1972, 167-179 lub ed. A. Saggioro: Novaziano, Gli spettacoli, Introduzione, testo, traduzione e commento, BPatr 37, Bologna 2001, thum. zbiorowe ze wstępem M. Eder, „Meander” 56 (2002) nr 2, 69-75.

${ }^{3}$ Por. m.in. Salvianus Massiliensis, De gubernatione Dei VI, éd. G. Lagarrigue, SCh 220, Paris 1975, 360-429, thum. T. Kołosowski, PSP 66, Warszawa 2010, 197-219.

${ }^{4}$ Por. m.in. Joannes Chrysostomus, Contra ludos et theatra, PG 56, 263-270, thum W. Kania, PSP 8, Warszawa 1971, 175-181; Jacobus Sarugensis, De ludis theatralibus, ed. C. Moss: Jacob of Serugh, Homilies on the spectacles of the theatre, „Le Muséon” 48 (1935) 87-112; Joannes Mandacunius, Homilia 17: Contra ludos theatrales, übers S. Weber, BKV 58,1. Reihe, Kempten München 1927, 184-192.

${ }^{5}$ Por. m.in. Concilium Eliberitanum (306) can. 62; Concilium Arelatense I (314) can. 5; Concilium Arelatense II (442-506) can. 20; Concilium Laodicense (380) can. 53-54; Concilium Carthaginense III (397) can. 11 i 35; Traditio Apostolica 16; Constitutiones Apostolorum VIII 32, 9; Testamentum Domini nostri Jesu Christi II 2; Canones Hippolyti (versio Arabica) can. 12; Canones Apostolorum (versio Arabica) can. 127; zob. A. Sarkissian, Skenikoi, mimoi and other defectors. Theatre in testimonies of early Christian legal decrees of Eastern Rome, „Eirene” 43 (2007) 194-202.

${ }^{6}$ Por. Cicero, De natura deorum II 155, ed. J.B. Mayor, vol. 2, Cambridge 1883, 60: „Iam vero circumitus solis et lunae [...] spectaculum hominibus praebent: nulla est enim insatiabilior species, nulla pulchrior".

${ }^{7}$ Por. tamże II 104, ed. Mayor, vol. 2, s. 38: „Quo spectaculo nihil potest admirabilius esse nihil 
pod gwieździstym niebem od przepychu widowisk i luksusu współczesnych domów mieszkalnych ${ }^{8}$, czy też satyryk Juwenal, który proponował, by bezwstydne widowiska w teatrze zastąpić na towarzyskich spotkaniach i ucztach śpiewem lub recytacją Iliady Homera czy Eneidy Wergiliusza, zapewniając, że tego rodzaju ,nasze spotkania dadzą dziś także i inne widowiska" ${ }^{\text {.To za- }}$ chowanie myślicieli pogańskich, którzy proponowali oglądanie raczej gwieździstego nieba i piękna przyrody jako widoków godniejszych człowieka, niż podziwianie przepychu publicznych widowisk oraz luksusu pałaców i wspaniałych strojów, zauważy później również chrześcijański retor Laktancjusz ${ }^{10}$.

Aby zatem po chrześcijańsku zaspokoić pragnienie oglądania widowisk publicznych przez wiernych, Kościół starożytny zaczął duszpastersko działać głównie na dwóch polach: praktycznie na polu liturgicznym oraz teoretycznie i duszpastersko na polu homiletyczno-literackim.

Najpierw do tworzącej się liturgii chrześcijańskiej Kościół wprowadził szereg teatralnych i procesjonalnych elementów, zaczerpniętych $w$ jakiejś mierze z uroczystej pompy, od której zazwyczaj rozpoczynano widowiska: zamiast podziwianej przez wszystkich widzów procesji z posagami bóstw patronalnych i mającymi wystąpić aktorami oraz hałaśliwą muzyką i chóralnymi aklamacjami, przemierzającej przez teren cyrku, teatru i amfiteatru przed rozpoczęciem przedstawienia ${ }^{11}$, wprowadzono uroczyste wejścia do kościoła

pulchrius”; zob. tamże II 140; Tusculanae disputationes I 45; K. Schlapbach, Spectaculum naturae as , theatrical” experience: new uses of an ,old comparison”, StPatr 44 (2011) 421-426.

${ }^{8}$ Por. Seneca, Epistula 90, 41-43, ed. R.M. Gummere, t. 2, London - New York 1920, 426, tłum. W. Kornatowski: Seneka, Listy moralne do Lucyliusza, Warszawa 2010, 387: ,Jakże rozkoszny sen zapewniała tamtym twarda ziemia! Nie wisiały nad nimi ozdobione rzeźbami stropy, lecz nad spoczywającymi na otwartej przestrzeni przesuwały się gwiazdy, a niebo, które przedstawia w nocy tak wspaniały widok, uciekało gdzieś w przepastny głąb, wykonując ten wielki ruch zupełnej ciszy. Widok tej najpiękniejszej budowli był dostępny dla nich tak za dnia, jak i w nocy. Miło im było przyglądać się gwiazdom chylącym się ze środkowej części nieba ku zachodowi, a innym znów wyłaniającym się dopiero ze swego ukrycia. I dlaczegóż by nie miała ich cieszyć wędrówka pośród tak szeroko rozsianych cudów? [...] Tamci nie mieli domów wzniesionych na kształt miast. Mieli natomiast powietrze i swobodne przewiewy na otwartych przestrzeniach; mieli przyjemny cień od skały lub od drzewa; mieli przejrzyste zdroje i potoki nie zeszpecone ani budowlami, ani urządzeniami wodociagowymi, ani przymusowym skierowaniem do sztucznych koryt, potoki biegnące całkiem nieskrępowanie; mieli piękne bez żadnych sztucznych przydatków łąki, a wśród tego wszystkiego proste, dokładnie sklecone ręką wieśniaczą mieszkania. To był dom odpowiadający wymaganiom natury, dom, w którym przyjemnie było mieszkać nie znając obaw ani z jego strony, ani o niego"; zob. też Seneca, De consolatione Helviae 20, 1-2.

${ }^{9}$ Por. Juvenalis, Satura XI 179, ed. J.D. Duff, Cambridge 1966, 81: „Nostra dabunt alios hodie convivia ludos".

${ }^{10}$ Por. Lactantius, Divinae institutiones VI 20, 6-8, S. Brandt - G. Laubmann, CSEL 19, 557 : „Aiunt enim multo esse praeclarius et homine dignius coelum potius quam caelata intueri et hoc pulcherrimum opus intermicantibus astrorum luminibus tamquam floribus adornatum quam picta et ficta et gemmis distincta mirari".

${ }^{11}$ Opis procesji cyrkowej (pompa circensis) zob. np. Dionysius Halicarnensis, Antiquitates Romanae VII 72; II 71; por. także: R.L. Taylor, The ,, sellisternium” and the theatrical „pompa”, CPh 
na rozpoczęcie nabożeństwa, z antyfonicznym lub responsorialnym śpiewem psalmów, wersetów i hymnów, przez celebransa, wiernych i służbę liturgiczną, z dialogowaniem homilii lub innych części liturgii, które dawały początek przyszłym dramatom liturgicznym ${ }^{12}$, czy też uroczystym składaniem darów ofiarnych. W miejsce tradycyjnych świąt pogańskich z procesjami, ofiarami i zwyczajami Kościół wprowadzał uroczyste liturgie świąt Wielkanocy, Bożego Narodzenia, Epifanii czy niedzieli, z odpowiednimi wigiliami, nocnymi czuwaniami czy procesjami, zwłaszcza do grobów męczenników, z uroczystymi translacjami ich relikwii, z uroczystą długo przygotowywaną liturgią chrztu czy sakramentu pojednania. Dramaturgię i przeżywanie mitologicznych wydarzeń klasycznych tragedii zastępowano przypominanymi podczas liturgii relacjami męczeństw zamordowanych podczas prześladowań chrześcijan, których czczono na wzór starożytnych herosów oraz uwielbiano tworzonymi hymnami, panegirykami lub specjalną liturgia; chrześcijanie bowiem starożytni nie stworzyli nigdy własnych tragedii, nie urządzali własnych chrześcijańskich przedstawień, ani nie posiadali swoich teatrów. Wszystkie te uroczyste liturgiczne imprezy miały zastąpić niemoralne i idololatryczne widowiska pogańskie, wypełnić po nich pustkę oraz zaspokoić pragnienia starożytnych chrześcijan.

Oprócz widowiskowych elementów wprowadzanych do liturgii, która swym blaskiem i solennością miała w jakiś sposób zastąpić przepych publicznych widowisk oraz zaspokoić pragnienie i przyjemność ich oglądania, Ojcowie Kościoła w swoich pismach, kazaniach i homiliach wskazywali często wiele innych zastępczych, równie pięknych widoków, faktów i historii oraz zachęcali do ich podziwiania. Zdawali sobie sprawę, że nie jest łatwo, a nawet niemożliwe, wyrwać i usunąć głęboko zakorzenione u starożytnego człowieka pragnienie i chęć oglądania i pasjonowania się widowiskami, stanowiącymi jedną z zagwarantowanych mu publicznych przyjemności; tę więc niegodną chrześcijanina przyjemność starali się zastępować innymi, równie ciekawymi, ale moralnymi atrakcjami. Zaczęli więc w swych pismach, zwłaszcza w mowach i homiliach, wynajdywać, przypominać i proponować różnego rodzaju obrazy i cuda natury, szczególnie bardziej udramatyzowane wydarzenia i sceny biblijne, które w wyobraźni słuchaczy miały zastąpić często niemoralne

30 (1935) 122-130; A. Piganiol, Recherches sur les jeux Romains, Strasbourg 1923, 15-31; D. Ales, Pompa diaboli, RSR 1 (1910) 571-590; H. Rahner, Pompa diaboli. Ein Beitrag zur Bedeutungsgeschichte des Wortes pompe-pompa in der urchristlichen Taufliturgie, ZKTh 55 (1931) 239-273; J.H. Waszink, Pompa diaboli, VigCh 1 (1947) 13-41; M. Turcan, Aedes solis au grand cirque, REL 36 (1958) 255-262; J.A. Hanson, Roman theater-temples, Princeton 1959, 82-86; F. Boemer, Pompa, RE XXI 2, 1878-1994, 2548-2549; Longosz, Teatr miejscem kultu bóstw pogańskich, s. 139.

${ }_{12}$ Por. S. Longosz, Zalażki dramatu chrześcijańskiego $w$ literaturze patrystycznej, RH 44 (1996) z. 3, 263-273; tenże, I Germi del dramma cristiano nella letteratura patristica, StPatr 31 (1997) 59-69; J. Oroz Reta, Du théâtre classique au théâtre religieux, w: Association G. Budé, Actes IX Congres (13-18 IV 1973), Paris 1975, 493-499; S. Longosz, Dramatyzowane homilie patrystyczne zalażkiem dramatu chrześcijańskiego, VoxP 36 (2016) t. 65, 389-431. 
widowiska publiczne; należeli zaś do nich przede wszystkim: Tertulian, Nowacjan, Cyprian, Jan Chryzostom, Augustyn oraz Quodvultdeus.

\section{TERTULIAN}

Pierwszym chrześcijańskim autorem, który na szerszą skalę zaczął to czynić, był kartagiński świecki retor Quintus Septymiusz Tertulian († 220), który w specjalnym napisanym ok. 200 roku traktacie De spectaculis nie tylko zdecydowanie potępił wszelkie ówczesne widowiska publiczne (które bardzo często nazywa „przyjemnościami” - voluptates) ${ }^{13}$ jako imprezy o charakterze idololatrycznym i niemoralnym ${ }^{14}$, ale również pod jego koniec ${ }^{15}$ przedstawił listę różnego rodzaju historii, prawd, faktów i widoków, jako chrześcijańskich świętych, wieczystych i darmowych widowisk, imprez i przyjemności, darowanych przez Boga (tales voluptates a Deo contributas [...] hae voluptates, haec spectacula christianorum, sancta, perpetua, gratuita $)^{16}$. Że chrześcijanie unikają publicznych widowisk, a wybierają sobie inne przyjemności, przekonywał Tertulian pogańskich adresatów już wcześniej, w 197 r. w swoim Apologetyku, gdzie czytamy:

„Wstrzymujemy się od waszych widowisk, jak i od ich początków, wiedząc, że powstały z zabobonów, a od rzeczy, które są ich treścią, trzymamy się całkiem $z$ daleka. Ani w mowie, ani w patrzeniu, ani w słuchaniu nie mamy nic wspólnego z szaleństwem cyrku, z bezwstydem teatru, z okropnościami areny, z różnościami atletycznych popisów na palestrze. W czym was obrażamy? Jeśli wybieramy sobie inne przyjemności (Si alias praesumimus voluptates), jeśli nawet nie chcemy się zabawić, nasza to krzywda, nie wasza. My gardzimy tym, co wam się podoba, wy zaś także tym, co nasze, nie znajdujecie przyjemności"' ${ }^{17}$.

Tertulian dobrze znał pasje i upodobania swoich kartagińskich rodaków, w tym także szaleńczą namiętność oglądania widowisk publicznych ${ }^{18}$. Znał również kuszącą moc i siłę przyjemności wynikającą z oglądania widowisk, zagrażającą nie tylko niedoświadczonym katechumenom, ale i dojrzałym chrześcija-

${ }^{13} \mathrm{~W}$ tym traktacie terminu tego użył aż 34 razy, zaznaczając też: „species autem voluptatis etiam spectacula" (De spectaculis 14, 2, CCL 1, 240); por. G. Claesson, Index Tertullianeus, III, Paris 1975, 1756; o moralnym jego znaczeniu u Tertuliana zob. C. Rambeaux, Tertullien face aux morales des trois premiers siècles, Paris 1979, 170-179, 344-347; A. Kessler, Tertullian und das Vergnügen in „De spectaculis”, „Zeitschrift für Philosophie und Theologie” 41 (1994) 313-353, spec. s. 314-316 (Ort, Häufigkeit, Bedeutungen und Synonyme von „voluptas”).

${ }^{14}$ Por. Tertullianus, De spectaculis $4-13$ i 15-19.

${ }^{15}$ Por. tamże 29-30.

${ }^{16}$ Por. tamże 29, 1 i 3, SCh 332, 306 i 310.

${ }^{17}$ Tenże, Apologeticum 38, 4-5, CCL 1, 150, thum. J. Sajdak, POK 20, Poznań 1947, 154-155.

${ }^{18}$ Por. G. Schöllgen, Die Teilnahme der Christen am städtischen Leben in vorkonstantinischer Zeit. Tertullians Zeugnis für Karthago, RQ 77 (1982) 1-29; B. Burliga, Tertullian on the paradox of the Roman amphitheatre games (De spectaculis 22), VoxP 36 (2016) t. 65, 119-127. 
nom, dlatego pragnie ich ostrzec i pouczyć, by przez niewiedzę im nie ulegali, przypominając, że nie dadzą się one pogodzić ze złożonymi przyrzeczeniami i wiernością chrześcijańskiej wierze:

„Poznajcie, słudzy Boży, zwłaszcza wy, którzy dopiero teraz przystępujecie do Boga, jakie jest stanowisko wiary, jaka przesłanka prawdy, jaki nakaz karności zabrania wam, oprócz innych błędów światowych, również przyjemności widowisk (etiam spectaculorum voluptates). Przypomnijcie sobie to także i wy, którzy już wyznaliście i zaświadczyliście swą wiarę, aby nikt w przyszłości nie zgrzeszył niewiedza, albo nieszczerym udawaniem niewiedzy. Siła bowiem przyjemności jest tak silna (Tanta est enim vis voluptatum), że z niewiedzy czyni sobie okazję, a świadomość tłumaczy obłudnie [...]. Dlatego właśnie pragniemy przede wszystkim wykazać, że nie da się pogodzić takich przyjemności z prawdziwą religijnością ani z rzetelnym posłuszeństwem wobec prawdziwego Boga (hoc cum maxime paramus demonstrare, quemadmodum istaec non competant verae religioni et vero obsequio erga verum Deum)" ${ }^{\prime 1}$.

Nasuwa się pytanie, co Tertulian rozumiał przez ową „przyjemność” (voluptas), zwłaszcza widowisk, którego siła i czar były tak niebezpieczne dla chrześcijan? Co według niego kryło się w tym pojęciu? Otóż wydaje się, że chociaż nasz kartagiński Retor znajdował się w tym względzie pod niemałym wpływie stoików, którzy przez przyjemność rozumieli najogólniej wolność od wszelkich emocji (spiritus sine passione, animus immobilis, tranquillitas, lenitas, quies, pax $)^{20}$, to sam nigdy nie sprecyzował tego pojęcia i nazwę tę odnosił do różnych stanów ${ }^{21}$, które nazywał przyjemnościami; oprócz widowisk najczęściej do seksu oraz jedzenia i picia ${ }^{22}$, a nawet cierpliwości ${ }^{23}$, kłamania $^{24}$,

${ }^{19}$ Tertullianus, De spectaculis 1, 1-4, SCh 332, 74-78, thum. W. Myszor, PSP 5, 79; por. Kessler, Tertullian und das Vergnügen, s. 326.

${ }^{20}$ Por. Tertullianus, De spectaculis 28, 4, SCh 332, 304: „Philosophi quidem hoc nomen [voluptas] quieti et tranquillitati dederunt”; Apologeticum 38, 5; De pallio 5, 4; G. Rauch, Der Einfluss der stoischen Philosophie der Stoa auf die Lehrbildung Tertulliens, Halle 1890; J. Stelzenberger, Die Beziehungen der frühchristlichen Sittenlehre zur Ethik der Stoa, München 1933; K. Deissner, Das Idealbild des stoischen Weisen, Greifswald 1930; R. Bultmann, The stoic ideal oft the wise man, w: Primitive Christianity, trad. R.H. Fuller, New York 1956, 135-145; A. Jagu, Saint Paul et le stö̈cisme, RSR 32 (1958) 225-250; M. Spanneut, Le stö̈cisme des Pères de l'Église, Paris 1957, 233; J. Whittaker, Christianity et morality in the Roman Empire, VigCh 33 (1979) 209-225; C. Moreschini, Tertulliano tra stoicismo e platonismo, w: Kerygma und Logos. Festschrift C. Andresen, Göttingen 1979, 167-179; M. Spanneut, Les normes morales du stoïcism chez les Pères de l'Église, „Studia Moralia” 19 (1981) 153-175; M.L. Colish, The stoic Tradition from Antiquity to the early Middle Ages, vol. 2: Stoicism in Christian Latin thought, Leiden 1985, 9-29; Kessler, Tertullian und das Vergnügen, s. 324.

${ }^{21}$ Por. Kessler, Tertullian und das Vergnügen, s. 324-325.

${ }^{22}$ Por. C. Rambaux, Tertullien face aux morales des trois premiers siècles, Paris 1979, 170-171.

${ }^{23}$ Por. tamże, s. 344-347 (La «voluptas patientiae»).

${ }^{24}$ Por. Tertullianus, Ad nationes I 7, 5; Apologeticum 7, 12. 
czy posiadania dzieci ${ }^{25}$. Pojmował ją dość szeroko i tradycjonalnie jako satysfakcję i radość ze zrealizowania swoich pragnień i zamierzeń ${ }^{26}$. Zamiast je teoretycznie definiować, wolał konkretnie wymieniać pewne fakty, historie, zjawiska i stany, które nazywał „przyjemnościami”, przyjmując przyjemności grzeszne i niezgodne z chrześcijańską wiarą oraz przyjemności godne chrześcijanina (voluptates christianorum) lub „przyjemności zesłane przez Boga” (voluptates a Domino contributae), które prowadzą go do zbawienia, mające m.in. zastapić grzeszne widowiska publiczne, bo „każde z nich jest jednocześnie zgromadzeniem bezbożnych" (omne spectaculum concilium impiorum) ${ }^{27}$; takie właśnie dopuszczał i zalecał św. Paweł Apostoł ${ }^{28}$. Chrześcijanin ma więc według Tertuliana prawo do przyjemności, ale tylko duchowej i takiej, która nie przeszkadza, lecz gwarantuje lub ułatwia mu zbawienie ${ }^{29}$. Kartagiński Retor jest również pierwszym, jak zaznaczaliśmy, chrześcijańskim autorem, który proponuje obszerną listę takich dozwolonych wyznawcom Chrystusa duchowych i zbawiennych przyjemności, w naszym wypadku zastępczych widowisk, odpowiednio do poszczególnych typów widowisk publicznych, a mianowicie:

„Ty wzdychasz za torem wyścigowym, za sceną, za kurzawą i piaskiem. Powiedz mi lepiej: nie możemy żyć bez przyjemności (non possumus vivere sine voluptate)? [...] Skoro zatem sądzisz, że czas obecny masz spędzić na przyjemnościach (delectamentis), to dlaczego jesteś tak niewdzięczny i nie poprzestaniesz na tylu i tak wielkich przyjemnościach, które otrzymałeś od Pana (tales voluptates a Domino contributas)? Ty ich nawet nie dostrzegasz! Bo cóż jest przyjemniejsze od pojednania z Bogiem Ojcem, od objawienia prawdy, od poznania błędów, od łaski odpuszczającej tyle dawnych zbrodni? Czy może być większa przyjemność (maior voluptas) niż obrzydzenie samej przyjemności (voluptatis), niż pogarda całego świata, niż prawdziwa wolność, niż sumienie czyste, pogodne życie i zupełny brak strachu przed śmiercią? 3. A to, że depczesz bogów pogańskich, wypędzasz demony, przyjmujesz pomocne lekarstwa, prosisz o oświecenie, żyjesz dla Boga? Oto są przyjemności, oto są widowiska dla chrześcijan - widowiska święte, wieczne bez opłat (hae voluptates, haec spectacula Christianorum, sancta, perpetua, gratuita) [...]. A jakie zbliża się zaniedługo widowisko (spectaculum in pro-

${ }^{25}$ Por. tenże, Ad uxorem I 5, 1.

${ }^{26}$ Por. tenże, De spectaculis 28,5 , SCh 332,306 : „Hic voluptas ubi et votum”.

${ }^{27}$ Tamże 3, 8, SCh 332, 114, PSP 5, 84.

${ }^{28}$ Por. tamże 28, 5, SCh, 332, 304-306: „Non possumus vivere sine voluptate qui mori cum voluptate debebimus? Nam quod est aliud votum nostrum quam quod et apostoli, exire de saeculo et recipi apud Dominum? Hic voluptas ubi et votum"; zob. Flm 1, 23; Hbr 4, 11.

${ }^{29}$ Por. F. Wagner, Geschichte der Sittlichkeitsbegriffes, Bd. 2: Der Sittlichkeitsbegriff in der Hl. Schrift und in der altchristlichen Ethik, Münster 1931, 194: „Die Lust ist also auch dem Christen erlaubt, aber nur die geistige Lust, die aus dem Besitz des wahren Glaubens quillt und auf Verachtung aller sinnlichen Lust beruht; wenigstens darf er freiwillig nur solche begehren"; Rambaux, Tertullien face aux morales, s. 172. 
ximo) - przyjście Pana, w którego już nikt nie będzie wątpił, dumnego, tryumfującego, oto radość aniołów, oto chwila zmartwychwstających świętych, a potem królestwo sprawiedliwych, oto nowe miasto Jeruzalem! A do tego dochodzą inne widowiska (alia spectacula) - ów dzień ostatniego powszechnego sądu, którego nie spodziewają się poganie, z którego się śmieją, dzień, w którym stary świat i narody jego zostaną spalone przez trawiący wszystko ogień. To będzie wspaniałe widowisko (spectaculi latitudo)! Cóż mam wtedy podziwiać? $\mathrm{Z}$ czego mam się śmiać? $\mathrm{W}$ jakim widoku mam znaleźć pełnię radości i zadowolenia? Może widząc tylu tak potężnych królów, o których słyszało się, że wzięci zostali do nieba, jęczących razem z samym Jowiszem i jego wielbicielami w okropnych ciemnościach? A może patrząc na namiestników, prześladowców imienia Pańskiego smażących się w gorszych płomieniach, niż sami wymyślili we wściekłości przeciw chrześcijanom? I cóż jeszcze? Oto owi przemądrzali filozofowie razem ze swoimi uczniami, którym wmawiali, że nic nie należy do Boga, że nie ma duszy, że dusze do ciał nie powróca, palą się teraz piekącym wstydem! Oto poeci trzęsą się nie przed Radamantusem czy Minosem, ale wbrew oczekiwaniom przed trybunałem Chrystusa. Wtedy trzeba raczej słuchać tragików, rzecz zrozumiała, głośniej wykrzykujących własną niedolę, wtedy raczej należy zwrócić uwagę na komediantów z powodu ognia bardziej skocznych, wtedy trzeba popatrzeć na woźnicę w pełni czerwieni na ognistym wozie. Tam dopiero będą podziwiani atleci, nie w gimnazjonach, ale wysmarowani płomieniami. Ale nawet wtedy nie na nich miałbym ochotę popatrzeć, wtedy chciałbym skierować swój nienasycony wzrok na tych, co szaleli przeciw Panu [...]. Jakiż to pretor, albo konsul, kwestor, albo kapłan urządzi dla ciebie, nawet przy całej swej hojności, takie widowiska, abyś mógł podziwiać taką okazałość, abyś mógł zachwycać się takimi wspaniałościami? [...] Wierzę, że będzie to przyjemniejsze niż cyrk, niż oboje rodzaje sztuk, niż wszelkie wyścigi stadionu"30.

Oto katalog proponowanych przez Tertuliana zastępczych widowisk - przyjemności (voluptates christianorum), które miały zaspokajać pragnienia i cieszyć starożytnych chrześcijan, a mianowicie najpierw: fakt usynowienia i pojednania człowieka z Bogiem przez śmierć Chrystusa, poznanie autentycznej prawdy, poznanie swych błędów, obrzydzenie sobie wszelkich rozkoszy i przyjemności, pogarda dla całego świata, poczucie prawdziwej wolności, posiadanie czystego sumienia, pogoda codziennego życia, brak lęku przed śmiercia, deptanie i obalanie bożków pogańskich, władza wypędzania demonów, władza uzdrawiania, życie dla Boga. Są to, zdaniem naszego Retora, prawdziwe voluptates christianorum - „widowiska święte, wieczne, bez opłat”. Stanowią one, jak widać, pewną sumę dowolnie wybranych abstrakcyjnych prawd i stanów z historii zbawienia chrześcijańskiego, do których można by dołączyć jeszcze

${ }^{30}$ Tertullianus, De spectaculis 28, 5 - 29, 3; 30, 1-5 i 7, SCh 332, 304-312 i 316-328, PSP 5, 111-113. 
wiele innych, (jak np. pełnienie uczynków miłości charytatywnej, które również dostarczają wiele szczęścia i przyjemności), wymagających zastanowienia się i refleksji, które zapewne z trudem mogły zastapić atrakcyjne nawet dla starożytnych chrześcijan widowiska publiczne. Nic też dziwnego, że tego rodzaju zaproponowane po raz pierwszy przez Tertuliana voluptates christianorum nie wzbudziły u jego czytelników i komentatorów szerszego zainteresowania ${ }^{31}$. Dla jednych jest to tylko retoryczne podsumowanie całego traktatu, w którym autor proponuje pewną sumę wymyślonych w oparciu o życie chrześcijańskie dozwolonych przyjemności, odpowiadających zwalczanym niedozwolonym przyjemnościom poszczególnych widowisk publicznych (voluptates spectaculorum $^{32}$, dla innych są to sztuczne i obce życiu w porównaniu z pogańskimi wymyślone przez Tertuliana alternatywne przyjemności ${ }^{33}$. Mimo abstrakcyjności i niewielkiej atrakcyjności zaproponowanych powyżej zastępczych przyjemności widowiskowych kartagiński Retor zachęca swoich chrześcijańskich rodaków do ich oglądania i przeżywania:

„W tych widowiskach masz szukać zabaw cyrkowych (in his tibi ludos circenses), tutaj obserwuj drogi świata, licz czasy mknące, patrz na osiagnięte granice, broń gmin kościelnych, budź się na znak boży, powstań na głos trąby anioła, a chwałę swoją wypatruj w palmie męczeńskiej. Jeśli lubicie treść przedstawień scenicznych (Si scaenicae doctrinae delectant), to mamy dosyć literatury, dosyć wierszy, myśli, a nawet dosyć muzyki i pieśni. To nie bajki, ale prawda, nie powikłane wierszydła, ale pełne prawdziwej prostoty. Pragniesz walk na pięści i zapasów (vis et pugillatus et luctatus), oto są, nawet nie mało, ale bardzo wiele. Patrz na bezwstyd odrzucony przez czystość, na zdradę odciętą od wiary, na okrucieństwa pobite przez miłosierdzie, na rozpustę zwyciężoną przez skromność. Takie to są u nas zapasy (tales sunt

${ }^{31}$ Komentują je nieliczni, m.in. Weisman, Kirche und Schauspiele, s. 107-108; Rambeaux, Tertullien face aux morales, s. 171-172, n. 444; K.W. Weeber, w: Tertullianus, De spectaculis - Über die Schauspiele, Stuttgart 1988, 118, nota 1; obszernie Kessler, Tertullian und das Vergnügen in De spectaculis, s. 330-351; P. Kitzler, w: Tertullianus, De spectaculis - O hrach, Praha 2004, 188-198; zob. też C. Lo Cicero, L'epilogo del De spectaculis di Tertulliano, „Pan” 6 (1978) 65-84; Lugaresi, Il teatro di Dio, s. 417-427 (Spectacula christianorum: le alternative cristiane agli spettacoli).

${ }^{32}$ Por. J. Büchner, w: Q.S.F. Tertullian, De spectaculis, Würzburg 1935, 153; B. Nisters, Tertullian. Persönlichkeit und Schicksal, Münster 1950, 38, nota 4: „Tertullian beschreibt [...] in rhetorischer Weise die Ergötzlichkeiten des Christen"; T.D. Barnes, Tertullian. A historical and literary study, Oxford 1971, 96: „A long passage of fiery eloquence argues that renunciation now will bring far greater pleasure in the future"; Kessler, Tertullian und das Vergnügen, s. 331.

${ }^{33}$ Por. E. Castorina, w: Tertulliani De spectaculis, Firenze 1961, 373, nota 4: „Questa retorica trasposizione dei ludi circenses non era certo la piu adatta a persuadere dei fedeli piu tiepidi"; Schöllgen, Die Teilnahme der Christen am städtischen Leben, s. 29, nota 16: „So sehr sich Tertullian in seiner Schauspielschrift auch bemüht, für die einzelnen Gattungen christliche Pendants aufzuweisen, das große rhetorische Feuerwerk kann über die Künstlichkeit seiner Analogien nicht hinwegtäuschen"; Kessler, Tertulian und das Vergnügen, s. 331. 
apud nos agones), w których my sami zdobywamy zwycięskie wieńce. A jeśli chcesz i krwi trochę - masz krew Chrystusową"34.

O wiele barwniejsze i bardziej działające na wyobraźnię zastępcze widowisko zaproponował Tertulian, jak widać z przytoczonej również wyżej jego wypowiedzi, w wizji powtórnego przyjścia Chrystusa, połączonego ze zmartwychwstaniem sprawiedliwych, sądem ostatecznym i ukaraniem wszystkich niesprawiedliwych, zwłaszcza ze świata pogańskiego. Autor nasz wprost z sadystyczną radością, jak zauważają komentatorowie ${ }^{35}$, umieszcza w piekle smażących się w ogniu pogańskich namiestników i królów, filozofów, poetów, stadionowych woźniców i atletów oraz wszystkich prześladowców chrześcijan. Tu też jako do odpowiedniego miejsca każe przenieść lamenty i dramaturgię wystawianych w teatrach tragedii i komedii ${ }^{36}$. Tego rodzaju widowisko musiało zapewne oddziałać i na wyobraźnię starożytnych chrześcijan oraz pozostawać długo w ich pamięci, a może nawet i zniechęcić z korzystania z publicznych widowiskowych przyjemności. Trudno dziś powiedzieć, czy i jakim stopniu powyższe propozycje Tertuliana wpłynęły na zaspokojenie pragnień żądnych przyjemności widowiskowych starożytnych kartagińskich chrześcijan. Czy one ich przekonały i sprawiły, że zaprzestali, lub przynajmniej ograniczyli, uczęszczać na grzeszne widowiska publiczne? Była to jednak pierwsza próba wskazania przez chrześcijańskiego autora oferowanych przez Boga w dostatecznej ilości zdrowych i zbawiennych przyjemności zastępczych, które tylko należy indywidualnie dostrzegać i kontemplować - cur tam ingratus es ut tot et tales voluptates a Deo contributas tibi satis non habeas neque recognoscas? ${ }^{37}$.

\section{NOWACJAN I CYPRIAN}

Nieco barwniejsze i bardziej oddziałujące na wyobraźnię chrześcijańskie widowiska zastępcze proponował pół wieku później (ok. 247 r.) ${ }^{38}$ rzymski du-

${ }^{34}$ Tertullianus, De spectaculis 29, 3-5, SCh 332, 312-316, PSP 5, 111-112.

${ }^{35}$ Por. H.F. Campenhausen, Lateinische Kirchenväter, Stuttgart 1960, tłum. K. Wierszyłowski, Warszawa 1967, 203: „Tak może pisać tylko Tertulian. Żaden Grek, ale też i żaden chrześcijanin w średniowieczu nie przelał nigdy na papier czegoś tak okrutnie sadystycznego i straszliwie majestatycznego. Nie daje się niczym zachwiać”; J.C. Fredouille, Tertullien et la conversion de la culture antique, Paris 1972, 152, mówi tu o „un frisson inquiétant de sadisme”; Rambeaux, Tertullien face aux morales, s. 183: „Il état difficile, même pour un homme Tertullien, de se libérer du sadisme qu'il reprochait aux spectateurs de l'amphithéatre”; Kessler, Tertullian und das Vergnügen, s. 333.

${ }^{36}$ Por. M.G. Mosci Sassi, Una proposta di lettura a Tert. Spect. 29, 5, „Res Publica Litterarum” 12 (1989) 139-143; E. Peruzzi, Tertulliano, Spect. 29, 5, „La Parola del Passato” 44 (1989) 186-187.

${ }^{37}$ Tertullianus, De spectaculis 29, 1, SCh 332, 306.

${ }^{38}$ Tę konkretną datę powstania traktatu sugerują m.in. H.J. Vogt (Coetus sanctorum. Der Kirchenbegriff des Novatian und die Geschichte seiner Sonderkirche, Bonn 1968, 34) i S. Prete (L'Antico Testamento in Novaziano: De spectaculis 10, „Augustinianum” 22:1982, 231), uzasadniając ją obchodami 1000-lecia założenia Rzymu, organizowanymi przez cesarza Filipa Araba, który urzą- 
chowny Nowacjan, który w specjalnym traktacie De spectaculis ${ }^{39} \mathrm{w}$ formie listu pasterskiego ostrzega pozostających $\mathrm{w}$ oddaleniu wiernych przed niebezpieczeństwami wynikającymi z oglądania widowisk publicznych, zwłaszcza przed propagowaną przez nie idololatrią i niemoralnością; karci ich przy tym, że niektórzy z nich usprawiedliwiają ich oglądanie powagą Pisma Świętego:

„Nie brakuje kuszących zwolenników i pobłażliwych patronów tego występku, którzy udzielają tym grzechom usprawiedliwienia, i co gorsze - powołują się na świadectwo Pism Bożych w obronie tego przestępstwa, jakoby to była niewinna i bezgrzeszna przyjemność z oglądania widowisk, jedynie rozrywka dla umysłu [...] nie szuka się potępienia błędów, lecz w ich obronie powołuje się na autorytet Pisma Świętego [...]. A przecież, kiedy thumy chrześcijan oglądają w teatrze pogańskie przedstawienie na cześć jakiegoś bóstwa, to tym samym bronią bałwochwalstwa i znieważają prawdziwą Bożą religię"*0.

Autor nasz zbija po kolei wszystkie argumenty biblijne, uzasadniające rzekomo dopuszczalność poszczególnych rodzajów widowisk publicznych oraz stwierdza, że chrześcijanie, których w tym traktacie często nazywa „wiernymi" (christiani fideles) dla podkreślenia obowiązującej ich bezkompromisowości wobec zwyczajów pogańskich ${ }^{41}$, warci są lepszych widowisk - godnych swej wiary (spectacula meliora - condigna fidei spectacula), a winni ich szukać nie tylko w pięknie i porządku otaczającego ich świata, ale przede wszystkim w Piśmie Świętym:

„Chrześcijanin, jeśli zechce, ma lepsze widowiska, jeśliby się skupił, ma prawdziwe i pożyteczne przyjemności (Habet christianus spectacula melio$r a$, si velit, habet veras et profuturas voluptates, si se recollegerit). Aby pominąc to, czego jeszcze nie można kontemplować , ma do dyspozycji piękno tego świata, niech go ogląda i podziwia: niech patrzy na wschód słońca, i znowu - na jego zachód, które w kolejnych odstępach wydzielają dnie i noce; na tarczę księżyca wyznaczająca swoim powiększaniem i pomniejszaniem się bieg czasu; na gromady błyskających gwiazd świecących z wysoka w swoim ciagłym ruchu; na cały rok podzielony na następujące po sobie pory i na poszczególne dni z nocami podzielone odstępami godzin; na ogrom ziemi pooranej górami i płynącymi rzekami z niewyczerpanych źródeł; na rozległe morza ze swoimi falami i wybrzeżami z umieszczonym równocześnie w pośrodku powietrzem, pozostającym w swoich granicach i harmonii, ożywiającym wszystko swoją lekkością, już to spuszczając deszcz ze ściśniętych

dził z tej okazji wiele różnego rodzaju bogatych widowisk, uczęszczanych thumnie również przez chrześcijan, na co zareagował właśnie swoim pismem rzymski duszpasterz Nowacjan.

${ }^{39}$ Por. przypis $\mathrm{nr} 2$.

${ }^{40}$ Novatianus, De spectaculis 1, 3 i 2, 2, CCL 4, 167-168. Jeśli przy cytowanym źródle nie podano nazwiska tłumacza, jego przekład pochodzi od autora artykułu.

${ }^{41} \mathrm{Na}$ temat semantycznego znaczenia wyrażenia christianus fidelis u Nowacjana zob. Vogt, Coetus sanctorum, s. 34-35; por. też Prete, L'Antico Testamento in Novaziano, s. 232. 
chmur, już to przywracając pogodę; w tych zaś wszystkich na odpowiednich mieszkańców - w powietrzu na ptaki, w morzu na ryby, a na ziemi na człowieka; Niech te i inne dzieła Boże, mówię, będą widowiskami dla wiernych chrześcijan (Haec, inquam, et alia item opera divina sint christianis fidelibus spectacula). Jaki teatr zbudowany ludzkimi rękami można porównać z tymi dziełami? Choćby był zbudowany z ogromnej ilości kamieni, to i tak szczyty gór są wyższe, i choćby kasetonowe sufity błyszczały złotem, to i tak nie przewyższą blasku gwiazd. Nie będzie nigdy wyrażał podziwu dla dzieł ludzkich ten, kto ma świadomość, że jest dzieckiem Bożym. Kto bowiem wyraża podziw dla czegoś, co nie jest Bogiem, traci zawsze coś ze swej szlachetności. Wierny chrześcijanin, mówię, niech opiera się na Pismach Świętych: w nich będzie szukał odpowiednich dla swej wiary widowisk (Scripturis, inquam, sacris incumbat christianus fidelis: ibi inveniet condigna fidei spectacula). Zobaczy Boga, który stwarza swój świat i ludzi z pozostałymi istotami, oraz udoskonala owe cudowne stworzenia, będzie patrzył na świat ze swoimi grzechami, na sprawiedliwie zsyłane nieszczęścia, na nagradzanie uczciwych i karanie bezbożników, na osuszane morza dla ludu Bożego i ponownie ze skały wyprowadzane wody dla tegoż ludu. Będzie oglądał zsyłane z nieba urodzajne zbiory bez używania pługa i klepisk. Będzie patrzył na rzeki użyczające suchych przejść wstrzymawszy wcześniej nawał wód. Będzie patrzył na wiarę pewnych ludzi walczącą z ogniem oraz na dzikie zwierzęta pokonane i oswojone wiarą. Będzie oglądał nawet dusze ze samej śmierci odwoływane, a także jak ciała już w rozkładzie powstają z grobów i przedziwnie wracają do nowego życia. A oprócz tych wszystkich zobaczy jeszcze jedno większe widowisko (maius videbit spectaculum): samego diabła, który choć zatryumfował nad całym światem, leży teraz powalony pod stopami Chrystusa. Bracia, co to za wspaniałe widowisko (quam hoc decorum spectaculum), jakże radosne, a jakże konieczne: mieć zawsze nadzieję i otwarte oczy na własne zbawienie. Jest to widowisko, które można oglądać nawet po utracie wzroku, jest to widowisko, którego nie organizuje ani pretor (Hoc est spectaculum quod videtur etiam luminibus amissis, hoc est spectaculum quod non exhibet praetor) ani konsul, lecz tylko Ten, który jest jedyny, przed wszystkim i ponad wszystko i z którego wszystko - Ojciec naszego Pana Jezusa Chrystusa, któremu cześć i chwała na wieki wieków" ${ }^{2}$.

Nowacjan, jak widać, podobnie jak Tertulian, nazywał niekiedy widowiska „przyjemnościami” (voluptates) ${ }^{43}$ oraz tak jak i on w ostatnich rozdziałach swego traktatu De spectaculis (9-10) zaproponował gamę alternatywnych widowisk chrześcijańskich niejako w dwóch odsłonach teatralnych: najpierw idąc za tradycją stoicką ${ }^{44}$ zachęca do podziwiania piękna i porządku świata widzialnego

\footnotetext{
${ }^{42}$ Novatianus, De spectaculis 9-10, CCL 4, 177-179, por. Lugaresi, Il teatro di Dio, s. 437.

${ }^{43}$ Por. Novatianus, De spectaculis 1,$3 ; 4,2 ; 4,3 ; 4,4 ; 4,5 ; 5,1 ; 5,5 ; 9,1$.

${ }^{44}$ Por. Spanneut, Le stoïcisme des Pères de l'Église, s. 375-376, 384 i 411-412; o jego podziwie
} 
oraz jego zjawisk naturalnych: wschodu i zachodu słońca oddzielającego regularnie dnie i noce, ruchu i zmian księżyca wyznaczającego bieg czasu, ciągłego ruchu błyskających gwiazd, roku dzielącego się regularnie na pory oraz na dnie i godziny, ziemi pooranej górami i rzekami zasilanymi nieustannie wodą z niewyczerpanych źródeł, przestrzeni morskich oddzielonych od nieba stałą ilością powietrza ożywiającego wszystko oraz spuszczającego deszcze i regulującego pogodę, a wreszcie samych mieszkańców ziemi: na lądzie - ludzi, w morzu ryb, a w powietrzu ptaków. Wszystkim tym spektakularnym i godnym podziwu zjawiskom naturalnym Autor nasz nadaje jednak charakter chrześcijański ${ }^{45}$, podkreślając, że są to dzieła Boże (opera divina), będące odpowiednimi widowiskami dla chrześcijan. One to razem wzięte stanowią dla nich odpowiedni teatr, z którym nie może się równać żadna inna, zbudowana nawet z największym przepychem przez pretora czy konsula kamienna budowla teatralna, prawdziwy zaś wyznawca Chrystusa, będący dzieckiem Bożym nie może podziwiać czegoś, co nie pochodzi od Boga. Przejawia się tu jednak stoickie spojrzenie na wszechświat, które oddziaływało mocno nie tylko na wczesnochrześcijańskich autorów afrykańskich (Tertuliana, Minucjusza Feliksa ${ }^{46}$, św. Cypriana), ale również na rzymskich, podkreślające piękno, różnorodność, porządek i harmonię wszechświata, Nowacjan zaś, choć niezupełnie go podzielał (ulegał jednak wpływowi Pliniusza Młodszego, nawet językowo ${ }^{47}$, to jednak go po chrześcijańsku podzielał, przyjmując chrześcijańskie pojęcie Boga, który stwarza, rządzi, modyfikuje i udoskonala wychodzące z Jego rąk stworzenia przez historię zbawienia (admirabilem Dei fabricam melioremque facientem, 10, 1).

W drugiej odsłonie (10, 1-3) Nowacjan, podobnie jak Tertulian $(29,4)$, przypomina, że wierny chrześcijanin powinien się trzymać Pisma Świętego i w nim przede wszystkim szukać odpowiednich dla swej wiary widowisk, opartych na prawdzie, a nie jak w teatrze na bajkach i mitach (nec fabulae sed veritates); wymienia przy tym szczegółowo cała gamę scen i wydarzeń biblijnych, głównie ze Starego Testamentu (począwszy od pierwszych jego stron),

dla piękna świata stworzonego zob. J. Daniélou, Le origini del cristianesimo latino. Storia delle dottrine cristiane prima di Nicea, Bologna 1991, 223-233; Novatianus, De Trinitate 1, 1-8; 8, 1.

${ }^{45}$ Por. Saggioro, Introduzione, traduzione e commento, w: Novaziano, Gli spettacoli, s. 103-104.

${ }^{46}$ Por. Minucius Felix, Octavius 17-18, spec. 17, 5-6 i 9, ed. C. Halm, CSEL 2, Vindobonae 1867, 101-102, tłum. M. Szarmach, PSP 44, Warszawa 1988, 39-40: „Spójrz tylko na niebo! Jak szeroko się ono rozciąga, jak szybko zmienia się jego obraz, bo w nocy jest wyiskrzone gwiazdami, za dnia zaś zalane słońcem [...]. Spójrz na rok, jak bieg słońca czas jego wyznacza, spójrz na miesiąc, jak księżyc pełnią i nowiem go odmierza. Czyż mam wspominać o stałej przemienności dnia i nocy, abyśmy mieli czas i na pracę i na odpoczynek? [...]. Przypatrz się morzu, jak granice jego wyznacza wybrzeże. Patrz na drzewa, jak żywią się sokami ziemi. Spójrz na ocean, jak przypływa i odpływa. Patrz na źródła, jak wytryskują z odwiecznych żył wodnych. Przypatrz się rzekom, jak płyną stale tym samym wyżłobionym przez siebie korytem. Cóż będę mówił o wzniosłych szczytach gór, o zboczach pagórków i o rozciagających się równinach?"

${ }^{47}$ Por. H. Koch, Novaziano, Cipriano e Plinio il Giovane, „Religio” 11 (1935) 321-325; Prete, L'Antico Testamento in Novaziano, s. 235, n. 19 (przykłady). 
które za takowe mogą uchodzić, a mianowicie: stwarzanie przez Boga świata oraz zwierząt i ludzi (Rdz 1, 1 - 2, 7), udoskonalanie stworzonego świata ( $R d z$ 1,31 ), nagradzanie sprawiedliwych i karanie bezbożnych przez potop (Rdz 6, 5-8; 7, 21-23), osuszenie Morza Czerwonego dla przejścia wędrującego ludu wybranego (Wj 14, 21-22), cudowne wyprowadzenie wody ze skały przez Mojżesza dla wędrujących przez pustynię Izraelitów (Wj 17, 6), zsyłanie chleba (manny) z nieba bez konieczności uprawiania roli i młócenia zboża (Wj 16, 4, 14-15), przejście Izraelitów z arką przez Jordan po zatrzymaniu się jego wód (Joz 3, 15-17), uratowanie wierzących w ocalenie trzech młodzieńców wrzuconych do rozpalonego pieca przez Nabuchodonozora (Dn 3, 20-24), ocalenie ufającego Bogu Daniela wrzuconego do jaskini lwów przez króla Dariusza (Dn $6,17-23$; 1Mch 2, 60), wskrzeszenie zmarłego syna wdowy przez proroka Elizeusza (2Krl 4, 34-35), ożywienie wysuszonych kości przez proroka Ezechiela (Ez 37, 1-14) i wychodzenie umarłych z grobów po śmierci Chrystusa na Golgocie (Mt 27, 52-53), a przede wszystkim powalenie diabła pod stopy tryumfującego Chrystusa. Nie trudno zauważyć, że jest to wybór mniej lub więcej malowniczych i dramatycznych scen i wydarzeń, zaczerpniętych głównie z Biblii Starego Testamentu, pochodzących m.in. z przedchrzcielnej katechezy chrześcijańskiej, często prezentowanych w ikonografii katakumbo$w^{j 48}$, stanowiących swego rodzaju, jak to nazwał S. Prete, ,breve filmato biblico", złożony z kilkunastu barwnych i dramatycznych obrazów ${ }^{49}$. Przez tego rodzaju wybrane obrazy Nowacjan chciał zapewne obudzić wiarę chrześcijan we wszechmogącego Boga, jako prawdziwego aktora i sprawcę tych wielkich wydarzeń, Pana życia, śmierci i całej historii ludzkiej od upadku do zbawienia. To one, zdaniem Nowacjana, mają stanowić odpowiednie dla chrześcijan, oparte na prawdzie, widowiska - spectacula Christiana.

Porównując teraz treści ostatnich rozdziałów traktatów De spectaculis Tertuliana i Nowacjana, proponujących alternatywne widowiska dla chrześcijan zamiast publicznych pogańskich, zauważamy niemałe w nich różnice. Najpierw Tertulian, w przeciwieństwie do Nowacjana, mimo iż znajdował się, jak zaznaczaliśmy, pod dużym wpływem stoików, to nie proponował wprost, jak oni i ten drugi, podziwiania piękna i zjawisk otaczającej natury, wśród alternatywnych widowisk dla chrześcijan. Nowacjan natomiast, w przeciwieństwie do Tertuliana, wśród tych alternatywnych widowisk ogranicza się tylko do przedstawień teatralnych, pomijając zupełnie widowiska amfiteatralne i cyrkowe, mimo iż jako Rzymianin zapewne dobrze je znał, a w swoim traktacie potępiał ich oglądanie. Autorzy ci różnią się także w samym sposobie prezen-

${ }^{48}$ Zob. np. malowidła w Capella Greca w katakumbach św. Pryscylli: cud wyprowadzenia wody ze skały, trzej młodzieńcy w piecu ognistym, Daniel w jaskini lwów, por. P. Testini, Archeologia cristiana, Roma 1958, 256; Lexicon der christlichen Ikonographie, Freiburg 1968-1972, Bd. I 469-473 (Daniel), II 464-466 (potop).

${ }^{49}$ Por. Prete, L'Antico Testamento in Novaziano, s. 232-233; Saggioro, Introduzione, traduzione e commento, w: Novaziano, Gli spettacoli, s. 105. 
towania alternatywnych widowisk teatralnych, głównie prawd religijnych i zastępczych obrazów biblijnych. Chodzi tu głównie o interpretację ich przedstawienia sądu ostatecznego: Tertulian ukazuje ten sąd jako chwilę tryumfalnego, ale $\mathrm{z}$ chęcią pomszczenia i sarkastycznego zadowolenia, ukarania wszystkich prześladowców, wrogów i przeciwników chrześcijaństwa (pogańskich królów, filozofów i poetów, aktorów teatralnych i tancerzy, woźniców i atletów oraz Żydów), Nowacjan natomiast przedstawia sąd ostateczny w spokojnej wizji pozytywnej, niemal bukolicznej, utrzymanej w optyce chrześcijańskiego darowania i odpuszczenia grzechów, ukazując tryumf Chrystusa nad szatanem w widowisku światła, piękna i radości (quam hoc decorum spectaculum, quam iocundum, 10, 3), to zaś przezwyciężenie pragnienia zemsty stanowi jeden $\mathrm{z}$ istotnych elementów oryginalności tego drugiego ${ }^{50}$. Ponadto Kartagińczyk kieruje przy tym myśl swoich adresatów do osób trzecich - winnych ukarania, Rzymianin zaś jako duszpasterz zawsze do nadziei własnego zbawienia (Intueri semper spem suam et oculos aperire ad salutem suam, 10, 3).

Podobnie 50 lat później do oglądania darmowych Bożych widowisk, zamiast kosztownych, urządzanych przez prokonsulów i cesarzy, zachęcał w afrykańskiej Kartaginie biskup św. Cyprian († 258). Czynił to w swoim piśmie De opere et eleemosynis z 252 r., zachęcając swych zdziesiątkowanych przez zarazę, ale nadal żądnych wszelkich widowisk wiernych, do wspomagania się wzajemnie, oszczędzania i świadczenia jałmużny:

„Jakież to igrzyska (Quale munus est), najdrożsi Bracia, które się odbywają na oczach Boga! Jeżeli w publicznych igrzyskach pogan (si in gentilium munere) wielką i chwalebną wydaje się rzeczą że są na nich obecni prokonsulowie i imperatorowie, a przygotowania i wydatki urządzających są większe, by mogli przypodobać się przełożonym, to o ileż nad to piękniejszą i większą jest chwała Boga i Chrystusa mieć jako widzów, o ileż tu i przygotowania gruntowniejszego i hojniejszych trzeba wydatków, gdzie na widowisko (ad spectaculum) schodzą się moce aniołów, schodzą się wszyscy aniołowie, gdzie urządzający nie o kwadrygę lub o konsulat się ubiega, lecz otrzymuje żywot wieczny, gdzie nie chodzi o zjednanie czczych i przemijających względów tłumu, lecz o otrzymanie wiekuistej nagrody królestwa niebieskiego"s1.

Chwała Boża zatem, której jednak św. Cyprian bliżej nie charakteryzuje, jest owym zastępującym pogańskie, publiczne i kosztowne igrzyska, odpowiednim dla chrześcijan widowiskiem, jego zaś widzami obok nich są wszystkie zastępy aniołów, a nagrodą za jego oglądanie nie jest pozyskiwanie doczesnych zaszczytów i względów ludzkich, ale zbawienie i szczęście wieczne.

${ }^{50}$ Por. Prete, L'Antico Testamento in Novaziano, s. 231; Saggioro, Introduzione, traduzione e commento, w: Novaziano, Gli spettacoli, s. 106-107.

${ }^{51}$ Cyprianus, De opere et eleemosynis 21, ed. M. Simonetti, CCL 3A, Turnhout 1976, 68, thum. J. Czuj, POK 19, Poznań 1937, 342 (przekład poprawiony przez autora artykułu). 


\section{JAN CHRYZOSTOM}

Największym jednak chyba wczesnochrześcijańskim protagonistą i przeciwnikiem wszelkich publicznych widowisk był św. Jan Chryzostom († 407). Będąc biskupem stolicy cesarstwa Konstantynopola, a wcześniej rodakiem i wybitnym mówcą Antiochii, znał dobrze ich negatywne przejawy i skutki. Jako doświadczony duszpasterz zdawał sobie jednak i on sprawę, że samo ich zakazywanie pasjonującym się nimi wiernym nie wystarczy, ale należy je zastąpić czymś pozytywnym i chrześcijańskim, stąd też w jego pismach wiele różnorodnych propozycji mających zastąpić widowiska publiczne. Oryginalną ich cechą były m.in. częste zachęty, by od małego odzwyczajać dzieci od oglądania wszelkich widowisk publicznych, ukazując ich niemoralny charakter i szkodliwośćc ${ }^{52}$ oraz proponując podziwianie innych pięknych rzeczy:

„Baczmy na to, aby syn nie patrzył i nie przysłuchiwał się niczemu nieprzyzwoitemu, nie powinien też syn wolny uczęszczać do teatru. Jeśli bowiem okazuje zamiłowanie do widowisk, wskaż mu na innych towarzyszy wieku, którzy do teatru nie chodzą. Ich przykład zachęci go do gorliwości [...]. W zamian za widowiska teatralne opowiedz mu wesołą historię, pokaż mu miłe krajobrazy lub piękne budowle miasta. Potem powiedz do niego: «Mój synu, wolnym nie wypada chodzić do teatru - te widowiska są dobre dla niewolników, gdzie występują obnażone kobiety i gdzie się prowadzi bezwstydne rozmowy. Wiedz, że gdyby tam nic się nie słyszało i nie widziało nic nieprzyzwoitego, można by tam pójść. Ale tam słyszy się tylko nieprzyzwoite mowy, a to, co się tam dzieje, niegodne jest twych oczu». Po tych słowach uściskaj go, by odczuł twą miłość [...]. Wieczorem ojciec niech weźmie syna i pokaże mu wracających z teatru, niech wykpi starych, że są głupsi od młodych, niech wyśmieje młodych rozpalonych w nieskromnej rozkoszy. Niech zapyta syna: "Co zyskali ci ludzie? - nic innego, tylko wstyd pośmiewisko i wzgardę»" ${ }^{3}$.

Wszelkie widowiska publiczne w takich metropoliach, jak Rzym, Konstantynopol czy Antiochia były zwyczajnymi i świadomie wybieranymi przyjemnościami i rozrywkami obywateli. Nasz Duszpasterz apeluje do sumienia i woli swoich wiernych, by wybierali takie, które nie przynoszą szkody ich duszy i zgodne są z zasadami chrześcijańskimi, proponując przy tym konkretnie między innymi, podobnie jak to czynili stoicy, dostrzeganie i podziwianie

${ }^{52}$ Por. Longosz, Widowiska teatralne zagrożeniem dla życia rodzinnego, s. 135-198 (tekst + obszerna antologia tekstów).

${ }^{53}$ Joannes Chrysostomus, De inani gloria et de educandis liberis 77-79, éd. A.-M. Malingrey, SCh 188, Paris 1972, 178-184, thum. W. Kania, BOK 19, Kraków 2002, 99-100; tamże 59, SCh 188, 156-158, BOK 19, 94: „W tym względzie wychowawca i służący powinni szczególnie pilnie uważać. Wskazywać mu piękne przedmioty, aby jego oczy odwrócić od złych rzeczy, wskazać na niebo i gwiazdy, na ziemię i jej kwiaty, na łąki i obrazki - niech tymi rzeczami zachwycają się jego oczy; tyle bowiem jest piękna, które nie przynosi żadnej szkody”. 
piękna natury, czy własnej rodziny; to oni sami jako obywatele niebios powinni je odpowiednio dobierać:

„Powie ktoś, usuńmy więc sceny! Oby je można było usunąć, ale jeśli zechcecie, to z waszej woli już dawno byłyby usunięte i zburzone. Jednakże ja niczego takiego nie wymagam, stojące zostawcie puste, co zasługuje na większą pochwałę niż zburzenie. Naśladujcie przynajmniej barbarzyńców, jeśli już nie kogoś innego: oni nie mają żadnego sprośnego widowiska. Czyż więc będziemy mieli w przyszłości jakieś usprawiedliwienie, jeśli my, obywatele niebios, należący do jednego chóru z cherubinami, jesteśmy pod tym względem gorsi od barbarzyńców, i to wtedy, gdy wolno nam wymyślać sobie tysiące innych rozrywek lepszych niż te? Jeśli chcesz rozerwać umysł, chodź do ogrodów, nad rzekę, nad stawy; przypatruj się sadom, przysłuchuj się cykającym świerszczom, odwiedzaj groby męczenników, gdzie jest uzdrowienie dla ciała i pożytek dla duszy, gdzie nie ma po radości żadnego żalu ani szkody, tak jak tutaj. Masz żonę, masz dzieci; cóż równego tej przyjemności? Masz dom, masz przyjaciół: to są przyjemności, które oprócz skromności mają w sobie wielki zysk. Powiedz mi, cóż milszego niż dzieci? Cóż milszego niż żona dla człowieka chcącego żyć w czystości? Powiadają, że pewnego razu barbarzyńcy wypowiedzieli zdanie pełne głębokich myśli: słysząc o tych niegodziwych teatrach i o tej nieprzyzwoitej rozrywce, powiedzieli: «Rzymianie wymyślili sobie takie rozrywki, jakby nie mieli żon ani dzieci», wskazując tym samym, że nie ma nic milszego nad żonę i dzieci, jeśli chcesz żyć uczciwie" 54 .

Złotousty Kaznodzieja, jak widać, nie tylko proponuje zastępcze pozytywne widowiska i rozrywki, ale dla przekonania do nich swych słuchaczy ukazuje również konkretne wynikające z nich korzyści oraz szkody z niemoralnych, zwłaszcza teatralnych przedstawień; czyni to zaś porównując owoce śpiewów w teatrze i u mnichów na pustyni, do których odwiedzenia i posłuchania zachęca swych wiernych:

„Gdzie są teraz ci, którzy udają się na diabelskie chóry i nierządne śpiewy, którzy przesiadują w teatrach? Wstydzę się o nich wspominać, lecz muszę to uczynić z powodu waszej słabości [...]. Porównajmy i my pod względem przyjemności - z powodu której tak wielu spośród lekkomyślnych młodzieńców wpada w nierządne sidła - chór na scenie złożony z nierządnych kobiet i nieprzyzwoitych młodzieńców z chórem owych błogosławionych mnichów. Znajdziemy tak wielką różnicę, jakby ktoś słuchał aniołów śpiewających w niebie owe wdzięczne pienia oraz wycia i kwiczenia psów lub świń na kupie gnoju. Przez usta jednych przemawia Chrystus, natomiast język drugich należy do diabła. Tym ostatnim towarzyszą piszczałki z nieprzyjemnym głosem i przykrym widokiem, gdyż ich policzki są nadęte a żyły nabrzmiałe. Pośród zaś tych

${ }^{54}$ Tenże, In Matthaeum hom. 37, 7, PG 57, 428, tłum. J. Krystyniacki, ŹMT 18, Kraków 2000, 439-440. 
poprzednich rozbrzmiewa łaska Ducha Świętego, która zamiast fletni, cytry i piszczałki posługuje się ustami świętych. Cokolwiek byśmy powiedzieli, nie da się opisać owej rozkoszy ludziom przykutym do gliny i wyrabiania cegieł. Dlatego chciałbym wziąć któregoś z tych, którzy popadli w to szaleństwo, i zaprowadzić tam, aby zobaczył chór tych świętych, a nie potrzebowałbym mówić więcej [...]. Nic natomiast podobnego nie zdarza się u mnichów, a raczej wszystko jest na odwrót [...]. Gdy w teatrze widzowie zobaczą nierządnicę przybraną w złociste szaty, człowiek ubogi westchnie i poczuje żal, widząc, że jego żona nie ma nic podobnego. Bogacze natomiast po tym widowisku będą pogardzać swoimi żonami i je lekceważyć. Gdy tamta przedstawia widzom suknie, spojrzenie, głos, chód, zgoła wszystko jako pełne wystawności, wracają roznamiętnieni i wchodzą do własnych domów już jako ludzie zniewoleni. Stąd zniewagi i niesława, stąd nieprzyjaźń, kłótnie i codzienne śmiertelne wypadki. Dlatego życie staje się dla tych, którzy popadli w tę niewolę, nieznośne, żona niemiła, dzieci nie tak kochane, jak dawniej; w domu wszelki porządek zostaje wywrócony do góry nogami, tak że wydaje się, iż nawet światło słoneczne takiego gniewa. $Z$ owych natomiast anielskich chórów nie wynosi się takiego niezadowolenia, ale żona powita męża spokojnego i łagodnego, wolnego od wszelkiej bezecnej namiętności, i stwierdzi, że jest łatwiejszy w obejściu, niż przedtem. Takie właśnie nieszczęścia sprowadza tamten chór, a takie dobrodziejstwa ten. Tamten z owiec czyni wilki, a ten przemienia wilki w jagnięta. Nie powiedzieliśmy jeszcze dotąd nic o samej przyjemności. Bo cóż może być bardziej przyjemnego niż to, że duszy nie gryzie niepokój ani boleść, że się nie smuci ani nie boleje? Rozważmy więc dalej przyjemność obydwóch śpiewów i widowisk. Zobaczmy, że jedna trwa aż do wieczora, dopóki widz siedzi w teatrze, a potem bodzie go gorzej, niż jakikolwiek oścień. Druga zaś utrzymuje się stale w duszy widzów w swej sile. Bo również widok mężów, piękno okolicy, czystość obyczajów, miłe obejście, wdzięk najpiękniejszego uduchowionego śpiewu pozostają zawsze w ich pamięci"s5.

Nie trudno zauważyć, że Jan Chryzostom potępiał również zdecydowanie, podobnie jak ogół Ojców Kościoła, wszelkie tańce i muzykę instrumentalną ${ }^{56}$, które jako pochodne teatralne nazywa często szatańskimi lub rozpustnymi, bo miały rozbudzać namiętności i prowadzić do rozpusty. Przypomina przy tym swoim wiernym, że Bóg dał człowiekowi poszczególne części ciała nie po to, by nimi grzeszył, ale by ich używał dla pożytku w życiu:

„Gdzie jest taniec, tam i diabeł. Bo nie po to Bóg dał nam nogi, byśmy tańczyli, lecz byśmy chodzili prosto. Nie po to, byśmy zachowywali się nieprzyzwoicie, nie po to, byśmy podskakiwali, jak wielbłądy (bo nawet one tańcząc), przed-

${ }_{55}^{5}$ Tamże 68, 4, PG 58, 644-646, ŹMT 23, 318-320.

${ }^{56}$ Por. C. Andersen, Altchristliche Kritik am Tanz. Ein Ausschnitt aus dem Kampf der Alten Kirche gegen heidnische Sitte, ZKG 72 (1961) 217-262; S. Longosz, Muzyka instrumentalna w ocenie wczesnochrześcijańskich pisarzy, w: Musica Antiqua, VI, Bydgoszcz 1982, 355-388. 
stawiają niemiły widok, a cóż dopiero kobiety, lecz abyśmy brali udział w chórach aniołów. Jeśli taki nieprzyzwoity taniec szpeci ciało, to tym bardziej duszę. Takie tańce wyprawiają demony, w taki sposób podskakują tylko ich słudzy"57.

Z czasem jednak i Chryzostom, podobnie jak wielu późniejszych Ojców Kościoła, zaczął w swoich pismach i mowach wprowadzać słownictwo, wyrażenia i porównania również ze świata widowisk, teatru i muzyki, nadając im treść biblijną lub chrześcijańską. Naśladował w tym względzie zapewne św. Pawła, który swoje życie porównywał do zapasów lub do biegu w zawodach na stadionie, gdzie za zwycięstwo otrzymuje się wieniec wręczany przez sędziego (2Tm 4, 7-8; 1 Kor 9, 24-26; Dz 20, 24). Potem przed Janem czynił to także m.in. św. Bazyli Wielki ${ }^{58}$. Cały świat Złotousty nazywał niekiedy wielkim „Bożym teatrem” oraz mówił o przedstawieniach ,teatru duchowego” lub „stadionu duchowego", które przeciwstawiał widowiskom teatrów i stadionów ziemskich, a do oglądania pierwszych zachęcał swoich wiernych ${ }^{59}$. W swoich biblijnych homiliach, które również nierzadko nazywał duchowymi przedstawieniami, wprowadzał często, zapewne pod wpływem stoickiej diatryby, dramatyczne dialogi czy teatralne lub stadionowe metafory i porównania ${ }^{60}$. Teatrem duchowym nazywał nasz Złotousty zarówno różnego rodzaju chrześcijańskie imprezy religijne, jak np. publiczne komentowanie Pisma Świętego ${ }^{61}$, do odwiedzenia, słuchania i oglądania którego zachęcał swych adresatów, jak i niebo i jego mieszkańców:

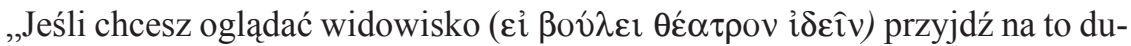

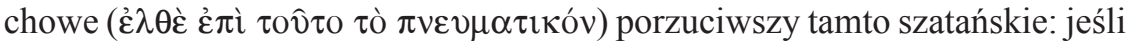
chcesz posłuchać liry, porzuć tamtą muzykę podniecającą ducha, a przyjdź na tą, która uwzniośla twą duszę i umacnia twój umysł. Zobacz, jak różne tony i różne chordy oddają Bogu Najwyższemu Stwórcy jedną i bardzo przyjemną muzykę"62.

${ }^{57}$ Joannes Chrysostomus, In Matthaeum hom. 48, 3, PG 58, 491, ŹMT 23, 82.

${ }^{58}$ Por. Basilius Caesariensis, De Spiritu Sancto 15, 35, éd. B. Pruche, SCh 17bis, Paris 1968, 366, tłum. LG II 340-341: „Jeśli bowiem ci, co osiągają w zawodach graniczną linię stadionu i zawracają z powrotem, muszą na chwilę przystanąć, aby rozpocząć bieg w odwrotnym kierunku, tak wydaje się rzeczą konieczna, by i przy zmianie życia między starym a nowym istnieniem pośredniczyła śmierć, która kładzie kres temu, co ustępuje i daje początek temu, co następuje"; por. thum. A. Brzóstkowska: Św. Bazyli, O Duchu Świętym, Warszawa 1999, 130.

${ }^{59}$ Por. Pasquato, Gli spettacoli in S. Giovanni Crisostomo, s. 325-334; Lugaresi, Il teatro di Dio, s. 799-807 (Spectacula christianorum), spec. s. 805-807 (Alternative dei cristiani agli spettacoli).

${ }^{60}$ Por. Pasquato, Gli spettacoli in S. Giovanni Crisostomo, s. 359-362; J.A. Sawhill, The use of atletic metaphors in the biblical homilies of St. J. Chrysostom, Princeton 1928.

${ }^{61}$ Joannes Chrysostomus, In illud: „Vidi Dominum” hom. 5, 1, PG 56, 130: „Aby dla was jaśniejsze było to, o czym będzie teraz mowa, trzeba powtórzyć parę rzeczy z tego, co niedawno

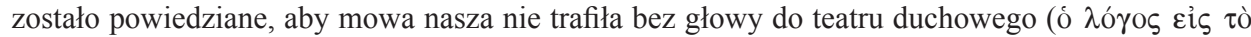

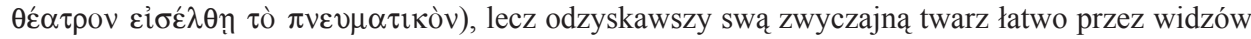

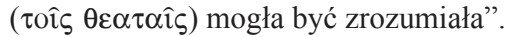

${ }^{62}$ Tenże, In illud Isaiae dictum: „Ego Dominus Deus feci lumen” 1, PG 56, 143. 
„Także ty masz swój teatr [...] a co jest twoim teatrem? - niebo i chóry aniołów: nie mówię tylko o chórach dziewic w niebie, ale i o tych w świecie. Każdy, kto wierzy w Chrystusa, ma ów teatr" ${ }^{93}$.

Jan Chryzostom wielokrotnie w swoich homiliach starał się odwieść swoich słuchaczy od widowisk ziemskich, a kierować ich myśli i pragnienia ku widowiskom boskim i duchowym. Rozpoczynając komentowanie Ewangelii św. Jana, które również traktował jako duchowe widowisko, stara się najpierw w obrazowy i detaliczny sposób wytworzyć atmosferę wielkiego i tłumnego widowiska cyrkowego, stadionowego lub teatralnego, w którym ma wystapić znany woźnica, słynny muzyk lub wybitny retor. Głównym aktorem tego zapowiadanego widowiska jest sam apostoł Jan Ewangelista, syn grzmotu, umiłowany uczeń Chrystusa, kolumna wszystkich Kościołów, który nie będzie recytował $\mathrm{w}$ teatralnym stroju jakiegoś mitycznego dramatu, ale w imieniu Mistrza będzie głosił jedynie prawdę. Ukazuje przy tym konkretne przeciwstawne owoce i skutki działalności aktorów tamtych widowisk i tego duchowego, zachęcając wszystkich do uważnego uczestniczenia w tym drugim:

„Jeżeli widzowie lub słuchacze z tak wielką uwagą siedzą, słuchają i oglądają retorów, flecistów i atletów, to ileż wysiłku i jakiej staranności wy powinniście dołożyć, gdy już nie jakiś flecista czy sofista, ale mąż [Jan] wydający

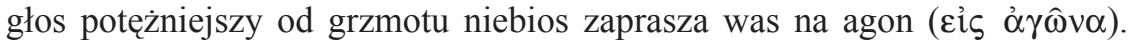
Cały bowiem świat tym wołaniem napełnił i ogarnął napełnił zaś nie wielkością wołania, ale językiem mówiącym z poruszenia Bożej łaski. I to co dziwniejsze, owo wielkie wołanie nie jest ostre ani cierpkie, lecz przyjemniejsze od każdej harmonii muzycznej i bardziej pożądane, posiadając wielką siłę przekonywania; jest ponadto bardzo święte, budzące trwogę, pełne tajemnic i tak dobroczynne, że którzy uważnie je akceptują i realizuja, nie są już ludźmi i nie pozostają już na ziemi, ale wznoszą się ponad wszystkie sprawy światowe i jakby aniołowie zamieszkują ziemię podobnie jak niebo. Ów bowiem syn gromu (Mk 3, 17), umiłowany Chrystusa, kolumna wszystkich Kościołów na świecie, który ma klucze do nieba, który pił z kielicha Chrystusa, który był ochrzczony Jego chrztem, który z wielką ufnością spoczywał na piersi Pana, tu do nas przybywa; i nie będzie odgrywał jakiegoś dramatu (ov̉ $\delta \rho \hat{\alpha} \mu \alpha$ i $\pi$ okpıvó $\mu \varepsilon v o \varsigma)$, nie występuje z głową ubraną w maskę

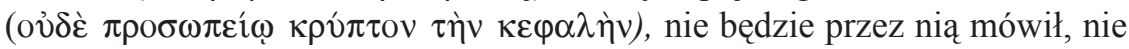

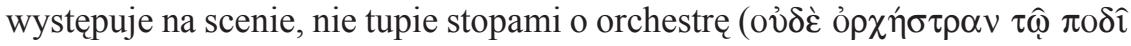
$\kappa \alpha \tau \alpha \kappa \rho о v ́ \omega v)$, nie jest ubrany w złote szaty, lecz wkracza w stroju szczególnej piękności: ukazuje się nam ubrany w samego Chrystusa (Ga 3, 27), mając na nogach obuwie dostosowane do przepowiadania Ewangelii pokoju (Rz 10,15); pas okrywający nie pierś, lecz lędźwie, nie z czerwonej skóry i nie zdobiony w górnej części złotem, lecz utkany i nasączony samą prawdą. Taki to [aktor] prezentuje się nam teraz bez maski: nie ma u niego żadnego

${ }^{63}$ Tenże, In epistulam ad Hebraeos hom. 28, 5, PG 63, 199. 


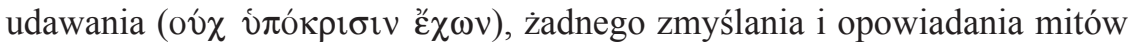

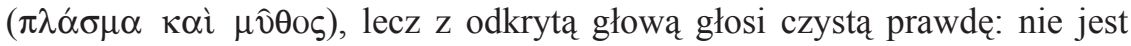
inny w rzeczywistości a inny w przebraniu, by gestem, wzrokiem czy głosem $(\tau \hat{\omega} \sigma \chi \eta \dot{\mu} \mu \alpha \tau \iota, \tau \hat{\omega} \beta \lambda \varepsilon \dot{\varepsilon} \mu \mu \alpha \tau \imath, \tau \hat{̣} \varphi \omega v \hat{)})$ przypodobać się słuchaczom. Do jej przepowiadania nie potrzebuje żadnych instrumentów, ani cytry ani liry, ani innego z nich, ale czyni to językiem, wydając głos przyjemniejszy i użyteczniejszy od jakiejkolwiek cytry lub muzyki. Sceną dla niego jest całe niebo, teatrem - świat, widzami i słuchaczami - wszyscy aniołowie, a spośród ludzi ci, którzy są aniołami lub pragną się nimi stać: ci bowiem tylko mogą dokładnie uchwycić uszami tę harmonię, poświadczyć ją czynami oraz stać się odpowiednimi słuchaczami [...]. Przy tym Apostole stoją najwyższe Moce, podziwiając piękno jego duszy, roztropność i ten rodzaj cnoty, którą ujął samego Chrystusa i otrzymał duchową łaskę"64.

Tym barwnie zaprezentowanym na wstępie duchowym przedstawieniem, opisanym detalicznym, widowiskowym i teatralnym językiem, stara się nasz Duszpasterz zachwycić i zainteresować swoich słuchaczy i odwieść ich uwagę od szkodliwych widowisk publicznych.

Złotousty Kaznodzieja nie tylko barwnie charakteryzuje aktorów i korzyści płynące z duchowego przedstawienia, ale stara się również dowartościować jego widzów i słuchaczy, podkreślając, że uczestniczą oni w nim i śpiewają razem $\mathrm{z}$ chórami aniołów w obecności samego Chrystusa, co ich powinno zobowiązywać do godnego zachowania:

„Nie przychodzisz tu dla zabawy ani dla tańca, choć niestety jesteś tak niedbały. Czy nie wiesz, że stoisz z aniołami? Że z nimi śpiewasz?" ${ }_{65}$.

„Nie usłyszysz tu tonów szatańskich, ale duchowe. Chcesz zobaczyć tancerzy? - patrz na chóry aniołów. A w jaki sposób możesz ich zobaczyć? jeśli porzucisz tamte, zobaczysz nawet Chrystusa na godach; a jeśli będzie Chrystus, to będzie także i chór aniołów"66.

Jan Chryzostom ma jednak na myśli nie tylko widowiska teatralne, dostarczające przyjemności głównie oczom, ale również stadionowe, w których dominuje walka, wyścigi i biegi, za zwycięstwo w których uzyskuje się zaszczytne wieńce, sławę i nagrody. I on podobnie jak św. Paweł (2Tm 2, 5; 4, 7-8) mówił o duchowym biegu i o duchowej walce z grzechem, nałogami czy szatanem posługując się stadionową terminologią, za zwycięstwo w których osiągało się zwycięski wieniec lub nagrodę wręczaną przez samego Chrystusa jako agonatetę. Przeciwstawiał często stadionową walkę fizyczną duchowej, wskazywał na ich korzyści i szkody, a niekiedy ubolewał, że chrześcijanie w podejmowaniu tej drugiej są często leniwi, gnuśni i niedbali. Jest to tymczasem godna

\footnotetext{
${ }^{64}$ Tenże, In Joannem hom. 1, 1, PG 59, 25-26.

${ }^{65}$ Tenże, In Acta Apostolorum hom. 24, 4, PG 60, 190.

${ }^{66}$ Tenże, In epistulam ad Colossenses hom. 12, 7, PG 62, 389.
} 
podziwu walka nie o jakieś sprawy błahe lub zwyczajny wieniec zwycięski, ale o własne zbawienie i dobra wieczne; jeśli nawet podczas niej niekiedy się upada i przegrywa, to należy się podnosić, bo chodzi tu o rzeczy bardzo ważne:

„Cóż bowiem, pytam, jest przyjemniejszego, cóż bardziej godnego podziwu: czy oglądanie człowieka walczącego z człowiekiem, czy człowieka walczącego z diabłem lub pokonującego i zwyciężającego duchową mocą własne ciało? Te właśnie walki kontemplujmy, te, których naśladowanie jest rzeczą szlachetną i pożyteczną, bo ci, którzy je naśladują, zdobywają zwycięski wieniec" ${ }^{\prime 67}$.

„Czy nie widzisz, jak siedzący na widowni się poca, jak ich odkryte głowy są bombardowane promieniami słońca, czyniąc ich przez to więźniami śmierci [...]. Oni tam pracują na swą zgubę, a ty wobec swego zbawienia jesteś tak leniwy i niedbały? Jesteś przecież atletă, jesteś wojownikiem"68

„Nasza walka nie toczy się o przypadkowe sprawy doczesne. W czasie igrzysk olimpijskich cierpliwie czekacie od północy aż do południa, aby się dowiedzieć, kto otrzyma wieniec zwycięstwa. Wasze odkryte głowy cierpliwie znoszą promienie słoneczne, a żaden $\mathrm{z}$ was nie waży się nawet wstać, dopóki nie rozstrzygną się losy zawodów. My zaś teraz, gdy trzeba nam walczyć nie o taki wieniec, ale o wieniec nieśmiertelności, czujemy się śpiący i zmęczeni”“99.

„Upadłeś, zostałeś powalony na ziemię? Poniosłeś wielką szkodę? Powstań, nabierz sił: pozostań jeszcze na stadionie, widowisko jeszcze trwa. Nie widzisz, ilu mimo iż upadło w bitwie, podjęło na nowo walkę"70.

Nasz kaznodzieja wskazuje ponadto na korzyści i przywileje walki duchowej: zmagający się w niej mogą być wspomagani przez współtowarzyszy modlitwami, zachętami i podtrzymywaniem na duchu, walczących natomiast na arenie czy bieżni atletów, biegaczy lub woźniców, widzowie mogą jedynie podziwiać i oklaskiwać, nie wolno im w żaden sposób pomagać, bo gdyby to chcieli czynić, spotkało by się to $\mathrm{z}$ dezaprobatą i zdecydowanym potępieniem $^{71}$. Zachęca więc swoich słuchaczy do podejmowania osobistych walk duchowych oraz podziwiania ich, gdy inni je dzielnie i skutecznie prowadza, tym bardziej, że są to walki bardzo zaszczytne, bo odbywają się zawsze w obliczu Boga - Króla aniołów:

${ }^{67}$ Tenże, In Joannem hom. 33, 3, PG 59, 188A.

${ }^{68}$ Tenże, In illud: , Vidi Dominum” hom 4, 3, PG 56, 124D.

${ }^{69}$ Tenże, Adversus Judaeos 5, 9, PG 48, 897B, por. thum. J. Iluk w tegoż: Żydowska politeja i Kościót w Imperium Rzymskim u schyłku antyku, t. 1, Gdańsk 2006, 181.

${ }^{70}$ Tenże, In Acta Apostolorum hom. 24, 3, PG 60, 187; por. tenże, In S. Barlaam martyrem, PG 50, 682: „Jesteś, Kochany, żołnierzem Chrystusa; walcz, nie ociaggaj się; jesteś szlachetnym atletą, zachowuj się po męsku, nie dbaj o swe piękno. Tak naśladujmy tych świętych, w ten sposób czcijmy tych dzielnych wojowników, uwieńczonych atletów i przyjaciół Boga".

${ }^{71}$ Por. tenże, In Genesin ser. 2, 1, PG 54, 587; Homilia de resurrectione mortuorum 3, PG 50, 422. 
„Powiedz mi, czy gdyby ci pozwolono uczestniczyć w widowiskach siedząc między książętami i królami, nie uważałbyś tego za coś bardzo zaszczytnego? Tu zaś oglądając z Królem aniołów od tyłu diabła, walczącego i usiłującego

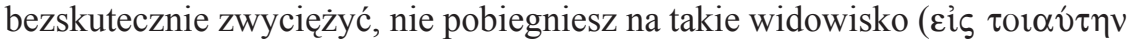
$\theta \varepsilon \omega \rho i ́ \alpha v)$ ? A w jaki sposób, powiesz, takie rzeczy mogą się dziać? - jeżeli trzymasz książkę w rękach; w niej bowiem zobaczysz rowy, tory wyścigowe i ich pułapki oraz artyzm człowieka sprawiedliwego. Jeżeli takie widowiska

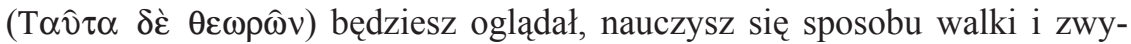
ciężania demonów. Tamte bowiem widowiska są uroczystościami demonów,

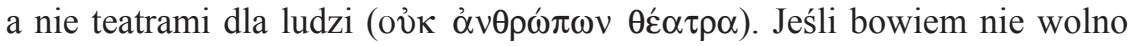
wchodzić do świątyń bożków, to tym mniej wchodzić na uroczystości szatańskie. Nie przestanę tego mówić i powtarzać, dopóki się nie zmienicie [...]. Niech Bóg sprawi, abyśmy uwolnieni od tej brzydoty, stali się godni widowiska duchowego ( $\tau \hat{\eta} \varsigma \pi v \varepsilon v \mu \alpha \tau \imath \kappa \hat{n} \varsigma \theta \varepsilon \omega \rho i ́ \varsigma \varsigma)$ i cieszyli się przyszłą chwałą"72.

Takiego widowiska duchowego, jak widać, według naszego autora może dostarczyć również uważna lektura książki (zapewne Pisma Świętego) oraz kontemplacja jej treści; to ona nauczy nas sposobu walki oraz zwyciężania grzechu i demonów, których uroczystościami są właśnie zakazywane chrześcijanom niemoralne widowiska publiczne.

Zwycięzcy walk stadionowych byli zazwyczaj przyjmowani i honorowani różnymi nagrodami, darami i przywilejami, a zwłaszcza zaszczytnym zwycięskim wieńcem, przez obecnych przeważnie na widowni organizatorów igrzysk - królów, namiestników, cesarzy, czyli agonatetów, to jest „,osoby, które sponsorowały, kontrolowały i nadzorowały z własnej inicjatywy lub z racji kompetencji przypisanych pełnionemu przez nie urzędowi"'73. Jan Chryzostom mówiąc o nagradzaniu zwycięzców walk duchowych przyjmuje również terminologię stadionową, nazywając Chrystusa agonotetą, który ich przyjmuje i wręcza o wiele wartościowsze niezniszczalne wieńce. Przypomina jednak, że prowadząc walkę ze złem i swoimi grzechami nie trzeba się tego wstydzić ani baczyć na względy czy spojrzenia innych, ale pamiętać, że walczy się w obliczu samego Boga, który ją ocenia: w przeciwnym razie walka taka mimo poniesionych trudów pozostanie bezowocna:

„Jezus jak agonoteta przyjmuje uwieńczonego atletę, po wielu jego trudach"74.

„Jak królowie w hipodromach kładą przed stającymi do wyścigów wieńce, nagrody i szaty, tak samo Chrystus kładzie swoje nagrody na środku stadionu i słowami proroka (Iz 48, 6-9) rozdziela je zwycięzcom, jakby wieloma rękami"75.

72 Tenże, In Joannem hom. 32, 3, PG 59, 188B.

${ }^{73}$ Por. D. Słapek, Sport $i$ widowiska w świecie antycznym. Kompendium, Kraków - Warszawa 2010, 150-151.

${ }^{74}$ Joannes Chrysostomus, In Joannem hom. 59, 1, PG 59, 322.

${ }^{75}$ Tenże, In Matthaeum hom. 54, 6, PG 58, 539, por. thum. A. Baron, ŹMT 23, 155. 
„Czy nie widzisz, jak woźnice podczas wyścigów konnych, gdy całe miasto siedzi wysoko [na widowni], przejeżdżając przez cały stadion starają się wyprzedzić wozy konkurentów, gdy zobaczą siedzącego tam cesarza, to spośród tylu patrzących jedne tylko oczy uważają za najgodniejsze uwagi? Ty zaś widząc samego Króla aniołów, który jako agonoteta ( $\alpha \gamma \omega v o \theta \varepsilon \tau o v ̂ v \tau \alpha)$ ocenia twój bieg, nie troszczysz się o Niego, ale baczysz na spojrzenia towarzyszy? Dlatego to po nieliczonych twych walkach odchodzisz nieuwieńczony

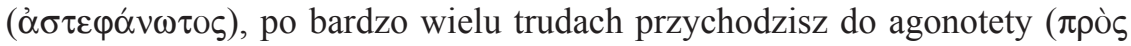

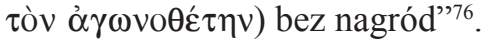

„Nie ma nic lepszego od tej walki; ten wieniec nie ma końca; ten wieniec nie jest upleciony z gałązek dzikiej oliwki, nie ma za sędziego igrzysk człowieka, ani ludzi za widzów; widownia składa się z aniołów. Tam przez wiele dni trudzą się i męczą i w jednej godzinie otrzymują wieniec, a ich radość natychmiast przemija; tu zaś nie tak, lecz zwycięzca jest na zawsze w blasku, w chwale i we czci"'77.

Złotousty Kaznodzieja nie tylko opisuje pewne widowiska duchowe językiem stadionowym, ale również jako takie prezentuje niektóre wydarzenia biblijne dramatyzując je jego terminologią; mają one w ten sposób zastapić stadionowe widowiska publiczne. Tak na przykład zaprezentował w jednej z homilii jako widowisko duchowe scenę składania na ofiarę Izaaka przez Abrahama (Rdz 22, 1-11), ukazując wielką rozterkę i walkę wewnętrzną ojca składającego z polecenia Boga własnego syna na ofiarę:

„Dlatego Bóg zaproponował mu wyższe trybuny i większy stadion ( $\mu \alpha \kappa \rho o ́ \tau \varepsilon \rho \alpha$

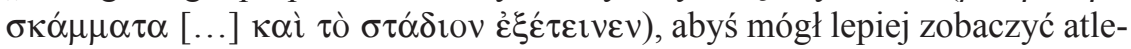

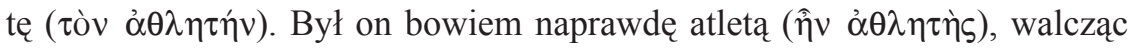
nie tylko z człowiekiem, ale z samą naturą tyraństwa. Jakaż bowiem mowa potrafi wyrazić jego męstwo? Przyprowadził własnego syna, związał, położył na drewnach, chwycił za miecz i już chciał wymierzyć uderzenie"78.

Tak dramatycznie opisane wydarzenie biblijne przykuło zapewne uwagę i wyobraźnię słuchaczy oraz mogło w jakiś sposób zastąpić niejedno tragediowe widowisko publiczne. Nie mniej dramatycznie przedstawił nasz Autor śmierć bogacza i ubogiego Łazarza $\mathrm{z}$ ewangelicznej przypowieści według św. Łukasza $(16,19-31)$, prezentując życie ludzkie jako stadionowy bieg po zwycięski wieniec:

„Zmarł bogacz i został pogrzebany; odszedł i Łazarz, ale nie powiedziałem, że zmarł. Śmierć bowiem bogacza jest rzeczywiście śmiercią i pogrzebaniem, śmierć zaś ubogiego jest wędrówką i przeniesieniem do lepszego stanu, jest

${ }^{76}$ Tenże, In illud: ,, Vidi Dominum” hom. 3, 2, PG 56, 113-114.

77 Tenże, In epistulam II ad Timotheum hom. 9, 2, PG 62, 652, thum. T. Sinko: Św. Jan Złotousty, Homilie na Listy Pasterskie św. Pawła i na List do Filemona, Kraków 1949, 287.

${ }^{78}$ Tenże, De Lazaro con.5, 4, PG 48, 1025. 


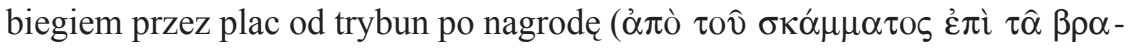

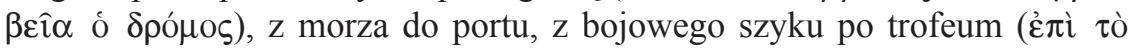

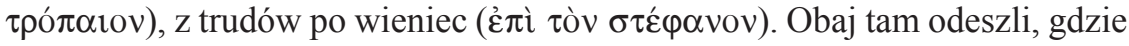

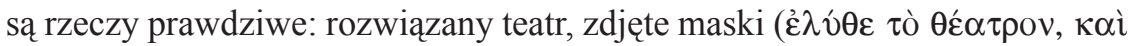

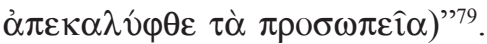

Wiele duchowych widowisk kryło się również, zdaniem naszego złotoustego Biskupa, w uroczyście obchodzonych wspomnieniach męczenników, traktowanych jako herosów chrześcijańskich, którzy zwyciężyli moce demonów, kiedy to urządzano procesjonalne przenoszenie ich relikwii, umieszczanie ich pod ołtarzem, publiczne odczytywanie akt i opisów ich męczeństwa, organizowanie nocnych czuwań i procesji, wygłaszanie ku ich czci specjalnych hymnów, kazań i panegiryków czy publicznych modłów wstawienniczych, a niekiedy także oglądanie rekwizytów i narzędzi ich tortur, czyli odtwarzanie dramaturgii ich męczeństwa ${ }^{80}$. Choć sam pozostawił po sobie wiele różnych homilii i kazań ku czci męczenników, wygłoszonych głównie z okazji przenoszenia ich relikwii, to stosunkowo rzadko przedstawiał ich męczeństwo jako duchowe widowisko. Przykładem takiego duchowego widowiska jest jednak między innymi choćby jego opis męczeństwa najmłodszego z braci Machabejskich w obecności matki, której ból i cierpienie przedstawił barwnie wcześniej ${ }^{81}$ :

„Nie miał on za widza swego męczeństwa żadnego z braci, bo wszyscy byli już zamordowani, ale miał za widza kogoś ważniejszego od braci, miał patrzenie matki [...]. Ta publiczność była wyjątkowo ważna i wielka, bo za widzów miał cały zastęp aniołów oraz braci, już nie z ziemi, ale z nieba [...]. Uwieńczeni zaś jakby sędziowie zawodów olimpijskich siedzieli, nie aby przewodniczyć jurze zawodów, ale aby zachęcać zwycięzcę do walki o wieniec"\$2.

Podobnie jako widowiska męczeństwa wyglądają jego opisy męczeńskiej śmierci św. Ignacego Antiocheńskiego i św. Barlaama:

„Poniósł męczeństwo w środku amfiteatru, gdy całe miasto siedziało wokół i patrzyło, a dzikie zwierzęta zostały nań wypuszczone i poszczute. Poniósł męczeństwo, by na oczach wszystkich widzów wznieść przeciwko diabłu znak zwycięstwa i wielu spośród tych, którzy patrzyli, uczynić naśladowcami swoich zmagań. Na spotkanie śmierci szedł bowiem nie tylko mężnie, ale i z radością, oczekując dzikich zwierząt z rozkoszą, nie jakby miał być wy-

${ }^{79}$ Tamże.5, 5, PG 48, 1034.

${ }^{80}$ Por. Pasquato, Gli spettacoli in S.Giovanni Crisostomo, s. 334-358; S. Poque, Spectacles et festins offerts par Augustin d'Hippone pour les fêtes des martyrs, „Pallas” 15 (1968) 103-125; D.S. Potter, Martyrdom as spectacle, w: Theater and society in classical world, ed. R. Scodel, Ann Arbor 1992, 53-88; tenże, Death as spectacle and subsequent disposal, „Journal of Roman Archeology" 14 (2001) 475-484.

${ }^{81}$ Por. Joannes Chrysostomus, De Maccabaeis hom. 1, PG 50, 617-621, thum. W. Kania, PSP 8, Warszawa 1971, 150-155.

${ }^{82}$ Tamże 2, 1, PG 50, 624. 
rwany z tego życia, ale raczej jakby go wzywano do życia lepszego i znakomitszego... Gdy bowiem zrozumiał, że ma ponieść ten rodzaj śmierci, rzekł: «Obym się uradował tymi zwierzętami» Tak bowiem postępują ci, którzy kochają [...]. Ignacy starał się naśladować Apostołów nie tylko w śmierci, ale i w gorliwości. Słysząc, że oni ubiczowani odchodzili sprzed oblicza rady z wielką radością, chciał także upodobnić się do swych mistrzów nie tylko przez śmierć, lecz także przez radość. Dlatego wołał: «Obym się uradował tymi zwierzętami». I zapewne uznawał za wiele łagodniejsze paszcze dzikich zwierząt niż język tyrana - i nie bez powodu. Ten [bowiem tyran] wzywał do otchłani, a paszcze odsyłały go do Królestwa. Skoro więc tam złożył swe życie, podążył do nieba, a następnie powrócił stamtąd ukoronowany chwałą"83.

Przeciwstawia przy tym treści widowisk publicznych z ich zwykłymi aktorami i zwierzętami widowiskom duchowym z aniołami i świętymi męczennikami, wskazując na większą korzyść z oglądania tych drugich:

„Tam jest pompa diabelska, tu święto chrześcijańskie; tam skaczą z radości demony, tu tańczą aniołowie; tam zguba dusz, tu zbawienie tych wszystkich, którzy się gromadzą [...]. Ale czy tamte widowiska dają jakąś przyjemność? Z pewnością nie taką, jak te: bo jaką przyjemnością jest patrzenie na biegnące konie? Tu zaś nie oglądasz nierozumnych zwierząt, ale tysiące hufców aniołów i Boga, który im przewodzi i prowadzi do nieba"84.

Wskazuje również na konkretne korzyści i różny stan ducha, w jakim wraca się z tych odmiennych widowisk:

„Wracasz potem do domu ubogacony w korzyści duchowe i sam twój wygląd dowodzi wszystkim, że wracasz z widowiska męczenników. Ci zaś, którzy wracają z teatru, łatwo to sobą zdradzają: są niespokojni i podnieceni, zmęczeni i wyczerpani, są prawdziwymi obrazami tego, co tam się działo. Ten natomiast, który wraca z widowiska męczenników, z konieczności łatwo jest rozpoznawany z wyglądu, ze swej postawy, chodu, ze wzruszenia, ze skupienia umysłu, jest pełen zapału, skromny, skruszony, powściagliwy i czujny [...]. Tak wracamy do domu, skromnym i umiarkowanym krokiem, z roztropnością i opanowaniem, z pogodnym i spokojnym obliczem [...]. Tak zawsze wracamy od grobów męczenników, od duchowych namaszczeń, z niebiańskich łąk, z nowych i cudownych widowisk" ${ }^{25}$.

W nazywaniu publicznej egzekucji i męczeństwa chrześcijanina za wiarę widowiskiem lub przedstawieniem Chryzostom nie był oryginalny, bo już przed nim, a zwłaszcza po nim, czynili to już niektórzy z Ojców Kościoła. Być może inspiracją tego i w tym wypadku był św. Paweł, który pisał do Koryntian: „Sta-

${ }^{83}$ Tenże, In S. Ignatium martyrem 8, PG 50, 593-594, tłum. W. Kania, BOK 19, Kraków 2002, 190; por. tenże: In S. Barlaam martyrem 3, PG 50, 679.

${ }^{84}$ Tenże, De SS. martyribus sermo, PG 50, 645.

${ }^{85}$ Tenże, In martyres homilia, PG 50, 665-666. 
liśmy się widowiskiem dla świata" (1Kor 4,2). Wcześniej czynił to często m.in. Euzebiusz z Cezarei $(† 339)^{86}$, a po nim, jak zobaczymy niżej, św. Augustyn.

Złotousty Kaznodzieja oprócz wskazywanych lub tworzonych w swoich homiliach i kazaniach większych lub mniejszych widowiskowych obrazków, które jako duchowe przedstawienia miały odciagać uwagę słuchaczy od wszelkich szkodliwych widowisk publicznych, wybierał w swoich komentarzach biblijnych, jak to zauważa L. Lugaresi ${ }^{87}$, pewne epizody lub wydarzenia z Pisma Świętego i przy pomocy języka teatralnego wysoce je retorycznie opisywał i dramatyzował, tworząc swego rodzaju barwne spektakularne scenki (theatron), którymi nie tylko przykuwał uwage swych wiernych, ale ich również ściągał i zachęcał do oglądania tych ciekawych kościelnych spektakli. Do tego rodzaju udramatyzowanych spektakularnie epizodów biblijnych należały miedzy innymi komentowane miejsca o ofierze z Izaaka, o trzech młodzieńcach w piecu, o męczeństwie siedmiu braci Machabejskich, relacja o Hiobie, o obmyciu stóp Jezusowi przez Magdalenę, o uzdrowieniu paralityka przy sadzawce Betesda, o cierpieniu ewangelicznego Łazarza, co nazywa „,widowiskiem przykrej tragedii” ( $\theta \varepsilon \dot{\varepsilon} \alpha \tau \rho \circ \nu \chi \alpha \lambda \varepsilon \pi$ òv $\tau \rho \alpha \gamma \omega \delta i \alpha \varsigma)$, czy o kobiecie kananejskiej błagającej Chrystusa w obecności wielu widzów ( $\theta \varepsilon ́ \alpha \tau \rho o v)$ o uzdrowienie opętanej córki (Mt 15, 21-22), co nazwał ,godnym politowania

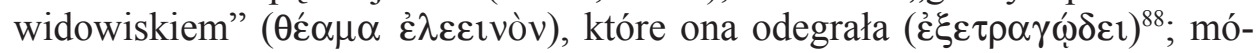
wił też wielokrotnie o ,widowisku Pawła”, ukazując go, jak przemawia bez strachu i zmieszania wobec wrogiego sobie tłumu i podkreślając, że Bóg dał

${ }^{86}$ Por. Eusebius Caesariensis, De martyribus Palaestinae 1, 3, ed. G. Bardy, SCh 55, Paris 1967, 123, tłum. A. Lisiecki, POK 3, Poznań 1924, 464: W 303 r. wielu chrześcijańskich zwierzchników w Cezarei Palestyńskiej „wśród okropnych męczarni walczyło z wielkim męstwem, dając tym, co

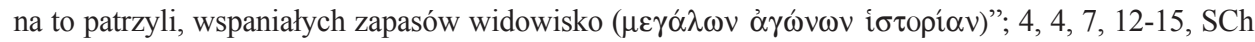
55, 129-136, POK 3, 469-472, 499-500: „męczennik Afianos przed bramami Cezarei jako «bohater-

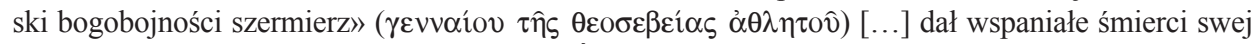

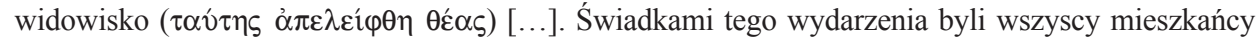

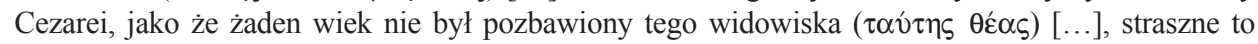
było widowisko dla tych, którzy na nie spoglądali (

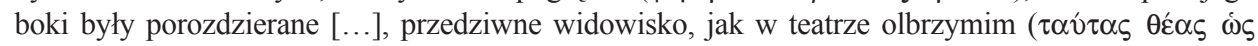

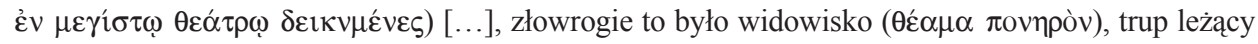
przed samymi bramami miasta”; 9, 11, SCh 55, 151, POK 3, 483: „U samych bram miasta można było oglądać widowisko, przewyższające wszelki opis i wszelkie tragiczne przedstawienie ( $\theta \dot{\varepsilon} \alpha \mu \alpha \pi \alpha \nu \tau o ̀ \varsigma$

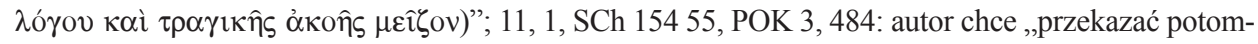
ności wielkie i przesławne widowisko", jakie przez swe męczeństwo dało w 310 r. 12 cezarejskich prezbiterów z Pamfilosem na czele.

${ }^{87}$ Por. Lugaresi, Il teatro di Dio, s. 799-805 (Episodi «spettacolari» della Scrittura).

${ }^{88}$ Por. Joannes Chrysostomus, Quod nemo laeditur nisi a seipso 10, PG 52, 471; In epistulam II ad Corinthios hom. 3, 5, PG 61, 412-413; Ad populum Antiochenum hom. 4, 4, PG 49, 64; De Meletio Antiocheno 3, PG 50, 518; In Matthaeum hom. 4, 10, PG 57, 52; In epistulam I ad Corinthios hom. 18, 3, PG 61, 149; Adversus Judaeos hom. 8, 6, PG 48, 936; Ad populum Antiochenum hom. 1, 8, PG 49, 26-27; De Maccabaeis hom. 2, 1, PG 50, 624; Adversus Judaeos hom. 5, 2, PG 48, 885; In Matthaeum hom. 80, 1, PG 58, 725 oraz hom. 52, 1, PG 58, 519. 
mu ,wspaniałą widownię” ( $\lambda \alpha \mu \pi \rho o ̀ v ~ \theta \varepsilon ́ \alpha \tau \rho o v)$, przed którą mógł przedstawić swoją obronę ${ }^{89}$. Szczególnie mocno dramatyzował w ten sposób, gdy komentował główne epizody z życia Chrystusa, zwłaszcza te o charakterze publicznym, kiedy to thum zebranych ludzi lub publiczność często nazywał wprost „teatrem” $(\theta \varepsilon \dot{\varepsilon} \alpha \rho \circ)^{90}$, widownią lub widowiskiem, jak na przykład, gdy opisywał chrzest Jezusa w Jordanie, będący publiczną manifestacją Jego bóstwa, nazywając to ,wielkim widowiskiem"91, albo też biblijną scenę ukrzyżowania Chrystusa, którą znów nazywa ,zbrodniczą tragedią” i skandalicznym widowiskiem „W powszechnym teatrze świata”, podkreślając jej spektakularność:

„[Bóg] dokonał zmartwychwstania w skrytości i w miejscu odosobnionym, powierzając całemu biegowi historii jego udowodnienie, ale krzyż postawił

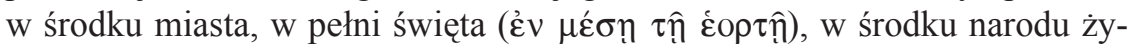
dowskiego, w obecności dwóch trybunałów - rzymskiego i żydowskiego,

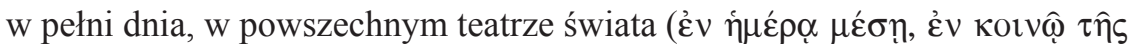

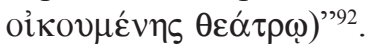

„A iluż to uczniów zgorszyło się z powodu krzyża. Jeden zdradził Pana, inni pouciekali, jeden się Go zaparł i gdy wszyscy szli z daleka, Pana osamotnionego prowadzono w więzach [...]. Było przy tym wielu ludzi, obchodzono bowiem wielkie święto i miasto, w którym wystawiono - a było to w południe - tę zbrodniczą tragedię, było metropolią. Iluż wtedy obecnych zgorszyło się na widok Pana związanego, ubiczowanego, zbroczonego krwią, przesłuchiwanego przed trybunałem prefekta, gdzie nie było żadnego ucznia. Potem

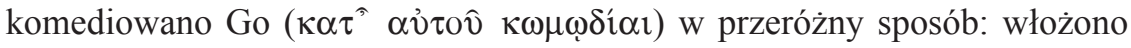
Mu koronę cierniową i płaszcz, podano do ręki trzcinę i oddawano pokłon nie

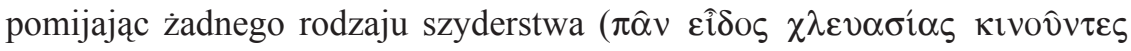

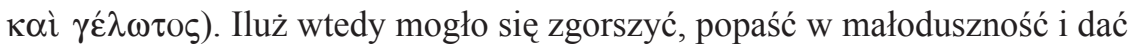
się uwieść, gdy Go bito po twarzy i wołano: «Prorokuj nam, Chryste, kto cię uderzył». A potem, gdy prowadzono Go tu i tam, cały dzień szydzono

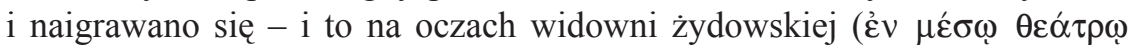

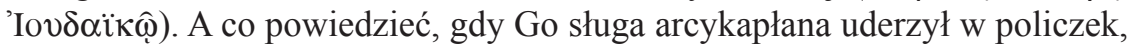
żołnierze rozdzielili Jego szaty między siebie, obnażonego przybito do krzyża i na krzyżu powieszono, a na Jego plecach widać było krwawe ślady biczowania. Nawet bowiem wtedy nie miękły te dzikie zwierzęta, lecz wście-

${ }^{89}$ Por. np. tenże, In Acta Apostolorum hom. 47, 1, PG 60, 327; In epistulam ad Colossenses hom. 10, 4, PG 62, 371; In Acta Apostolorum hom. 52, 2, PG 60, 362.

${ }^{90}$ Por. np. dwa razy w In paralyticum demissum per tectum 5, PG 51, 56-57; In Genesin ser. 4, 3, SCh 433, 240; In principium Actorum hom. 4, 8, PG 51, 109.

${ }^{91}$ Por. tenże, In Matthaeum hom. 10, 2, PG 57, 186, ŹMT 18, 124-125: „Dlatego Jezus sam przyszedł, aby przyjąć chrzest. Sława bowiem Chrzciciela oraz istota samej rzeczy przyciagały i sprowadzały nad Jordan całe miasto, tak że widowisko było wielkie [...]. Potrzebne więc było świetne wystąpienie i mocny początek. Dlatego właśnie wtedy ogłasza po raz pierwszy donośnym głosem to, o czym Żydzi jeszcze nie słyszeli ani od proroków, ani od nikogo innego".

${ }^{92}$ Tenże, Ad eos qui scandalizati sunt 17, 9, éd. A.-M. Malingrey, SCh 79, Paris 1961, 228. 


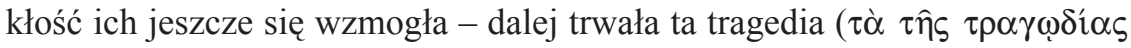

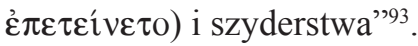

Tak dramatycznie przedstawiona scena męki i ukrzyżowania Chrystusa wywołała zapewne nie mniejszą ciszę, napięcie uwagi i skupienie u słuchaczy niż niejedna dramatyczna akcja w tragedii klasycznej. A było to faktycznie ze wszystkimi znamionami tragiczne widowisko publiczne ${ }^{94}$, co podkreślało już kilku wcześniejszych i późniejszych Ojców Kościoła ${ }^{95}$. Tego rodzaju dramatyzowanie komentowanych epizodów biblijnych przez Chryzostoma miało jednak za zadanie nie tylko zainteresować i pouczyć jego słuchaczy, ale również oderwać ich od widowisk publicznych i sprowadzić ich do kościoła na chrześcijańskie widowiska duchowe, którymi w tym wypadku było objaśnianie Pisma Świętego.

Jan Chryzostom jako odpowiedzialny duszpasterz wyjątkowo często potępiał wszelkie gorszące widowiska publiczne, zachęcając swoich wiernych, by przez ich oglądanie nie mieszali zasłyszanych i czerpanych w kościele Bożych tajemnic z szatańskimi, by szanowali często podeszły swój wiek i chrześcijańską godność i nie uczęszczali na nie, wykazując, że nie przynoszą im one żadnego pożytku, ale tylko moralną szkodę. Wiedział jednak, że nie wszystkich jego argumentacja przekonywała, że jego zachęty i mowy dla wielu były nudne, śmieszne i bezskuteczne, że ciagłe mówienie im o korzystaniu z duchowych zastępczych widowisk i o staraniu się jedynie o niebieskie nagrody i nieśmiertelne wieńce w przyszłym życiu nie zawsze ich przekonywały, bo oni, jak ogół ludzi starożytnych, zwłaszcza z większych metropolii, dostrzegali również znaczenie i wartość doczesnych stadionowych nagród i zwycięskich wieńców. Wzywał ich więc do refleksji, wskazując na konkretne szkody wynikające z uczestnictwa w widowiskach publicznych i korzyści płynące $\mathrm{z}$ widowisk duchowych, przywołując też niekiedy tradycyjnie czekającą ich wizję sądu ostatecznego:

„Często was zachęcałem, aby nikt z tych, którzy tu przychodzą i korzystają z Bożej nauki oraz są uczestnikami budzącej lęk mistycznej Ofiary, nie chodził na owe widowiska ( $\tau \grave{\alpha} \theta \varepsilon \dot{\varepsilon} \alpha \tau \rho)$ i nie mieszał Bożych tajemnic z szatańskimi. Niektórzy jednak do tego stopnia szaleją w tym względzie, że chociaż cieszą się powagą i dużym szacunkiem oraz osiagnęli już pełną siwiznę, na

${ }^{93}$ Tenże, Epistula ad Olympiadem 7, 4, éd. A.-M. Malingrey, SCh 13bis, Paris 1968, 148, thum. W. Kania, BOK 19, Kraków 2002, 216; zob. In Matthaeum hom. 87, 1-2, PG 58, 770, ŹMT 23, 501 502: „Dlatego też ukrzyżowali go publicznie, aby mogli z Niego szydzić wobec wszystkich; dlatego - za pośrednictwem żołnierzy, aby jeszcze bardziej mogli dać upust swej wściekłości, ponieważ działo się to w sądzie publicznym [...]. Dlatego mówią o tym publicznie, krzyżują złoczyńców razem z Nim, chcąc pokazać, że jest oszustem [...] ukrzyżowany na oczach całego miasta, a raczej narodu żydowskiego, cudzoziemców, rodaków, do których przemawiał tak łaskawie".

${ }^{94}$ Por. Lugaresi, Il teatro di Dio, s. 298-309 (Lo spettacolo della crocifissione); M. Hengel, Crocifissione ed espiazione, Brescia 1988, spec. s. 40-41, 126-127.

${ }_{95}$ Por. np. Melito Sardensis, De Pascha 94 i 97; Ambrosius, Expositio Evangelii secundum Lucam X 104-109; Gregorius Nazianzenus, Oratio 30, 5, 6. 
nie biegają, nie słuchając naszych mów i nie szanując swej godności. Kiedy im przypominamy i zachęcamy, by szanowali swoją siwiznę i powagę, nasza mowa jest dla nich śmieszna i jałowa. Obiecywanie zwycięskich nagród i wieńców w przyszłym wieku - mówią - choćby były bardzo wielkie, nie przynoszą nam teraz korzyści. Co ty mówisz, człowieku? Jest to mowa niesmaczna i bardzo zwodnicza. A jakie korzyści z nich odnosisz? Czy z niezliczonych na nich kłótni i lekkomyślnie składanych przysiąg? Czy z obelg, wyzwisk i szyderstw, którymi widzowie wzajemnie się na nich obsypują? Ależ z nich nie ma żadnego pożytku. Czy w ogóle jest jakiś pożytek z rozwiązłych przezwisk i pustych krzyków? [...]. Tymczasem tu [w kościele] wszyscy prorocy i nauczyciele ukazują ci samego Pana aniołów, siedzącego na wzniosłym wysokim tronie, rozdzielającego tym, którzy zasłużyli, nagrody i wieńce, a tym, którzy są niegodni -piekło i ogień; sam Pan to także potwierdza. Czy więc będziesz gardził tymi zachętami, w których mieści się również niepokój sumienia, lęk zdania sprawy za dokonane czyny i świadomość poniesienia nieuniknionej kary? Aby znaleźć absurdalne uzasadnienie dla widowisk, na które zwykłeś się gapić, mówisz, że czerpiesz z nich korzyść, a z których faktycznie doznajesz tylko dogłębnej ruiny" ${ }^{\prime 96}$.

Jan Złotousty będąc zdecydowanym przeciwnikiem wszelkich widowisk publicznych, które w większości uważał za szkodliwe, przyczynił się chyba najwięcej spośród autorów wczesnochrześcijańskich do ich wyeliminowania z życia chrześcijan na Wschodzie. On je jednak nie tylko ustnie i pisemnie zwalczał i potępiał, ale również bardzo wieloma różnymi sposobami i propozycjami, jak przypomnieliśmy wyżej, starał się je zastąpić. Posługiwał się przy tym nierzadko, by być lepiej zrozumianym, także terminologią teatralną i widowiskową, ale w sensie szerszym i pozytywnym w odniesieniu do rzeczywistości duchowych. Tak np. „teatrem” ( $\theta \dot{\varepsilon} \alpha \tau \rho o v)$ oprócz publiczności i widowni nazywał także niekiedy raj ${ }^{97}$, zaś często używane wyrażenie ,teatr duchowy" ( $\pi v \varepsilon v \mu \alpha \tau \imath \kappa o ̀ v ~ \theta \varepsilon ́ \alpha \tau \rho o v)$ rozumiał już to w sensie przedmiotowym na oznaczenie widowiska duchowego, o którym mówiliśmy wyżej, już to w sensie podmiotowym na oznaczenie zgromadzenia ludzi, którzy je kontemplują $^{98}$, kiedy natomiast mówił o teatrze duchowym, to był zawsze w kręu, który wykluczał konkretne przedstawienie sceniczne jakiejś rzeczywistości

\footnotetext{
${ }^{96}$ Joannes Chrysostomus, In illud: ,,Vidi Dominum” hom. 1, 4, PG 56, 102-103; por. tenże, In Joannem hom. 32, 3, PG 59, 188.

${ }^{97}$ Por. tenże, Ad Theodorum lapsum I 11, éd. J. Dumortier, SCh 117, Paris 1966, 142; Adversus Judaeos hom. 8, 7, PG 48, 938.

${ }^{98}$ Por. np. tenże, In illud: „,Vidi Dominum” hom. 5, 1, PG 56, 129-131; De S. Pelagia virgine et martyre 3, PG 50, 582; In illud Isaiae dictum: „Ego Dominus Deus feci lumen” 1, PG 56, 143; Contra ludos et theatra 1, PG 56, 264; In martyres hom., PG 50, 663; In S. Julianum martyrem 4, PG 50, 673; De fato et providentia 1, PG 50, 754; De gloria in tribulationibus 3-4, PG 51, 162; In dictum Pauli: „, Oportet haereses esse” 1, PG 51, 251; In Joannem hom. 3, 1, PG 59, 37; zob. Lugaresi, Il teatro di Dio, s. 805.
} 
mitologicznej lub zmyślonej, a wyrażał myśl pełnej korespondencji między widzialnością zewnętrzną a prawdą substancjalną.

\section{AUGUSTYN}

Kolejnym wczesnochrześcijańskim autorem, który w swej młodości pasjonował się wszelkimi widowiskami publicznymi, a później je zwalczał i próbował zastąpić innymi, typowo chrześcijańskimi , był również wielki biskup afrykańskiej Hippony - św. Augustyn († 430). Znał on dobrze bujne życie widowisk zarówno wielkich metropolii Cesarstwa - Kartaginy, Rzymu i Mediolanu, jak i mniejszych regionalnych ośrodków - m.in. Tagasty ${ }^{99}$ i Hippony, oraz widział, ile szkód one wyrządzają moralności chrześcijańskiej, ale znał również z własnego doświadczenia zamiłowanie i pasję ludzi starożytnych do wszelkich widowisk i wiedział, że samo ich potępianie i zakazywanie niewiele pomoże, lecz żądzę ich oglądania i przeżywania trzeba czymś zastapić, wskazując jakieś zastępcze odpowiednie dla chrześcijan imprezy ${ }^{100}$, które by zaspokajały ich wrodzone pragnienie i przyjemność oglądania. Nie eliminuje więc z życia chrześcijan wszelkich widowisk, bo uważa, że jest to niemożliwe, owszem, jako jedyny Ojciec Kościoła zapewnia swoich wiernych, że Bóg nie pozostawił ich bez widowisk; chrześcijanie też mają swoje widowiska, i to nawet lepsze od tych, jakie mają poganie. Jako jedyny Ojciec Kościoła uznaje potrzebę istnienia i oglądania widowisk: człowiek bowiem ze względu na swą słabą naturę ma potrzebę oglądania obrazów widzialnych i materialnych, bo mu to ułatwia rozumienie i zapamiętywanie rzeczywistości duchowych i abstrakcyjnych prawd wiary podczas osobistej medytacji czy słuchania katechetycznych mów i homilii ${ }^{101}$. W miejsce rzeczywistej i właściwej wizji widowiska, na którego scenie aktorzy występują w przestrzeni materialnej, Augustyn proponuje formę wizji wewnętrznej obrazów wypracowanych i udramatyzowanych przez wyobraźnię wiernego, słuchającego przepowiadania chrześcijańskiego; są to obrazy wywołane również przez osobistą medytację tekstów Pisma Świętego, ponieważ Bóg przez swą łaskę różnymi sposobami dla ich zrozumienia pomaga je tworzyć, uwzględniając przy tym nieporadność i słabość ludzkiej natury. Kaznodzieja czy mówca chrześcijański, nauczający prawd wiary lub komentujący wydarzenia biblijne, ma także słuchaczowi ułatwić z pomocą Ducha Świętego to wypracowanie sobie ich wizji w swoim teatrze myślowym ${ }^{102}$ :

${ }^{99}$ Por. J. Garcia, Thagaste, ville chrétienne à l'epoque de S. Augustin, CPE 2007, nr 106, 27-44.

${ }^{100}$ Por. Weismann, Kirche und Schauspiele, s. 173-175 (Hinweis auf die besseren ,spectacula christiana”); Lugaresi, Il teatro di Dio, s. 676-693 (Gli „spettacoli” dei cristiani).

${ }^{101}$ Por. Augustinus, De Trinitate XI 1, 1, ed. W.J. Mountain - F. Glorie, CCL 50, Turnhout 1968, 333-334, tłum. M. Stokowska, POK 25, Poznań 1963, 310-311.

${ }^{102}$ Por. tenże, De vera religione 50, 98 i 51, 100, ed. K.-D. Daur, CCL 32, Turnhout 1962, 250 i 252: „Jeśli nie jesteśmy jeszcze zdolni przylgnąć całkowicie do życia wiecznego, to umartwmy 
„Sercu chrześcijanina Bóg przedstawia wielkie widowiska (magna spectacula), ponad które niczego milszego znaleźć nie podobna, pod warunkiem, że posiadamy podniebienie wiary, które może zasmakować miodu Bożego. Spodziewamy się, że we wszystkich was, którzy całym sercem uwierzyliście naszemu Zbawicielowi, przebywa Jego Duch, który użycza wam rozkoszy, kiedy odczytywane są proroctwa, które przed tyloma laty wyszły z ust świętych, a po tylu latach wypełniły się w wierze pogan... Niechaj sam Pan Bóg nasz wzbudzi w was oczekiwanie i radość tak wielkiej rzeczy. Niechaj sam kieruje naszym kazaniem odpowiednio do waszych serc, żeby to wszystko, co raduje serce nasze na widok takich widowisk (talibus spectaculis), przekazał językowi, a przez niego waszym uszom, potem do serca, a wreszcie do waszych czynów"103.

Są to zatem widowiska wewnętrzne, przedstawienia teatru myślowego, zapowiedzi widowiska niebiańskiego, które są dostrzegane, odczytywane i interpretowane przez samych chrześcijan z pomocą wiary jako ich aktorów (a nie widzów) w metaforycznym teatrze świata, którego Bóg jest jedynym panem i sędzią ${ }^{104}$. Biskup Hippony nazywa je często, jak zaznaczono niżej, ,,widowiskami chrześcijańskimi" (spectacula christiana) ${ }^{105}$, odnosząc to wyrażenie do wizji duchowych, wywołanych przez przepowiadanie słowa Bożego podczas liturgii, a nie do samego rytu lub samej liturgii chrześcijańskiej jako takiej, jak

przynajmniej nasze fantazje i usuńmy z naszego teatru myślowego widowiska tak czcze i zwodnicze (et tam nugatorios et deceptorios ludos de spectaculo mentis eiciamus). Skorzystajmy z owych szczebli, które Opatrzność Boża raczyła nam sporządzić. Kiedy my tymczasem zbyt zachwyceni bawiącymi nas fikcjami igraszkowymi (figmentis ludicris), osłabliśmy w naszych myślach i całe życie zmieniliśmy niejako w czcze sny, to niewyczerpane miłosierdzie Boże nie wzdrygało się bawić z nami jak z dziećmi przypowieściami i podobieństwami... przemawiając do nas przez pośrednictwo dźwięków, pisma, ognia, dymu, chmury czy słupa, jakby przez jakiś rodzaj słów widzialnych (quasi quaedam verba visibilia), i w ten sposób uleczyć nasze wewnętrzne oczy [...]. Porzućmy więc i pozostawmy teatralne i poetyckie fikcje, a ducha wycieńczonego i palonego głodem i pragnieniem czczej ciekawości (vanae curiositatis fame ac siti fessum et aestuantem) nakarmmy i napójmy rozważaniem i roztrząsaniem Pisma Świętego, jakby malowanymi potrawami”, por. thum. W. Eborowicz, Św. Augustyn, Dialogi filozoficzne, Kraków 2001, 807-809.

${ }^{103}$ Tenże, Enarrationes in Ps. 96, 1 i 3, ed. D.E. Dekkers - I. Fraipont, CCL 39, Turnhout 1956, 1354 i 1356, PL 37, 1237 i 1239: „Magna spectacula Deus praebet cordi christiano et quibus vere nihil possit iucundius inveniri; si tamen adsit palatum fidei, cui sapiat mel Dei. Credimus omnibus vobis, qui in Salvatorem nostrum toto corde credidistis, inesse Spiritum eius, qui vos delectet, cum leguntur prophetiae [...]. Excitet vobis ipse Dominus Deus noster dignam tantae rei exspectationem et iucunditatem; ipse sermonem nostrum moderetur aptum cordibus vestris, ut quiquid hic exsultat cor rostrum in talibus spectaculis, perducat ad linguam, et inde in aures vestras, deinde in cor vestrum, inde in facta vestra", thum. J. Sulowski, PSP 40, Warszawa 1986, 279-282.

${ }^{104}$ Por. Lugaresi, Il teatro di Dio, s. 677.

${ }^{105}$ Por. tenże, Vanitas ludus omnis. Il problema degli spettacoli nel cristianesimo antico (II-V secolo), Diss., Bologna - Paris 2006, 742-750 (autor wylicza je i analizuje). 
to chciał rozumieć m.in. A. Mandouze ${ }^{106}$, przytaczając jako przykład Enarratio in PS. 80, $23^{107}$.

„Nie sądźcie, bracia, że Pan Bóg nasz pozostawił nas bez widowisk"108.

„Zostawimy ich bez widowisk? [...]. Dajmy im widowiska za widowiska”109.

Są to jednak widowiska inne: w przeciwieństwie do pogańskich widowisk publicznych, które przynoszą szkodę moralności chrześcijańskiej, widowiska chrześcijańskie (spectacula christianorum, spectacula christiana) lub boskie (spectacula divina) są zawsze ,pożyteczne, zbawienne, budujące i nie burzące" (utilia, salubria aedificantia):

„Umysły wasze w imię Chrystusa nie mało zatrzymały boskie widowiska i zachwyciły was, nie tylko do pozyskania pewnych rzeczy, ale i do ich uniknięcia. Są to widowiska pożyteczne, zbawienne, budujące i nie burzące. Co więcej, i burzące i budujące: burzące nowych bogów, budujące wiarę w prawdziwego i wiecznego Boga [...]. Jak słyszeliśmy, tamci jutro będą mieli morze w teatrze, a my miejmy port w Chrystusie" $" 10$.

Są to dalej widowiska lepsze i owocniejsze (meliora, fructuosiora) oraz przynoszące wszystkim ich widzom i uczestnikom pełną radość i nagrodę, a nie tylko jednemu zwycięzcy, bo są to prawdziwe cuda Boże (miracula Dei) i zamysły Boże (cogitationes Dei), a ich powodem nie jest żądza (cupiditas) sławy czy bogactwa, ale wzajemna miłość (caritas).

„Takie to są cuda Boże, takie Boże zamysły, i nic do nich nie jest w tej mierze podobne. Ów widz zostaje odciagnnięty od ciekawości i wraz z nami zacznie szukać tego, co lepsze, co bardziej owocne, a znalazłszy je, będzie się radował. Radował się zaś będzie w taki sposób, iż nie będzie się obawiał, że zostanie zwyciężony ten, kogo kocha. Kocha bowiem woźnicę, a gdy ten zostanie pokonany, spotkają go szyderstwa. Kiedy zaś woźnica zwycięży, on tylko zostaje udekorowany. A czyż spotka to biedaka, który na jego cześć

${ }^{106}$ Por. A. Mandouze, Prosopographie chrétienne du Bas-Empire, vol. 1: Prosopographie de l'Afrique chrétienne (303-533), Paris 1982, 639, nota 1; Lugaresi, Il teatro di Dio, s. 678, n. 495.

107 Tekst ten zob. przypis nr 110.

${ }^{108}$ Augustinus, In Joannis evangelium tract. 7, 6, ed. R. Willems, CCL 36, Turnhout 1954, 70: „Ne putetis, fratres, quod sine spectaculis nos dimisit Dominus Deus noster”.

${ }^{109}$ Augustinus, Enarrationes in Ps. 39, 9, PL 36, 439 lub ed. D.E. Dekkers - I. Fraipont, CCL 38, Turnhout 1956, 432: „Dimissuri eum sumus sine spectaculo? [...]. Demus pro spectaculis spectacula"; por. thum. J. Sulowski, PSP 38, Warszawa 1986, 93.

${ }_{110}$ Tamże 80, 23, PL 37, 1046 lub ed. D.E. Dekkers - I. Fraipont, CCL 39, Turnhout 1956, 1135: „Non parum vestras mentes in nomine Christi divina spectacula tenuerunt et suspenderunt vos, non solum ad appetenda quaedam, sed ad quaedam etiam fugienda. Ista sunt spectacula utilia, salubria, aedificantia, non destruentia: imo et destruentia et aedificantia; destruentia recentes deos, aedificantia fidem in verum et aeternum Deum [...]. Cras illi habent, ut audivimus, mare in theatro, nos habeamus portum in Christo", tłum. J. Sulowski, PSP 40, Warszawa 1986, 44; por. Tertullianus, De spectaculis 29, 3, SCh 332, 312; Novatianus, De spectaculis 10, 3, CCL 4, 179. 
krzyczy? Sam zwycięzca zostaje uwieńczony, za pokonanego biedak jest tylko wyśmiany. Dlaczego więc za niego znosisz wyrzuty, skoro razem z nim nie dzielisz szaty zwycięstwa? Inaczej rzecz się ma na naszych widowiskach: «wprawdzie wszyscy biegną» na owym stadionie, podczas tamtego widowiska - powiada Paweł Apostoł - «ale jeden tylko otrzymuje nagrodę» (1Kor $11,29)$, reszta zwyciężonych odchodzi. Wytrzymali w biegu, lecz jeden tylko otrzymał nagrodę, mimo że inni tak samo się trudzili. Tu natomiast nie jest tak: ilu tylko biegnie, a niechaj biegną wytrwale, wszyscy zostaną nagrodzeni; kto zaś przybędzie pierwszy, poczeka aż razem z ostatnim zostanie uwieńczony. Taki bowiem agon przygotowuje miłość, a nie pożądliwość; wszyscy uczestniczący w biegu wzajemnie się miłują, a biegiem jest sama miłość"111.

I nie tylko publiczne widowiska dostarczają przyjemności, bo dostarcza je także każde widowisko chrześcijańskie lub boskie, jeśli tylko jest odpowiednio i ze skupieniem przeżyte; dostarczają one przyjemności przeważnie zmysłom ciała, ale pierwsze są na ogół niedozwolone (illicita), drugie dozwolone (licita); te drugie, zwłaszcza piękne cuda natury, nie tylko napełniają widzów autentyczną radością, ale również kierują ich myśli i uczucia do ich prawdziwego Twórcy:

„Czy was nie cieszą takie widowiska, gdy nie zasługujemy się w oczach ich wystawcy, ale w oczach samego Zbawiciela?" 112

„Czy sądzicie, bracia, że są tacy, którzy Boga się boją, Boga czczą, Boga miłuja, a nie mają żadnych uczuć? Czy rzeczywiście myślisz i ośmielisz się sądzić, że uczucia kierują się jedynie do szachownicy, do teatru, polowania, łapania ptaków, łowienia ryb, a nie odnoszą się do dzieł Bożych? Czyż nie wzbudza pewnych wewnętrznych uczuć rozważanie o Bogu, kiedy obserwuje się świat, a przed oczy stawia się widowisko natury rzeczy i doszukuje się wtedy Mistrza oraz przekonuje się, że pod żadnym względem niczego nie można mu zarzucić, gdyż podoba się bardziej niż wszystko inne?”"13

${ }^{111}$ Augustinus, Enarrationes in Ps. 39, 11, PL 36, 441 lub CCL 38, 433-434: „Haec miracula ei sunt, hae cogitationes Dei sunt, quibus nemo est similis: ut spectator ille abducatur a curiositate, et quaerat ista nobiscum meliora, fructuosiora, de quibus inventis gaudebit; et sic gaudebit, ut non timeat ne vincatur quem amat: amat enim aurigam, quo victo insultationes ferat [...]. Hac aliud in spectaculis nostris [...]. Agonem quippe istum non cupiditas, sed caritas facit: omnes currentes amant se, et ipse amor cursus est”, PSP 38, 94-95 (przekład poprawiony przez autora).

112 Tenże, Sermo 9, 13, PL 38, 85: „Non vos delectant talia spectacula, ubi non promeremur oculos editoris, sed oculos Redemptoris?"

113 Tenże, Enarrationes in Ps. 76, 14, PL 36, 978, lub CCL 39, 1061: „Quis vivit sine affectionibus? Et putatis, fratres, quia qui Deum timent, Deum colunt, Deum diligunt, nullas habent affectiones? Vere, hoc putabis, et putare audebis, quod affectiones habeat tabula, theatrum, venatio, aucupium, piscatus, et non habeant opera Dei? Et non habeat meditatio Dei interiores affectiones quasdam suas, cum inspicitur mundus, et ponitur ante oculos spectaculum naturae rerum, et in his quaeritur artifex?", tłum. J. Sulowski, PSP 39, Warszawa 1986, 366; zob. też tamże 142, 10, ed. D.E. Dekkers - I. Fraipont, CCL 40, Turnhout 1956, 2067, tłum. J. Sulowski, PSP 42/1, Warszawa 
„Naszą słabość cieszą pewne rzeczy naturalne, jak pokarm czy napój cieszą głodnych i spragnionych; podobnie cieszy nas światło, które promieniuje z nieba po wzejściu słońca, albo z gwiazd i księżyca, cieszy też nasze oczy światło zapalane na ziemi, cieszy nas wdzięczny głos i słodka piosenka, cieszy także miły zapach. Z tych wszystkich, które sprawiają przyjemność zmysłom ciała, niektóre są dozwolone. Cieszą bowiem oczy wielkie widowiska natury, ale cieszą także oczy widowiska teatrów: tamte są dozwolone, te niedozwolone. Cieszy słuch słodko śpiewany święty psalm, ale cieszą także słuch kantyki aktorów: tamten jest dozwolony, te niedozwolone. Cieszą powonienie zapachy stworzonych przez Boga kwiatów, ale cieszą także powonienie kadzidła przy ołtarzach demonów: tamte dozwolone, te niedozwolone. Cieszy smak niezabronionego pokarmu, ale cieszy także smak uczty świętokradczych ofiar: tamten dozwolony, ten niedozwolony [...]. Widzicie zatem, najdrożsi, dla zmysłów ciała są przyjemności dozwolone i niedozwolone"114.

Nietrudno zauważyć, że również Augustyn w dwóch ostatnich cytatach zaleca tradycyjnie znane już stoikom podziwianie cudów i piękna natury, które on nazywa ,wielkimi widowiskami natury” (spectacula magna naturae), które jednak nie tylko dostarczają przyjemności z oglądania, ale także dowodzą istnienia, wielkości i wszechmocy ich Twórcy; trzeba tylko umieć dostrzegać w nich i kochać Stwórcę tej natury, który jest od niej jeszcze piękniejszy i większy:

„Ten, który stworzył wszystko, lepszy jest od wszystkiego. Ten, kto stworzył rzeczy piękne, piękniejszy jest niż wszystko inne. Ten, kto stworzył rzeczy mocne, jest mocniejszy. Kto stworzył rzeczy większe, jest jeszcze większy. Cokolwiek umiłujesz, będzie dla ciebie zawsze pierwszym. Ucz się kochać Stwórcę w stworzeniu, a Sprawcę w dziele, abyś nie zatrzymywał się na tym, co stworzone, a przez to nie utracił Tego, który również ciebie stworzył"115.

Wszelkie widowiska publiczne, w tym cyrkowe, amfiteatralne i teatralne, sa, zdaniem naszego Biskupa Hippony, jedynie szaleństwem zwodniczym, a oglądający je, także chrześcijanie - godnymi politowania ludźmi błądzącymi, których nie tyle należy potępiać, co za nich się modlić, by się nawrócili, bo wielu z nich bez oglądania widowisk nie potrafi żyć, ale i tych nie można zostawiać: w zamian za publiczne widowiska, których się wyrzekli, trzeba im

1986, 258: „Ty naturalnie wszystko uczyniłeś dobre, i nic nie zaistniało, czego byś Ty nie ustanowił. Twoje stworzenie stało się dla mnie widowiskiem".

${ }_{114}$ Tenże, Sermo 159, 2, PL 38, 868: „Et haec omnia, quae nos delectant in sensibus corporis, aliqua licita sunt. Delectant enim, ut dixi, oculos spectacula ista magna naturae, sed delectant oculos etiam spectacula theatrorum: haec licita, illa illicita. Psalmus sacer suaviter cantatus delectat auditum, sed delectant auditum etiam cantica histrionum: hoc licite, illud illicite [...]. Videtis ergo, carissimi, in istis corporis sensibus licitas et illicitas delectationes".

115 Tenże, Enarrationes in Ps. 39, 8, PL 36, 439 lub CCL 38, 431: „Disce amare in creatura Creatorem et in factura Factorem: ne teneat te quod ab illo factum est, et amittas eum a quo et ipse factus es", PSP 38, 92-93. 
zaproponować inne - przedstawienia chrześcijańskie, wołając: „Za widowiska dajmy im widowiska”, bo bez nich w ogóle nie można ich zostawiać. A jakie? Oprócz podziwiania dzieł natury i świata stworzonego Autor nasz w formie retorycznego dialogu ze słuchaczami proponuje im za psalmem (Ps 39, 10) oglądanie ,przedziwnych rzeczy Bożych” (mirabilia Dei), o których wiele mówi Pismo Święte i historia zbawienia. A konkretnie: zamiast np. z napięciem śledzić walkę woźnicy ujarzmiającego w cyrku konie, można podziwiać człowieka ujarzmiającego swoje wady i namiętności, zamiast linoskoczka w amfiteatrze - św. Piotra chodzącego po wodzie. Na te przedziwne dzieła Boże, by je należycie odczytać, by nie powszedniały, i podziwianiem ich zastapić oglądanie widowisk publicznych, należy jednak zawsze patrzeć oczyma wiary, a w dodatku samemu stać się widowiskiem dla innych w swoich wewnętrznych zmaganiach się i walkach ze złem o zwycięstwo, w czym zawsze można liczyć na niezawodną pomoc Chrystusa:

„Wychwalasz woźnicę, wołasz na woźnicę, szalejesz z powodu woźnicy. Marność jest szaleństwem zwodniczym. Powiadasz, że nie ma nic większego, nic bardziej rozkosznego. Co uczynię z takim szaleńcem? Jeśli macie litość, módlcie się za nich [...]. Cóż to za cyrkowiec? Kim jest ten, kto tak kocha owego łowcę i aktora? O czymś innym się mówi, a on zawsze o tym samym. $\mathrm{Z}$ pewnością tak jest, oczywiście cieszą nas tacy. A skoro cieszą nas tacy, to nie wpadamy w rozpacz z ich powodu. Módlmy się za takich, bracia najdrożsi [...]. On zwyciężył, okiełznał takiego konia, wychwala się, chce być niejako bogiem? Pożąda boskości, tracąc źródło bóstwa. Często się wychwala i często się myli. A dlaczego tak? Ponieważ są to zwodnicze szaleństwa. Ażeby mogli zwieść niemądrych, ażeby umiłowawszy pozór prawdy, wpadli w sidła fałszu [...]. Odzywa się do nas: nie wytrzymam, jeśli nie będę oglądał. Cóż więc uczynimy, bracia? Pozostawimy go bez przedstawienia? Umrze, nie wytrzyma, nie pójdzie za nami. Cóż zatem uczynimy? Dajmy mu przedstawienie za przedstawienie. A jakie przedstawienie urządzimy człowiekowi, chrześcijaninowi, którego pragniemy odciagnąć od tamtych przedstawień? Dzięki składam Panu Bogu naszemu, że w następnym wierszu psalmu pokazał nam, jakie powinniśmy urządzać i pokazywać przedstawienia widzom kochającym oglądanie. Oto został odciagnięty od cyrku, od teatru, od amfiteatru, ogląda się za jakimś widowiskiem, po prostu szuka. Nie pozostawimy go bez widowiska. Co mu za to pokażemy? Posłuchaj, co napisano dalej: «Panie, Boże mój, wiele rzeczy przedziwnych ty uczyniłeś». Oglądał cuda dokonywane przez ludzi, niech teraz zobaczy przedziwne rzeczy Boże. Wiele zaś przedziwnych rzeczy uczynił Pan, niechaj na nie patrzy. Dlaczego mu spowszedniały? Wychwala woźnicę, prowadzącego cztery konie, które biegną bez potknięcia się i bez upadku. A czy może podobnych cudów duchowych nie dokonał Pan? Niechaj powściąga rozwiązłość, lenistwo, niesprawiedliwość i nierozwagę, te poruszenia, które nazbyt wolno puszczone powodują wady, niechaj nimi kieruje 
i podporządkowuje sobie, niech trzyma lejce, aby się nie wyrywały. Niech je kieruje dokąd chce, byle one go nie ciagnęły, dokąd one zechcą. Wychwala woźnicę, będzie chwalony jako woźnica. Krzyczał, aby woźnicy dać płaszcz, przyobleczony zostanie w nieśmiertelność. Takie igrzyska, takie widowiska pokazuje Bóg, wołając z nieba: Oglądam was, walczcie, pomogę; zwyciężajcie, uwieńczę. «Panie, Boże mój, wiele przedziwnych rzeczy uczyniłeś, a swej troskliwości nikt nie jest do Ciebie podobny». Spójrz teraz na linoskoczka: dzięki długim ćwiczeniom ten człowiek wyuczył się chodzenia po linie, a na zwisającym utkwione są twe oczy. Ale przyglądaj się wykonawcy o wiele większych wyczynów. Tamten wyuczył się chodzenia po linie, a czy próbował chodzić po morzu? Zapomnij o swym teatrze, popatrz na naszego Piotra, nie na linoskoczka, ale, że tak powiem, na wodoskoczka. Chodź i ty nie po tej wodzie, po której chodził Piotr symbolizując coś innego, ale po innej, ponieważ cały ten świat jest morzem. Ma on szkodliwą gorycz, ma płynność utrapień i burze pokus. Ludzie są tam niczym ryby, cieszące się ze swojego nieszczęścia i niejako wzajemnie się pożerające. Tu chodź, to depcz. Chcesz oglądać widowiska, sam stań się widowiskiem! Nie ustawaj, patrz na poprzedzającego cię i mówiącego: «Staliśmy się bowiem widowiskiem dla świata, aniołów i ludzi» (1Kor 4, 9). Depcz morze, abyś nie zatonął w morzu. Nie będziesz chodził, nie potrafisz deptać, jeśli nie rozkaże ci Ten, który pierwszy chodził po morzu. Piotr bowiem prosił: «Jeśli to Ty jesteś, każ mi do siebie przyjść po wodzie» (Mt 14, 28). A ponieważ był to On, wysłuchał proszącego, udzielił się domagającemu, wezwał chodzącego i pochwycił tonącego. Takie przedziwne rzeczy uczynił Pan, im się przypatruj. Oczyma oglądającymi niech będzie wiara. Ty też czyń takie rzeczy. Ponieważ, choćby wiatry uderzyły, choćby bałwany przestraszyły i doprowadziły twą ludzką słabość do pewnego zwątpienia w uratowaniu się, możesz krzyczeć: Panie, ginę. On nie pozwoli ci zginąć, bo rozkazał, abyś chodził"116.

116 Tamże 39, 8-9, PL 36, 438-440 lub CCL 38, 430-433: „Laudas aurigam, clamas aurigae, insanis in aurigam. Vanitas est, insania mendax est [...]. Quid facio febrienti? Si est in vobis misericordia, orate pro talibus [...]. Quis est iste circissarius? Quis est iste amator et laudator illius venatoris, illius histrionis? De alio loquitur, et ille de ipso. Certe ista sunt, certe gaudemus de talibus. Si gaudemus de talibus, non desperemus de talibus. Oremus pro ipsis, fratres carissimi [...]. Ille vicit, talem equum iunxit, pronuntiat, quasi divinus vult esse: affectat divinitatem amittendo fontem divinitatis; et saepe pronuntiat, et saepe fallitur. Quare hoc? Quia insaniae mendaces sunt [...].Sit spes nostra Deus noster. Qui fecit omnia, melior est omnibus; qui pulchra fecit, pulchrior est omnibus; qui fortia, fortior est; qui magna, maior est. Quidquid amaveris, ille tibi erit. Disce amare in creatura Creatorem, et in factura Factorem [...]. Ambulare [angustam viam] non durabo, si nihil spectabo. Quid ergo facimus, fratres? Dimissuri eum sumus sine spectaculo? Morietur, non subsistet, non nos sequetur. Quid ergo facimus? Demus pro spectaculis spectacula. Et quae spectacula daturi sumus christiano homini, quem volumus ab illis spectaculis revocare? Gratias ago Domino Deo nostro: sequenti versu Psalmi ostendit nobis, quae spectatoribus spectare volentibus spectacula praebere et ostendere debeamus. Ecce aversus fuerit a circo, a theatro, ab amphitheatro, quaerat quod spectet, prorsus quaerat; non eum relinquimus sine spectaculo. Quid pro illis dabimus? Audi quod sequitur: «Multa fecisti tu, Domine Deus meus, mirabilia tua». Mirabilia hominum intuebatur, intendat mi- 
Innym proponowanym przez Biskupa Hippony widowiskiem dla chrześcijan jest między innymi, tym razem $z$ dziejów zbawienia, dramatycznie przedstawiona $\mathrm{w}$ kościele przez kaznodzieję, historia pokonania lwa-szatana przez krew Baranka oraz uwolnienie chrześcijan z mocy zła; czyni to zaś w VII homilii do Ewangelii św. Jana, wygłoszonej podczas zebrania liturgicznego w niedzielę Męki Pańskiej (23 III) 413 roku, kiedy to w mieście odbywały się równocześnie pogańskie uroczystości w świeto ku czci bogini Kybele i Attisa. Nasz Biskup ubolewa, że choć kościół jest pełny wiernych, to tym razem jest w nim mniej kobiet, bo wiele z nich, mimo iż są chrześcijankami, opuściło liturgię eucharystyczną i pobiegło, by uczestniczyć w uroczystościach ku czci bogini, podczas których niektóre składają na wadze i ważą własne złote kolczyki umaczane w swojej krwi, sprawdzając ich wartość ${ }^{117}$. Kaznodzieja wykorzystuje ten szczegół ukazując wyższość ,spektakularną” misterium chrześcijańskiego, w którym Baranek przelewa swoją krew, zwyciężając nią lwa, który rozszarpywał członki Chrystusa. Na tle tego wielkiego i krwawego widowiska, ukazanego zebranym wiernym do rozważenia, ryty bogini Kybele są tylko marnym małpowaniem, którym demon starał się daremnie przyciągnąć zwolenników Chrystusa:

„Jaki to Baranek, który zabity zabił lwa? Lwem bowiem nazwano diabła, który kraż̇y i szuka, kogo by pożarł (1P 5, 8). Lew krwią Baranka został zwyciężony - oto widowiska chrześcijan! A co więcej: oni oczami ciała widzą tylko próżność, a my oczami serca - prawdę. Nie sądźcie, bracia, że nasz Pan Bóg pozostawił nas bez widowisk; jeśliby nie było żadnych widowisk, to pocoście się dziś tu zgromadzili? Co bowiem opowiedzieliśmy, zobaczyliście i okrzyczeliście; nie oklaskiwalibyście, gdybyście nie widzieli. Wielką to rzeczą jest oglądać po całym świecie lwa zwyciężonego krwią Baranka oraz wydobyte z zębów lwów członki Chrystusa i dołączone do ciała Chrystusowego"118.

rabilia Dei. Multa fecit Dominus mirabilia sua: haec respiciat. Quare illi viluerunt? Aurigam laudat regentem quattuor equos, et sine labe atque offensione currentes: forte talia miracula spiritualia non fecit Dominus? Regat luxuriam, regat ignaviam, regat iniustitiam, regat imprudentiam, motus istos qui nimium lapsi haec vitia faciunt, regat et subdat sibi, et teneat habenas, et non rapiatur; ducat quo vult, non trahatur quo non vult. Aurigam laudabat, auriga laudabitur, clamabat ut auriga veste cooperiretur, immortalitate vestietur. Haec munera, haec spectacula edit Deus. Clamat de coelo: specto vos, luctamini, adiuvabo, vincite, coronabo [...]. Nunc specta histrionem. Didicit enim homo magno studio in fune ambulare et pendens te suspendit. Illum attende editorem maiorum spectaculorum. Didicit iste in fune ambulare, numquid fecit in mari ambulare? Obliviscere theatrum tuum, attende Petrum nostrum, non funambulum, sed, ut ita dicam, mariambulum [...]. Spectare vis, esto spectaculum, ne deficias [...]. Haec mirabilia fecit Dominus, ipsa intuere; oculus spectantis fides sit. Et fac tu talia [...]", PSP 38, 92-94.

117 Por. tenże, In Joannis evangelium tract. 7, 2, CCL 36, 68, thum. W. Szołdrski, PSP 15/1, Warszawa 1977, 114-115; Lugaresi, Il teatro di Dio, s. 678-679.

118 Tamże 7, 6, CCL 36, 70: „Sanguine Agni victus est leo. Ecce spectacula christianorum. Et quod est amplius, illi oculis carnis vident vanitatem, nos cordis oculis veritatem. Ne putetis, fratres, quod sine spectaculis nos dimisit Dominus Deus noster; nam si nulla sunt spectacula, cur 
Nie trudno zauważyć, że dla Augustyna, podobnie jak wcześniej dla Jana Chryzostoma na Wschodzie, widowiskiem chrześcijańskim jest również zgromadzenie liturgiczne, podczas którego kaznodzieja objaśnia i komentuje jakąś prawdę wiary lub wydarzenie biblijne, a wierni mogą prowadzić z nim dialog, aprobując lub nie jego słowa, czy też przyjmując je z radością i głośnym aplauzem, jak w teatrze. Są to zawsze, jak zaznaczaliśmy wyżej, widowiska przede wszystkim duchowe, dla zmysłów niewidzialne, wymagające od słuchaczy nie tylko dobrej znajomości prawd wiary i mocnej ich wiary, ale także ich dużej, sterowanej przez kaznodzieję, wyobraźni; stąd też nie mogą ich oglądać poganie, bo „oni - jak stwierdza nasz Autor - oczami ciała widzą tylko próżność, a my oczami serca - prawdę". W powyższym przypadku Kaznodzieja położył nacisk na oglądanie (spectare): wierni, którzy przyszli do kościoła wybierając zebranie liturgiczne, ucieszyli się, jego zdaniem, widowiskiem o wiele piękniejszym i większym, niż ci, którzy poszli ogląać uroczystości ku czci Kybele; oczami serca, wspartymi przez wiarę, oglądali bowiem treści podsunięte przez słowo Boże, które jest fundamentem, na którym konstruowane jest często przez egzegetę, jak zaznaczono wyżej, widowisko chrześcijańskie w wyobraźni wiernego. Zadaniem bowiem komentatora w przepowiadaniu homiletycznym jest również, według Augustyna, ,uwidowiskowianie" lub „uscenawianie” słowa Bożego lub wydarzeń biblijnych tak, żeby każdy mógł je zrozumieć i przyjąć w swoim wewnętrznym teatrze; kaznodzieja używa przy tym nierzadko terminologii widowiskowej, posługując się czasownikami; spectare, videre, intueri, albo też nazywając komentowane wydarzenie biblijne wprost widowiskiem czy przedstawieniem (spectaculum) lub teatrem, a występujące w nim postacie - aktorami. To przejście od wysłuchania do wizji poprzez opracowanie retoryczne homilii jest wielokrotnie przez niego poświadczone: odczytanie w kościele jakiegoś epizodu lub passusu biblijnego, oraz jego objaśnienie, wywołują w wyobraźni słuchaczy mechanizm myślowego przedstawienia sobie tej sceny, która zdaje się ożywać, uobecniać i żyć tak, iż zdają się czuć jego świadkami i uczestnikami. Tak np. słuchacze Augustyna zdają się być naocznymi świadkami widowiska (spectaculum), jakim jest cud wskrzeszenia Łazarza, odważnej postawy Piotra po zesłaniu Ducha Swiętego, czy ukrzyżowania Chrystusa, które, podobnie jak Jan Chryzostom, nazywa ,wielkim widowiskiem” (grande spectaculum):

„Słuchaliśmy z podziwem, jakby o widowisku wielkiego cudu na naszych oczach przedstawionym, gdy czytano Ewangelię, jak z powrotem ożył Łazarz"119.

\footnotetext{
hodie convenistis? Ecce quod diximus, vidistis, et exclamastis; non exclamaretis, nisi vidissetis. Et magnum est hoc spectare per totum orbem terrarum victum leonem sanguine Agni, educta de dentibus leonum membra Christi et adiuncta corpori Christi”, por. thum. PSP 15/1, 117.

119 Tamże 49, 2, CCL 36, 420: „Admirantes audiebamus, tamqam magni miraculi spectaculo ante nostros oculos constituto, cum Evangelium legeretur, quemadmodum revixerit Lazarus", por. tłum. PSP 15/2, 30; por. Lugaresi, Il teatro di Dio, s. 679.
} 
„Jeśli komuś sprawia przyjemność oglądanie takiego świętego widowiska, niech czyta Dzieje Apostolskie, i jeśli ubolewał nad zapierającym się błogosławionym Piotrem, niech go teraz podziwia. Tam zobaczy, jak ów język przemieniony pobudzał od nieufności do ufności i od niewolnictwa do wolności $[\ldots]$, a przecież ten język przedtem jednemu językowi nie zdołał się oprzeć i zaparł się Go" "120.

„Szedł więc Jezus na miejsce, gdzie miał być ukrzyżowany, niosąc swój krzyż. Wielkie widowisko (Grande spectaculum): jeśli na nie patrzy bezbożność - wielkie pośmiewisko; jeśli pobożność - wielka tajemnica; jeśli patrzy bezbożność - wielkie świadectwo hańby; jeśli pobożność - wielki pomnik wiary; jeśli pobożność - wielki pomnik wiary; jeśli patrzy bezbożność - to śmieje się z króla, który jako berło królewskie niesie drzewo swej kaźni; jeśli pobożność - to widzi króla niosącego drzewo, aby go na nim przybito, a które potem i na czołach królów miało być umieszczane; na nim wzgardzony w oczach bezbożnych, którym serca świętych chlubić się miały"121.

Nie trudno zauważyć w ostatniej wypowiedzi, zwłaszcza w jej brzmieniu oryginalnym, retoryczny zestaw i grę słów: ludibrium - spectaculum - mysterium, oraz ich przeciwieństw: impietas - pietas, którymi Autor nasz, podobnie jak Jan Chryzostom, w krótkich i urywanych zdaniach, wygłaszanych zapewne z przerwami, chciał jak najbardziej udramatyzować to „wielkie widowisko", jakim było ukrzyżowanie Chrystusa, a także wpłynąć na wyobraźnię swych słuchaczy.

Takich widowisk wewnętrznych, powstających w wyobraźni słuchaczy podczas czytania, medytowania lub komentowania Pisma Świętego, wskazuje Augustyn o wiele więcej: jest nim m. in. epizod o czystej Zuzannie (Dn 13, 1-64), stanowiący malowniczą scenę teatru wewnętrznego ${ }^{122}$, takie widowisko duchowe stanowi też epizod o adoracji Magów (Mt 2, 1-12), której postacie

${ }^{120}$ Tamże 92, 2, CCL 36, 557: „Si quem delectat tam suaviter sanctum tale spectaculum intueri, Actus Apostolorum legat; ibi beatum Petrum quem negantem doluerat, stupeat praedicantem", por. thum. PSP 15/2, 211.

${ }^{121}$ Tamże 117, 3, CCL 36, 652: „Ibat ergo ad locum ubi fuerat crucifigendus, portans crucem suam Jesus. Grande spectaculum! Sed si spectet impietas, grande ludibrium; si pietas, grande mysterium; si spectet impietas, grande ignominiae documentum; si pietas, grande fidei munimentum; si spectet impietas, ridet regem pro virga regni lignum sui portare supplicii; si pietas, videt regem baiulantem lignum ad semetipsum figendum, quod fixurus fuerat etiam in frontibus regum; in eo spernendus oculis impiorum, in quo erant gloriatura corda sanctorum", PSP 15/2, 334; por. też De civitate Dei XVII 17, ed. B. Dombart - A. Kalb, CCL 48, Turnhout 1955, 583, thum. W. Kornatowski: Św. Augustyn, O państwie Bożym, II, Warszawa 2003, 445: „Tymi słowy (Ps 21, 19) wskazał naturalnie na ciało swe rozciagnnięte na krzyżu, na przytwierdzone i przebite gwoździami ręce i nogi, przez co stał się widowiskiem (spectaculum) dla tych, którzy Mu się przypatrywali i napawali Jego widokiem”.

${ }^{122}$ Por. tenże, Sermo 345, 5, PL 39, 1508: „Intuebamur Susannam tentatam a viris concupiscentibus eius corruptionem, intuebamur certantem. Lectio illa theatrum nostri cordis erat, athletam Dei pudicum spiritum exspectabamus, certantem adversarium videbamus, de victo cum victrice triumphemus". 
odgrywają niejako rolę na scenie przed żłóbkiem Chrystusa ${ }^{123}$, takim ,godnym politowania widowiskiem" (spectaculum miserabile) są również słuchacze słowa Bożego, nie wypełniający jego nakazów, budujący nie na skale, ale na piasku (Mt 7, 24-27) ${ }^{124}$; takim widowiskiem jest także walka ze swymi wadami i pożądliwościami ${ }^{125}$.

Nie mało barwnych treści, do tworzenia w wyobraźni słuchaczy wewnętrznych przedstawień, dostarczały także według Augustyna, podobnie jak u Jana Chryzostoma, Passiones męczenników, które czytywane były publicznie w kościele podczas zebrań liturgicznych w doroczne ich wspomnienia; poświadczają to nie rzadko kazania Biskupa Hippony ku ich czci przy tej okazji wygłaszane, w których tego rodzaju wewnętrzne przedstawienia, unaoczniające ich męczeństwo, nazywał również wprost widowiskami (spectacula), jak np. we wspomnienie Perpetuy i Felicyty oraz św. Szczepana ${ }^{126}$. Miały one

${ }^{123}$ Por. tenże, Sermo 373, 5, PL 39, 1665: „Juvat intueri omnia, et in unum adducta conspectum, animo cernere spectacula spiritualia. Nascitur Christus: virgo concipit, virgo parit, virgo nutrit [...]. Angeli anuntiant, pastores glorificant, coeli enarrant, Magi desiderant, reges formidant, Judaei demonstrant, gentes adorant"; Sermo 139A, 1-3, PL 39, 2018.

${ }^{124}$ Por. tenże, Sermo 179, 8, PL 38, 971: „Ergo super arenam, qui audit et non facit, aedificat: [...].Spectaculum miserabile!".

${ }^{125}$ Por. tenże, Sermo 9, 13, PL 38, 85A: „ «Qui docet manus meas ad proelium et digitos meos ad bellum» (Ps 143, 1). Est enim bellum, quod secum agit homo, dimicans contra concupiscentias malas, frenans avaritiam, elidens superbiam, suffocans ambitionem, trucidans libidinem. Has pugnas facis in occulto, et non vinceris in aperto. Ad hoc docentur manus vestrae ad proelium et digiti vestri ad bellum. Non est hoc in spectaculis vestris. In illis spectaculis non id est venator, quod citharista; aliud agit venator, aliud citharista: in spectaculo Dei unum est [...]. Non vos delectant talia spectacula, ubi non promeremur oculos editoris, sed oculos Redemptoris"; Sermo 335, 3, PLS 2, 818 lub NBA 33, 934: „Hic ergo certamen est, haec vita Deo spectanti theatrum est: hic pugna, hic conflictus cum omnibus vitiis, et maxima cum principe vitiorum, tamquam cum Golia. Diabolus enim animam provocat quasi ad singulare certamen [...]. Memento te pugnare. Invisibilis est hostis, sed invisibilis est et Protector tuus. Non vides cum quo confligis, sed credis in Eum, a quo protegeris"; Sermo 313, 7, 10, ed. A. Quacquarelli - M. Recchia, NBA 33, Roma 1986, 734: „Dostrzeż swego nieprzyjaciela, rozpoznaj z jakim nieprzyjacielem walczysz w teatrze twego serca. Teatr jest ciasny, lecz to Bóg widzi: tam ujarzmij swego nieprzyjaciela (Agnosce cum qua pugnas in theatro pectoris tui. Angustum theatrum, sed Deus spectat. Ibi doma inimicam tuam = iram); NBA 33, 736: „Niech Bóg będzie obecny w waszych codziennych walkach, aby wam pomagal, ponieważ oglądaliście walkę męczennika Szczepana, oglądaliście jak zwyciężał, obyście i wy tak zwyciężali w waszych sercach”.

${ }^{126}$ Por. tenże, Sermo 280, 1-2 i 4 (In Natali Perpetuae et Felicitatis), PL 38, 1281 i 1282 lub NBA 33, 98 i 102: „Hodiernus dies anniversaria replicatione nobis in memoriam revocat, et quodam modo repraesentat diem, quo sanctae famulae Dei Perpetua et Felicitas coronis martyrii decoratae, perpetua felicitate floruerunt, tenentes nomen Christi in proelio [...]. Quid hoc spectaculo suavius? Quid hoc certamine fortius? Quis hac victoria gloriosius? Tunc cum bestiis sancta obicerentur corpora, toto amphitheatro fremebant gentes, et populi meditabantur inania [...]. Nam ubi erat illa femina, quando ad asperrimam vaccam se pugnare non sensit, et quando futurum esset quod iam fuerat, inquisivit? Ubi erat? Quid videns, ista non viderat? Quo fruens, ista non senserat? Ouo amore alienata, quo spectaculo avocata, quo poculo inebriata?"; Sermo 315, 5 i 7, NBA 33, 728 i 730: „Wysłuchaliście i oglądnęliście widowisko serca (Auditis et spectacula cordis vidistis). Dźwięk był w uszach, a wizja w umysłach. Oglądaliście wielki agon św. Szczepana, w którym został on ukamie- 
jednak nie tyle zaspokajać u wiernych, przywykłych do oglądania widowisk kaźni i śmierci w amfiteatrach, pragnienie oglądania, ale przede wszystkim dostarczać im przykładów do naśladowania:

„Wykorzeń w sobie żądzę oglądania widowisk. Kościół podsuwa twemu umysłowi widowiska godniejsze i czcigodniejsze (exhibet Ecclesia menti tuae honorabiliora et veneranda spectacula). Dopiero co przeczytano Passio św. Cypriana: wysłuchaliśmy uszami, wyobrażaliśmy go sobie w myśli i oglądaliśmy w walce, a nawet w pewien sposób baliśmy się o jego los, ale ufaliśmy w pomoc Bożą. Czy chcecie wiedzieć, jaka jest różnica między naszymi widowiskami a teatralnymi (quid intersit inter spectacula nostra et theatrica)? My, o ile mamy trzeźwy umysł, męczenników, których oglądamy, pragniemy naśladować; powtarzam, że my męczenników, których podziwiamy, pragniemy naśladować. Szlachetny widzu, gdy bywasz w teatrach, byłbyś szalony, gdybyś się odważył naśladować jakiegoś aktora, którego może kochasz, a nawet podziwiasz. Ja natomiast podziwiam Cypriana i kocham Cypriana. Jeśli cię to dziwi lub złości, przeklnij mnie i powiedz: «Bądź sobie takim, jak on». Owszem, ja go oglądam, podziwiam i na ile mogę, obejmuję ramionami swego umysłu. Podziwiam go w walce i cieszę się z jego zwycięstwa. Możesz się złościć, jak powiedziałem, i mówić mi: «Bądź sobie takim», ale patrz, czy go nie obejmuje, patrz, czy go nie podziwiam, patrz, czy go nie pragnę, patrz, czy nawet godny jestem to mówić, ale nie mogę tego nie czynić. Podziwiaj i ty [swego aktora] i kochaj go. Nie gniewaj się, jeśli ci powiem: «I ty takim bądź». Powstrzymam się jednak i nie powiem tego, uznaj we mnie przyjaciela i zmień widowiska. Kochajmy takich, których nie musimy się wstydzić, kochajmy takich, których w miarę możności chcemy naśladować, lecz jeśli ten, który jest oglądany, jest człowiekiem okrytym hańbą, to czy ten, który go ogląda, może być szanowany? Pozbądź się więc żądzy oglądania człowieka, który sprzedaje niemoralność. Oglądając niesławę, zgadzasz się i na niemoralność. Dlaczego pragniesz tego, co potępiasz? Dziwiłbym się, gdyby infamia twego ulubieńca nie dosięgła i ciebie. Niech cię jednak nie dosięgnie, niech twoja uczciwość, jeśli można, pozostanie niesplamiona. Czy się odważę zabronić ci widowisk (audeo tibi prohibere spectacula)? Mam odwagę zabronić, oczywiście, że mam odwagę. Dodaje mi do tego ufność to miejsce oraz ten, który mnie w tym miejscu postawił. Święty Męczennik mógł przeżyć tyle okrucieństw ze strony pogan, a ja miałbym się nie odważyć pouczać słuchających chrześcijan? Ja mam się bać skrytych obelg, gdy on pogardził otwartym szaleństwem pogan? Powiem wprost, jeśli mówię nieprawdę, to z pewnością nie uzyskam aprobaty w sercach słuchaczy"127.

\footnotetext{
nowany (Sonus erat in auribus, visio in mentibus. Spectastis magnum agonem sancti Stephani, qui in agone lapidabatur) [...]. Wielkie Boże widowiska (Magna divina spectacula)".

${ }^{127}$ Tenże, Sermo 313A, 3, NBA 33, 482, 864-866.
} 
„Oglądaliśmy przed chwila wielką walkę (Modo spectavimus magnum certamen) siedmiu braci i ich matki. Cóż to była za walka, moi bracia, jeśli tylko nasze umysły potrafiły ją sobie wyobrazić (si noverunt mente nostras spectare). Porównajcie z tym świętym widowiskiem przyjemności i uciechy teatrów (Comparate huic sancto spectaculo voluptates et delicias theatrorum), tam oczy się plamią, tu serca oczyszczają, tu widz jest nawet godny pochwały, jeśli będzie naśladowca, tam zaś i widz jest nieprzyzwoity i naśladowca zniesławiony. Ostatecznie, ja kocham męczenników i oglądam męczenników, kiedy czytane są Passiones męczenników (quando leguntur Passiones martyrum, amo martyrum, specto martyrum). Jeśli mi powiesz: «Takim sobie bądź, jak oni», to mnie pochwaliłeś. Ty oglądaj sobie mima lub pantomima, a jeśli ci powiem: «Takim sobie bądź, jak on», to nie chciej sie obrażać, potępiają cię bowiem nie moje słowa, lecz reakcja twego gniewu. Obrażając się osądzasz siebie samego: oto co kochasz, a tym nie chcesz być. Wydało mi się rzeczą odpowiednią w obliczu widowiska świętych Machabejczyków (de spectaculo sanctorum Machabeorum), których wspomnienie zwycięstwa dziś obchodzimy, przypomnieć wam o skutkach oglądania widowisk teatralnych"128.

Takich spektakularnych i godnych naśladowania treści dostarczały liczne opisy męczeństw męczenników, m.in. Passio św. Wincentego, któremu nasz Biskup poświęcił w latach 410-412 kilka kazań. Oto ich odpowiednio wybrane fragmenty:

„Oczami wiary oglądaliśmy wielkie widowisko zwyciężającego wszędzie męczennika świętego Wincentego (Magnum spectaculum spectavimus oculis fidei martyrem sanctum Vincentium ubique vincentem). Zwyciężył w mowie, zwyciężył podczas katowania, zwyciężył w wyznawaniu [wiary], zwyciężył w udręce, zwyciężył palony ogniem, zwyciężył topiony w falach, zwyciężył wreszcie połamany i zamordowany. Kiedy jego ciało, w którym widniał sztandar Chrystusa Zwycięzcy, wrzucane było z łódki do morza, milcząco mówił: «Powalają nas, lecz nie giniemy» (2Kor 4, 9). Któż taką wytrzymałością obdarzył swego żołnierza, jeśli nie Ten, który za niego wcześniej przelał krew [...]. Wielka walka gotuje wielką chwałę, nie ludzką ani doczesna, lecz boską i wieczną. Wiara walczy, a kiedy wiara walczy, nikt nie pokona ciała, ponieważ chociażby było pocięte i poszarpane, gdy ginie, [jego właściciel] jest odkupiony krwią Chrystusa [...]. Wysłuchaliśmy długiego czytania, a dzień jest krótki, także długim kazaniem nie powinniśmy nadużywać waszej cierpliwości. Wiem, że słuchaliście cierpliwie, długo stojąc i słuchając, jakbyście współcierpieli z męczennikiem"129.

„Duch nasz doznał wrażenia wielkiego i godnego niezwykłego podziwu widowiska (Magnum et multum mirandum spectaculum noster animus cepit).

\footnotetext{
128 Tenże, Sermo 301A, 7, NBA 33, 482-484.

129 Tenże, Sermo 274, 1, NBA 33, 12-14 lub PL 38, 1252-1253.
} 
Gdy czytano słynny opis męczeństwa św. Wincentego (cum beati Vincentii gloriosa passio legeretur), doznaliśmy oczami ducha nie czczej i zgubnej, jak zwykle w teatrach przyjemności słuchania bajek, ale wielce pożytecznej i owocnej. Można było oglądać (videre) niezwyciężonego ducha męczennika w konfrontacji z zasadzkami starego wroga, z okrucieństwem bezbożnego sędziego i cierpieniami śmiertelnego ciała, zmagającego się w ostrej walce i pokonującego wszystko z pomocą Pana [...]. Jakich pytań wysłuchał, jakie dawał odpowiedzi i jakie cierpienia przezwyciężył, przypomniało nam wysłuchane czytanie (decursa lectio) i nam jakby naocznie (tamquam in conspectu) przedstawiło, co się wtedy działo"130.

„Chrystus nakazuje uroczyście celebrować, a nie tylko opieszale (segniter) opowiadać, bardzo dzielne i słynne męczeństwo św. Wincentego. Widzieliśmy w duchu i oglądaliśmy w myśli (vidimus animo et cogitatione conspectimus), co przeżył, co usłyszał, co odpowiadał i w jaki sposób przed naszymi oczyma odbyło się przedziwne widowisko (et quodammodo ante oculos nostros mirandum spectaculum constitutum est): niegodziwy sędzia, krwawy kat, niezłomny męczennik oraz walka między okrucieństwem a wiarą: stąd szaleństwo i stąd zwycięstwo. Gdy w naszych uszach rozbrzmiało czytanie (lectione personante in auribus nostris), w naszych sercach rozpaliła się miłość; chcielibyśmy, o ile by to było możliwe, przytulić i ucałować owe poszarpane członki, które dostatecznie oparły się tak wielkim katuszom, i nie chcielibyśmy, żeby były aż tak katowane. Któż bowiem chciałby oglądać srożącego się oprawcę i człowieka pozbawionego człowieczeństwa, szalejącego przeciw ciału ludzkiemu [...]. Jednakże w tym samym widowisku (in eodem ipso uno spectaculo) różnimy się z prześladowcą motywami: jego cieszyło potępienie męczennika, a nas przyczyna; jego to, co wycierpiał, a nas dlaczego cierpiał; jego katusze, a nas dzielność; jego rany, a nas nagroda; jego, że bardzo długo był męczony, a nas, że katuszami nie został złamany" ${ }^{\prime 131}$.

Wszystkie one, jak widać, opowiadają o oglądaniu i przeżywaniu wytworzonego w wyobraźni słuchaczy po lekturze Passio martyris wewnętrznego widowiska katowania aż do śmierci danego męczennika, który ją odważnie ponosi za wiarę w Chrystusa.

Widowiskiem chrześcijańskim jest wreszcie również dla naszego Biskupa, podobnie jak dla omówionych wyżej autorów, szczęście wieczne w niebie; nie opisuje on go jednak w tym kontekście zbyt szczegółowo i obrazowo, ale skupia się głównie na jednym jego wewnętrznym detalu - że będzie tam panował przedziwny wieczny pokój, przeżywany wspólnie z aniołami:

${ }^{130}$ Tenże, Sermo 275, 1, PL 38, 1254 lub NBA 33, 16 (wygłoszona we wspomnienie św. Wincentego 22 I 411 r.).

${ }^{131}$ Tenże, Sermo 277A, 1, PLS 2, 417 lub NBA 33, 54-55. 
„O pokoju ów, jaki ujrzymy w Bogu! O owa święta równości z aniołami! O owa przepiękna wizjo i przecudne widowisko"(spectaculum pulchrum)!"'132

„Pokój jest niewidzialny. Jakież to oko go dostrzeże, żeby umiłować? [...]. Oto widowiska rzeczy niewidzialnych, jakie okazuje Bóg. Jakąż pięknością zrozumienia sprawy pokoju, uderzył wasze serca"133.

„Jak Jeruzalem znaczy wizja pokoju, tak Syjon znaczy spekulacja czyli widzenie i kontemplacja. Nie wiem, jak wielkie widowisko (magnum spectaculum) jest nam przyobiecane i to przez samego Boga założyciela miasta"134.

Także temat widowisk niebieskich (spectacula coelestia) nie ma szerszego rozwinięcia w tekstach augustyńskich, gdzie występuje raczej rzadko, jako zjawisko nie do opisania ${ }^{135}$, a w nielicznych jego o nich wypowiedziach, porównywane są do oczekiwanych przez ludzi voluptates terrenae, te zaś ponieważ są przemijające, Bóg oferuje jako wieczne ich trwanie i przeżywanie ${ }^{136}$. Tam będzie jednak inaczej, niż w widowiskach ziemskich, gdzie widz i aktor stanowią dwie odrębne rzeczywistości, a tu w niebiańskich - szczęście widza będzie odbiciem szczęśliwości Boga, który jest kontemplowany w akcie miłości i pełnego zjednoczenia oraz uwielbiany jako jedno wspólne chrześcijańskie widowisko i jedyny uszczęśliwiający nie kończący się nigdy pokój oraz jedno przewyższające wszystkie doczesne przyjemności szczęście ${ }^{137}$.

132 Tenże, Enarrationes in PS. 136, 5, PL 37, 1764 lub CCL 40, 1967: „O pax illa quam videbimus apud Deum! O illa sancta aequalitas angelorum! O illa visio et spectaculum pulchrum”, PSP $42 / 1,148$.

${ }^{133}$ Tamże 147, 15, PL 37, 1923 lub CCL 40, 2149: „Haec sunt spectacula quae exhibet Deus rerum invisibilium. Quanta pulchritudine intellectus pacis corda vestra percussit", PSP 42/1, 351.

${ }^{134}$ Tamże 64, 3, CCL 39, 825, PSP 39, 101; por. tamże 146, 4, CCL 40, 2124, PSP 42, 322: „Cóż znaczy Izrael - Widzący Boga. Otóż wszyscy obywatele tego miasta, widząc Boga radują się w tym olbrzymim mieście rozległym i niebieskim. Widowiskiem (spectaculum) dla nich jest sam Bóg”; zob. Lugaresi, Il teatro di Dio, s. 687.

${ }^{135}$ Por. Augustinus, Enarrationes in Ps. 36, 2, 8, CCL 38, 352, PSP 38, 8: ,Zapewniono nam słodkie widowisko, nie do opisania zgoła. A chociaż cześsciowo, niejako w zwierciadle, można coś sobie na ten temat pomyśleć, to jednak w żaden sposób niepodobna tego wypowiedzieć, ani jego piękności, ani słodyczy, jaką zastrzegł Bóg dla tych, co się Go boją i udzielił w nim nadzieję w Nim pokładającym. Niechaj na to przygotują się serca nasze pośród wszystkich utrapień i pokus obecnego życia”.

${ }^{136}$ Por. tamże 26, 2, 8, CCL 38, 158, PSP 37, 203: „Oto, co miłuję, oto, co pragnę: zamieszkać w domu Pańskim po wszystkie dni życia mego. Tam mnie czeka wielkie widowisko - wpatrywanie się z podziwem w piękności Pańskie".

${ }^{137}$ Por. tamże 84, 10, CCL 39, 1170, PSP 40, 82: „Wspólnym widowiskiem dla nas będzie Bóg; wspólną własnością Bóg; ogólnym pokojem Bóg (Commune spectaculum habebimus Deum; communem posessionem habebimus Deum; communem pacem habebimus Deum)"; tamże 96, 1, CCL 39, 1354, PSP 40, 279: „Sercu chrześcijanina Bóg przedstawi wielkie widowiska, ponad które niczego milszego znaleźć niepodobna, pod warunkiem, że posiadamy podniebienie wiary, które może zasmakować miodu Bożego"; tamże 147, 3, CCL 40, 2141, PSP 42, 341: „Moi bracia, jakież to będzie widowisko w oglądaniu Boga?”; tamże 32, 2, 25, CCL 38, 271, PSP 37, 320: „Oglądamy rzeczy piękne, ale i Piękny nas ogląda [...]. Cieszy nas to widowisko. A któż jest tym, który patrzy 
Oprócz opisywania mniej lub więcej szczegółowo widowiska, powstającego w wyobraźni chrześcijanina, Augustyn czynił też niekiedy drobne aluzje lub odniesienia do widowiska wewnętrznego, które tworzyło się w jego myśli podczas komentowania tekstu biblijnego, który każdy słuchacz na swój sposób starał się zrozumieć i zastosować u siebie ${ }^{138}$; innym znów razem zachęcał słuchaczy do wytworzenia sobie w wyobraźni w oparciu o komentowany tekst przedstawienia wewnętrznego objaśnianej prawdy, dostarczając do tego niemal reżyserskich wskazówek, jak np. do wyobrażenia sobie sceny gniewu człowieka niegodziwego i cierpliwości człowieka sprawiedliwego przy komentowaniu wersetu psalmu, mówiącego o ogniu poprzedzającym Boga i spalającym dookoła Jego nieprzyjaciół ${ }^{139}$.

Korzyścią i zachętą do wybierania i oglądania widowisk chrześcijańskich jest według Biskupa Hippony także to, że jeżeli w pogańskich widowiskach publicznych jakiś znany i uwielbiany aktor lub zawodnik, dla którego z miłości do niego wielu widzów przyszło, by go oglądać i podziwiać, przegra swój występ, to jego wielbiciele doznają często ze strony innych wiele przykrych drwin i szyderstw, co się nigdy nie zdarza podczas przedstawień chrześci-

na nas? (Spectemus pulchra, et a pulchro spectemur. Spectemus nos mente ea quae dicuntur in sensibus divinarum Scripturarum, et gaudeamus tali spectaculo. Spectatur autem noster quis est?) Oto oczy Pańskie".

${ }^{138}$ Por. np. tamże 34, 2, PL 36, 323 lub CCL 38, 300-301, PSP 37, 350: „Wielkie to widowisko zobaczyć Boga uzbrojonego w twej obronie (Magnum spectaculum est videre Deum armatum pro te). A co jest Jego puklerzem? Jaka broń? [...]. Jego bronią, jaką nie tylko nas ochrania, lecz również uderza w nieprzyjaciół, będziemy my, jeśli będziemy iść słuszną drogą [...]. Rzecz jasna, jest to broń niewidzialna, duchowa i niezwyciężona, ponieważ zwalczamy wrogów duchowych (Armavit nos armis [...] invictis spiritualibus sane atque invisibilibus, quia et hostes invisibiles expugnamus). Uzbrojeni zostajemy wiarą w te rzeczy, których nie widzimy i obalamy niewidzialnych nieprzyjaciół [...]. A więc sama wiara może być pancerzem i tarczą"; tamże 36, 2, 8, PL 36, 368 lub CCL 38, 352, PSP 38, 8: „Zapewniono nam zatem, nie wiem jak słodkie widowisko (Servatur ergo nobis nescio quod dulce spectaculum)"; zob. Lugaresi, Il teatro di Dio, s. 679.

${ }^{139}$ Por. Augustinus, Enarrationes in Ps. 96, 6, PL 37, 1241 lub CCL 39, 1358, PSP 40, 284: „Kiedy widzimy dwóch, jednego rozgniewanego, drugiego cierpliwie znoszącego, do was należy osądzić, który z nich płonie. Takie widowisko możecie zobaczyć i odnośnie rodzaju ludzkiego (Potestis in genere humano tale spectaculum contueri). Postawcie sobie przed oczami człowieka niegodziwego, którego umysł jest wzburzony, twarz surowa, oczy płonące, ciskającego słowa zmierzające do zguby człowieka, do rabunku, do skrzywdzenia i obrazy, który nie potrafi się powstrzymać i opanować; drugiego cierpliwie słuchającego słów, znoszącego razy, bez względu na to, ile mu przypadnie znieść i nadstawiającego policzek bijącemu. Kiedy widzisz z jednej strony furię, z drugiej łagodność; z tamtej gniew, z tej cierpliwość; z tamtej płomienie, z tej tolerowanie; czy będziesz miał wątpliwości, który z nich płonie, a który znosi?”; nie mniej dokładne reżyserskie wskazówki zob. tenże, Sermo 299D, 4 (= Denis 16) [aluzja do procesu męczenników scylitańskich], NBA 33, 418: „Postawcie sobie przed oczy agon męczenników. Oto przychodzi nieprzyjaciel i zmusza ich do wyrzeczenia się Chrystusa. Lecz przedstawmy go sobie jeszcze obiecującego, a nie grożącego: obiecuje bogactwa i zaszczyty. Są to rzeczy zbyteczne, a ci, którzy takimi darami są kuszeni do wyrzeczenia się Chrystusa, jeszcze nie znali agonu, jeszcze nie doświadczyli walki, jeszcze nie zostali sprowokowani do prawdziwej i właściwej walki przez przez starego nieprzyjaciela". 
jańskich, bo uczestniczy w nich Chrystus, który nie zawodzi, ale zawsze zapewnia zwycięstwo i nie można się Go nigdy wstydzić, a widzowie przyszli z miłości do Niego:

„Pokażcie ludziom, co Chrystus potrafił uczynić na całym okręgu ziemi, mówiąc im i doprowadzając ich do Jego umiłowania. Iluż to dzisiaj poprowadziło swoich przyjaciół albo na przedstawienie pantomimy, albo na popisy muzyczne? Dlaczego, jeśli nie z miłości do artysty? Wy też kochacie Chrystusa. Ten, który zwyciężył świat, wystawił tak wielkie widowiska, że nikt nie może Mu niczego zarzucić, ani znaleźć coś negatywnego do powiedzenia. Wszak i w teatrze czasami aktor, którego się lubi, zostaje w nim pokonany. Nikt natomiast nie pokonał Chrystusa: nie ma się zatem czego wstydzić. Chwytajcie więc, przyprowadzajcie, przyciagajcie, kogo możecie [ na nasze widowiska] oraz bądźcie spokojni, przywodzicie ich bowiem do Tego,który nie nuży się patrzącym oraz proście Go, aby ich oświecił, żeby oglądali, jak należy"140.

„Będzie się cieszył w taki sposób, iż nie będzie się obawiał, że zostanie zwyciężony ten, kogo kocha. Kocha bowiem woźnicę, a gdy ten zostanie zwyciężony, spotkają go szyderstwa. Kiedy zaś woźnica zwycięży, on tylko zostanie udekorowany $[\ldots]$ za zwycięzcę biedak jest wyśmiany. Dlaczego za niego znosisz wyrzuty, skoro razem z nim nie dzielisz się szatą zwycięstwa? Inaczej jest na naszych widowiskach"141.

Na zakończenie naszych rozważań o chrześcijańskich widowiskach zastępczych, proponowanych przez św. Augustyna, warto przytoczyć fragment jego kazania, wygłoszonego w 417 r. na Boże Narodzenie, który L. Lugaresi nazwał „małą sumą jego myśli o widowiskach”142, a wyjątkowo ciekawy z tej racji,

${ }^{140}$ Tenże, Enarrationes in PS. 96, 10, PL 37, 1244 lub CCL 39, 1362: „,vos amate Christum. Tanta enim spectacula praebuit, in quo nemo potest dicere aliquid se reprehensionis invenire, ille qui vicit saeculum. Nam et aliquando quem amat quisque in theatro, vincitur in illo. Nemo vero vincitur in Christo: non est de quo erubescere".

141 Tamże 39, 11, PL 36, 441, CCL 36, 433: ,amat enim aurigam, quo victo insultationes ferat. Quando vincit auriga, ipse vestitur [...]. Quare pro illo percipis reprehensionem, cum quo non dividis vestem? Hac aliud in spectaculis nostris", por. PSP 38, 95; zob. tamże 53, 10, PL 36, 626 lub CCL 39, 653-654, PSP 38, 322: „Chwaląc Boga, nie będę się wstydził. Nie tak, jak miłośnicy rozrywek amfiteatralnych sławią woźnicę, pogromcę zwierząt, czy jakiegoś tancerza czy linoskoczka, a ich entuzjazm zachęca innych chwalców do wspólnego okrzykiwania. I chociażby wszyscy kibice krzyczeli, wszyscy najczęściej się wstydzą, kiedy ich zawodnik zostanie pokonany. Nie tak rzecz się przedstawia z naszym Bogiem (non ita est Deus noster)"; De doctrina christiana I 30; De catechizandis rudibus 49, ed. I. Bauer, CCL 46, Turnhout 1969, 172, tłum. W. Budzik: Św. Augustyn, Pisma katechetyczne, Warszawa 1952, 54-55: „Bo jeśli pragnąłeś być z owymi na widowiskach i do tych lgnąłeś, którzy razem z tobą kochali woźnicę, zapaśnika lub jakiegoś błazna, to o ileż więcej cieszyć cię powinno połączenie z miłującymi Boga. Nigdy nie powstydzi się bowiem Jego miłośnik, ponieważ nie tylko Jego samego nikt nie może zwyciężyć, lecz także swoich miłośników uczyni On niezwyciężonymi”..

${ }^{142}$ Por. Lugaresi, Il teatro di Dio, s. 693. 
że nazwał on w nim tajemnicę Wcielenia „egzemplarycznym widowiskiem”, czego nie odważył się dotąd uczynić żaden z Ojców Kościoła. Swoją mowę rozpoczyna od ubolewającego stwierdzenia, że w kościele ma tym razem mniej wiernych, bo wielu $\mathrm{z}$ nich pobiegło na przypadające $\mathrm{w}$ tym dniu widowiska do amfiteatru, w związku z czym prosi wszystkich o modlitwę za nich, by się nawrócili i nie chodzili na widowiska publiczne, opuszczając kościół w święto:

„Wielu z was, także z tych, dla których słuchanie słowa Bożego zwykło być ciężarem, celebrowało należną temu dniowi uroczystość. Teraz jednak, jak widzę, żaden z nich tu nie przyszedł, ale tylko ten, który pragnie go posłuchać. Nie mówię tu zatem do głuchych serc i niechętnych umysłów, to zaś wasze oczekiwanie na nie, jest dla mnie modlitwą. Zdarzyło się jednak coś: ponieważ i dzień igrzysk wielu stąd wywiał, o zbawienie których wielce się troszczymy i zachęcamy was, bracia, abyście i wy się troszczyli, oraz za tych, którzy nie przekonali się jeszcze do widowisk prawdy (qui nondum intenti sunt spectaculis veritatis), lecz oddali się widowiskom ciała (sed dediti sunt spectaculis carnis), proście usilnie Boga. Przekonałem się bowiem i dobrze wiem, że i wśród was są tacy, którzy dzisiaj wprawdzie za nic je mają, ale lekceważą to, co [przy chrzcie] przyrzekali. Zmieniają się bowiem ludzie na lepsze lub na gorsze. Doświadczamy tego na codzień, i cieszymy się lub smucimy: cieszymy się z ich poprawy lub smucimy z ich upadku. Dlatego też Pan nie powiedział, że zbawiony będzie ten, który zaczął, lecz powiedział, że «kto wytrwa aż do końca, ten będzie zbawiony» (Mt 10, 22). Cóż bardziej godnego podziwu mógł nam udzielić Pan nasz Jezus Chrystus Syn Boży, który jest i Synem człowieczym, że i tym raczył zostać. Cóż wspanialszego mógł uczynić niż to, że do swojej owczarni dołączył nie tylko widzów komedianckich igrzysk, lecz także tych niektórych, którzy na nich zwykli być oglądani (non solum spectatores nugacium munerum aggregaret ovili suo, sed etiam nonnullos, qui illic spectari solent). Nie tylko bowiem miłośników igrzyskowych myśliwych (amatores venatorum), lecz także samych myśliwych złowił do zbawienia (sed autem ipsos venatores venatus est ad salutem), ponieważ i sam był oglądany (quia et ipse spectatus est). Posłuchaj, w jaki sposób: sam wcześniej w proroczej obietnicy przepowiedział, że będzie oglądany, mówiąc w psalmie: «Przebodli ręce moje i nogi moje, policzyli wszystkie kości moje» (Ps 21, 17-18). Oto w jaki sposób był oglądany, skoro nawet Jego kości były policzone. Otwarcie zapowiadał to samo widowisko (ipsum spectaculum): «sami zaś się wpatrywali i mną nasycali» (Ps. 21, 17-18). Był oglądany jako wyszydzony, oglądany przez tych, którzy w tym widowisku bynajmniej mu nie klaskali, lecz przeciw niemu szaleli (spectabatur illudendus, spectabatur ab eis qui non ei saltem faverent in illo spectaculo, sed saevirent). W taki też sposób sprawił, że od początku byli oglądani jego męczennicy, informując o tym ustami Apostoła: «Staliśmy się widowiskiem dla świata, aniołów i ludzi» $(1$ Kor 4,9$)$. Lecz dwa rodzaje ludzi takie widowiska oglądają (Sed duo 
genera hominum talia snectacula spectant): jeden rodzaj ludzi cielesnych, drugi ludzi duchowych (unum carnalium, alterum spiritualium). Cieleśni oglądając je uważają, że męczennicy to tylko ludzie godni politowania, którzy rzucani są zwierzętom [na pożarcie], którzy są ścinani, którzy są ogniem przypalani, gardząc nimi i czując strach przed nimi. Drudzy natomiast ich oglądają (spectant) jak i świeci aniołowie, nie bacząc na okaleczenie ciał, lecz podziwiając zachowanie wiary. Nieustraszony duch, nawet po zniszczeniu ciała, dostarcza oczom serca wielkiego widowiska (Magnum spectaculum praebet oculis cordis integer animus corpore dissipato). Te [widowiska] wy, gdy w kościele się czyta, chętnie oglądacie oczami serca. Gdybyście bowiem nic nie oglądali, to byście też nic nie słyszeli. Widzicie zaś, ponieważ dziś nie wzgardziliście widowiskami (quod hodie spectacula non contempsistis), lecz je wybraliście. Niech Bóg będzie z wami, abyście mogli opowiedzieć w atrakcyjny sposób o waszych widowiskach waszym przyjaciołom, nad którymi ubolewacie, że dziś pobiegli do amfiteatru i nie chcieli przyjść do kościoła; aby także dla nich zaczęły tracić wartość te rzeczy, które kochając sami bez wartości się stali, i aby z wami kochali Boga, którego żaden miłośnik nie może się wstydzić, ponieważ kocha Tego, który nie może być zwyciężony. Niech z wami kochają Chrystusa, który tym samym, czym zdawał się być pokonany, zwyciężył świat. Zwyciężył świat, drodzy bracia, podbił wszystkie władze, ujarzmił królów, nie dzielnym żołnierzem, lecz wyśmiewanym krzyżem; nie srożąc się żelazem, lecz wisząc na drzewie; cierpiąc cieleśnie, działał duchowo; Jego ciało powieszono na krzyżu, a On umysły krzyżowi podbija. Tego wy kochając, nigdy nie doznacie wstydu. Jakże wielu bowiem z amfiteatru powraca zwyciężonymi, po pokonaniu tych, za których szaleją [...]. Jak wielu bowiem, sądzicie, bracia, miało dziś wątpliwości, czy iść tu, czy tam? Ci, którzy w swoim wahaniu się myśląc o Chrystusie pobiegło do kościoła, zwyciężyli nie jakiegoś człowieka, lecz samego diabła, najsprytniejszego myśliwego całego świata. Ci zaś, którzy w swych wątpliwościach wybrali pobiegnięcie do amfiteatru, przez niego oczywiście zostali pokonani, którego poprzedni zwyciężyli. Zwyciężali bowiem w Tym, który powiedział: «Cieszcie się, ponieważ ja zwyciężyłem świat» (J 16, 33). Dlatego też kusić się pozwolił Dowódca, by pouczyć żołnierza, jak walczyć"143.

Jak widać z powyższego, Augustyn obok nazwania po raz pierwszy tajemnicy Wcielenia widowiskiem, podobnym widowiskiem wewnętrznym, wytworzonym w wyobraźni słuchaczy pod wpływem kazania lub liturgicznego czytania, nazywa również, jak inni Ojcowie Kościoła, mękę i śmierć Pana oraz publiczne egzekucje męczenników. Jego nowością jest przy tym również uwaga o godnym podziwu darze Chrystusa, dopuszczającego do swej owczarni celem zbawienia (niejako złowionych do zbawienia niby do klatki - venati sunt ad salutem) nie tylko odwróconych od oglądania widowisk publicznych

${ }^{143}$ Augustinus, Sermo 51, 1. 1-2, PL 38, 353-354. 
chrześcijan (spectatores), ale i niektórych odgrywających je aktorów (etiam nonnulli qui illic spectari solent), porównując to do prezentowanych w amfiteatrze łowów. Widowiska te odbywają się jakby na scenie lub arenie: najpierw Syn Boży przyjmuje wyobcowane i wyśmiane przez diabła człowieczeństwo, potem na oczach całego świata jest On wyszydzony, męczony i ukrzyżowany (spectabatur illudendus), a później na Jego podobieństwo od początku za wiarę oddawali publicznie życie (dabant spectaculum) męczennicy. Na tych ostatnich widzowie patrzyli dwojako: cieleśni (carnales) przeważnie jak na godne politowania i wzgardy mordowane ofiary, duchowi (spirituales) zaś $\mathrm{z}$ podziwem, jak na dzielnych broniących swej wiary bohaterów.

\section{QUODVULTDEUS}

Ostatnim wreszcie wybranym przez nas starożytnym duszpasterzem, który otwarcie mówił o chrześcijańskich widowiskach zastępczych, był również afrykański biskup Quodvultdeus ( $†$ 454); czynił to w swych przedchrzcielnych katechezach, ostrzegając katechumenów przed niebezpieczeństwami widowisk publicznych, w których szatan (adversarius) głównie dwoma pokusami - przyjemnością (voluptas) i strachem (timor) wabi i zdobywa ludzi, którzy później po chrzcie często są dwulicowi ${ }^{144}$; oraz proponując w ich miejsce podsuwane przez troskliwą „świętą matkę Kościół”"145 bezpieczne, święte i chrześcijańskie widowiska w ich trzech głównych rodzajach - cyrkowych, teatralnych i amfiteatralnych:

„Unikajcie, najukochańsi, [...] widowisk, unikajcie tych najobrzydliwszych otchłani diabła (Fugite [...] spectacula, fugite caveas turpissimas diaboli), aby was nie krępowały więzy złego. Jeżeli jednak czyjś umysł nie może wyzbyć się tej uciechy i lubi je oglądać, to święta matka Kościół dostarcza wam czcigodnych i zbawiennych widowisk, które i umysły wasze cieszą swym rozweselaniem i was nie zepsują (exhibet vobis sancta mater Ecclesia veneranda et salubria spectacula, quae et mentes vestras oblectent sua delectatione),

${ }^{144}$ Por. Quodvultdeus, Sermones de symbolo I 1, 16 i 19, PL 40, 638 lub ed. R. Braun, CCL 60, Turnhout 1976, 306 i 307: „Quae sunt ista [eius] duo genera armorum? - Voluptas et timor. Alios enim voluptate capit, alios timore frangit [...]. Plures tamen noveritis, dilectissimi, capere adversarium per voluptatem, quam per timorem. Nam quare cotidie muscipulam spectaculorum insaniam studiorum ac turpium voluptatum proponit, nisi in his delectationibus capiat quos amiserat, ac laetetur denuo se invenisse quos perdiderat?”; tamże II 1, 5, PL 40, 653 lub CCL 60, 335: „Ad concupiscientiam carnis pertinent illecebrae voluptatis: ad concupiscentiam oculorum, nugacitas spectaculorum”; tamże III 1, 13-14, PL 40, 661 lub CCL 60, 350: „Deprehenderis enim et detegeris, christiane, quando aliud agis et aliud profiteris: fidelis in nomine, aliud demonstrans in opere, non tenens promissionis tuae fidem: modo ingrediens Ecclesiam orationes fundere, post modicum in spectaculis histrionibus impudice clamare. Quid tibi cum pompis diaboli, quibus renuntiasti? Utquid claudicatis ambobus inguinibus? Si Deus est, ite post illum; si muundus est, ite post illum"; zob. Weismann, Kirche und Schauspiele, s. 109-110.

${ }^{145}$ Por. Quodvultdeus, Sermones de symbolo I 1, 3, CCL 60, 305. 
lecz uchronią wiarę. A jeśli ktoś jest miłośnikiem cyrku (amator circi)? Co za przyjemność jest oglądanie w cyrku walczących woźniców, ludzi dyszących szaleńczą furią, gdy ktoś wyprzedza drugiego szybkiego i pokonuje konia swego przeciwnika? To jest cała przyjemność - krzyczeć, że zwyciężył ten, którego diabeł zwyciężył; wykrzykiwać i szydzić, że przeciwna strona straciła konia, gdy ten, którego cieszy takie widowisko (tali spectaculo delectatur), stracił zdrowy rozsądek. Ale spójrz przeciwnie, na nasze święte, zdrowe i bardzo przyjemne widowiska (vide contra nostra sancta, sana et suavissima spectacula). Zauważ w księdze Dziejów Apostolskich nigdy nie chodzącego od wyjścia z łona matki [chromego], którego Piotr uczynił biegającym; spójrz na tak szybko uzdrowionego, którego wcześniej widziałeś chorym (por. Dz 3 , 2-8). Jeśli masz jeszcze w sobie zdrowy rozsądek, jeśli w tobie działa poczucie uczciwości i pragnienie zbawienia, to zauważ, czego winieneś oczekiwać, gdzie i kiedy winieneś krzyczeć [z podziwu]? czy tam, gdzie giną zdrowe konie, czy tu, gdzie chorzy [ludzie] są uzdrawiani? Jeśli jednak pociąga cię ów przepych (pompa), ustawienie (figurae) koni, układ biegów i ozdobny strój stojącego wyżej i kierującego końmi woźnicy pragnącego zwyciężyć, jeśli cię ten przepych, jak powiedziałem, cieszy (delectat), to ci tego nie zabronił Ten, który nakazał wyrzec się przepychu (pompy) diabła. Mamy przecież i my swego duchowego woźnicę, świętego proroka Eliasza, który stojąc na ognistej kwadrydze podążył, by osiagnć metę nieba $(2 \mathrm{Krl} 2,11)$. A jeśli pragniesz oglądać jego przeciwników, których mu prawdziwa cnota dostarczyła i których on lecąc pokonał, a za ich zwyciężenie otrzymał palmę najwyższej wartości, [to masz]: «Wozy faraona i całą jego siłę rzucił w morze» (Wj 15, 4). Inny znów może, jako miłośnik teatru (theatri amator) winien być napominany, czego ma unikać, a co ma go cieszyć, i to tak, żeby chęci oglądania nie stracił, ale zmienił (ac sic voluntatem spectandi non perdat, sed mutet). W teatrach jest bowiem psucie obyczajów, nauka brzydoty, słuchanie rzeczy niemoralnych i oglądanie zgubnych. Abyśmy jednak z przekonaniem i pomocą Pana wyrzucili je zdecydowanie z naszych serc, porównajmy jedne $\mathrm{z}$ drugimi. Tam widzowie (spectatores) oglądają nie wiem już jak ukazywanego zmyślonego boga Jowisza, grzmiącego i uprawiającego cudzołóstwa, a tu widzimy prawdziwego Boga Chrystusa, uczącego czystości, wykluczającego wszelką niemoralność i głoszącego rzeczy zbawienne. Tam się zmyśla, że ten sam Jowisz ma Junonę za siostrę i żonę, a tu głosimy, że święta Maryja jest równocześnie matką i dziewica, tam wciska się twemu wzrokowi głupotę, z praktyk człowieka chodzącego po linie, a tu wielki cud - Piotra kroczącego pieszo po morzu (por. Mt 14, 29). Tam gwałci się czystość przez ukazywaną przez mimów brzydotę (mimicam turpitudinem), a tu przez przykład czystej Zuzanny (Dn 13, 8-45) i czystego Józefa (Rdz 59, 7-20) dusi się żądzę, gardzi się śmiercią, kocha się Boga i wywyższa czystość. Tam chór i śpiew [przy występach] pantomima (chorus et cantio) wabi i nęci słuch, gwałcąc zdrowe uczucia, a cóż można porównać z naszym kantykiem, w którym przemawia 
ten, który kocha i śpiewa: «Opowiadali mi grzesznicy swoje przyjemności, lecz nie takie, jak prawo Twoje, Panie» (Ps 118, 85-86). Tam bowiem próżność wszystko zmyśla. Któż ze skandalistów może tam podziwiać biegłość i oglądać małe bawiące się w powietrzu dzieci, przedstawiające różne historie. A zobaczcie zabawy naszych niemowlaków: w łonie Rebeki walczą ze sobą dwa niemowlęta - rodzący się pierwszy trzymany był za piętę wyciagniętą z łona ręką młodszego (por. Rdz 25, 22-25): w ich wzajemnej walce ukazana została figura wielkiego sakramentu, że młodszy podejdzie starszego, a potem zabierze mu pierwszeństwo i błogosławieństwo [...]. Takimi to rozrywkami umysł nasz jest tu zabawiany, a chrześcijańska dusza karmiona, tak że każdy zachowując trzeźwość swego umysłu może uniknąć opilstwa diabła.

Niech też zawody amfiteatralne (amphitheatri certamina) nie zwodzą i nie przyciągają żadnego chrześcijanina: o tyle pożądliwiej są uczęszczane, o ile później wystawiane. Lecz czegóż i tam nie ma dla oczu bardziej niebezpiecznego i krwawego?, gdzie, jak powiedział św. Cyprian, grzeszna przyjemność zabijania dzikich niewinnych zwierząt również potępia ludzi ${ }^{146}$. Niech zatem was, ukochani, i to krwawe widowisko nie zachęca do oglądania (nec illud spectaculum crudele invitet intueri), gdzie na dziewięć niedźwiedzi [poluje] dwóch zmieniających się myśliwych (altercantes venatores), lecz niech was cieszy oglądanie jednego naszego Daniela, który modląc się pokonał aż siedem lwów (por. Dn 14, 30-42). Rozróżnij, duchowy miłośniku (spiritalis amator), te walki: popatrz na dwóch żądnych przyjemności [myśliwych], i na jednego niewinnego pełnego wiary; popatrz na tych, którzy dla ziemskiej nagrody ofiarowali swe dusze zwierzętom, i na tego, który w modlitwie wołał: «Nie wydawaj zwierzętom dusz ufających Tobie» (Ps 73, 19). W tamtym widowisku fundator się smuci (in illo spectaculo contristatur editor), jeśli wyjdzie cało myśliwy, który mu zabił wiele zwierząt, a w tym naszym walczy się bez żelaza, i ani Daniel nie został zraniony, ani zwierzę zabite: tak się tu zwycięża, że król się dziwi i zmienia, ludzie są wielce przestraszeni, a nieprzyjaciele idą na zagładę (por. Dn 14, 41-42). Przedziwne są te nasze widowiska, naprawdę dziwne (Admirabile spectaculum nostrum, plane mirabile), w których Bóg wspomaga, walczy, świętość zwycięża oraz udzielana jest taka nagroda, którą otrzymuje zarówno ten, który zwyciężył, jak i ten, który ginie nic nie dając. Takich duchowych igrzysk (spiritalia munera) szukajcie, na ich podziwianie i oglądanie z pełnym bezpieczeństwem chętnie do kościoła przychodźcie, od wszelakiej cielesnej pożądliwości serca odwracajcie, wszelkie wasze troski Bogu do rozstrzygnięcia powierzajcie, aby się przeciwnik [diabeł] od was odwrócił, nie znajdując w was niczego swojego; wy zaś odwracając się od niego i wyrzekając się jego przepychów (pompis), uwolnijcie się także od jego zasadzek, aby was nigdy nie znalazł ten niegodziwiec, o którym wiemy, że pragnie trzymać [w niewoli] także nie swoich"147.

\footnotetext{
${ }^{146}$ Por. Cyprianus, Ad Donatum 7.

${ }^{147}$ Quodvultdeus, Sermones de symbolo 2-3, PL 40, 638-640 lub CCL 60, 307-310.
} 
Celowo przytoczyliśmy aż tak obszerny i prawie w całości fragment katechezy Quodvultdeusa, bo jest to chyba jedyna patrystyczna wypowiedź, ukazująca syntetycznie i razem trzy główne rodzaje starożytnych widowisk publicznych i proponowane im przeciwne chrześcijańskie widowiska zastępcze. Autor, jak widać, nie potępia zdecydowanie i nie wyklina ówczesnych publicznych widowisk jako takich, choć nazywa je caveae turpissimae diaboli i podobnie jak Tertulian i Augustyn - voluptates, ale zachęca i prosi swych słuchaczy, by ich ze względu na ukazywany niemoralny charakter unikali ( $f u$ gite). Nie żąda też od nich, by wykorzenili w sobie w ogóle chęć ich oglądania, bo jako doświadczony duszpasterz, podobnie jak św. Augustyn, dobrze wie, czym one dla starożytnych (zwłaszcza dla Afrykańczyków) są i jak się nimi pasjonuja, i byłoby to raczej niemożliwe, ale zachęca, by tej chęci oglądania nie tracili, lecz ją zmienili: voluntatem spectandi non perdant, sed mutent, zmienili na oglądanie proponowanych przez "świętą matkę Kościół” zastępczych ,widowisk czcigodnych i zbawiennych" (spectacula veneranda et salubria), które również rozweselają (oblectent sua delectatione), ale moralnie „nie psują i zachowują wiarę” (non corrumpant, sed custodiant fidem). Takich właśnie „,duchowych widowisk” (spiritalia munera), które nazywa również „przedziwnymi” (admirabilia spectacula nostra, plane mirabilia), wierni winni szukać i „na ich oglądanie i podziwianie do kościoła chętnie przychodzić" 148 . Charakteryzując zaś krótko ich trzy główne rodzaje z odpowiadającymi im widowiskami zastępczymi, Quodvultdeus przekazuje również wiele szczegółów z ich treści pogańskich i chrześcijańskich: z widowisk cyrkowych omawia tylko wyścigi konne woźniców na kwadrygach, którym przeciwstawia chrześcijańskie nostra sancta, sana et suavissima spectacula: opisane w Dziejach Apostolskich uzdrowienie przez św. Piotra chromego od urodzenia oraz w Księgach Królewskich - unoszącego się do nieba na ognistym wozie proroka Eliasza; $\mathrm{z}$ widowisk teatralnych wymienia przedstawienia mima i pantomima przedstawiających cudzołóstwa i niemoralność Jowisza, którym przeciwstawia święte biblijne postacie - Maryję jako matkę i dziewicę, św. Piotra kroczącego po morzu, przykłady zachowań czystej Zuzanny i Józefa Egipskiego, oraz rzadko w tym kontekście proponowaną (chyba tylko przez Quodvultdeusa) scenę wzajemnej walki podczas narodzin Ezawa i Jakuba; wreszcie z amfiteatralnych pogańskich - polowanie (venationes) dwóch myśliwych na niedźwiedzie, któremu przeciwstawiony jest biblijny zwycięski Daniel w jamie z lwami. Wszystkie wyżej wymienione chrześcijańskie, a zaczerpnięte tylko z Biblii sceny jako widowiska zastępcze (z wyjątkiem narodzin Ezawa i Jakuba) znane były wcześniej i proponowane także później

${ }^{148}$ Podobnie niespełna 150 lat później w Italii będzie pisał Kasjodor $(\dagger 580)$, por. Expositio Psalmorum 39, 6, ed. M. Adriaen, CCL 97, Turnhout 1958, 365: „Nam qui inflammantur contendentibus aurigis, qui pantomimis saltantibus molliuntur, quanto melius si cogitent coelum et terram pulcherrima diversitate formata [...]. Numquid tale est scenicas audire tragoedias, quale est in choris Ecclesiae salutiferas cognoscere psalmodia". 
przez Ojców Kościoła, miały zastępować i zaspokajać pragnienie oglądania widowisk przez wiernych.

\author{
CHRISTIAN SUBSTITUTE SPECTACLES \\ IN PROPOSAL OF CERTAIN CHURCH FATHERS
}

(Summary)

The Church Fathers presented a decidedly negative stance toward all public spectacles of their time, which they generally accused of being immoral and idolatrous in nature. For this reason, the ancient Church, although it has inherited many spectacular elements (especially in the area of liturgy - processions and acclamations, among others; and in the sphere of the language - many terms, expressions and comparisons), has never created its own drama.

Many authors of that time, especially those concerned with pastoral implications, noticed that this definitely negative attitude was failing in practice, because many Christians, even though they had renounced the spectacular splendor of the devil at baptism, often attended spectacles, because it was very difficult to eradicate their desire to watch performances, which they treated as a public pleasure they are entitled to (voluptates).

In response to this situation, many early Christian writers renounced efforts to uproot people's desire for viewing pleasure, and proposed to change the subject being viewed. Instead of harmful public spectacles, they suggested watching Christian substitute performances, which included beautiful scenery of nature (as was already suggested by some stoics), but most often more expressive biblical scenes or events.

The author of the article selects and presents five early Christian writers - Tertullian, Novatian, St. John Chrysostom, St. Augustine and Quodvultdeus, who openly wrote about such substitute Christian performances.

Key words: Early Christian attitude to the spectacles, ancient public spectacles, early Christian alternative spectacles.

Słowa kluczowe: wczesnochrześcijański stosunek do widowisk, starożytne widowiska publiczne, wczesnochrześcijańskie widowiska zastępcze.

\title{
BIBLIOGRAFIA
}

\section{Źródła}

Augustinus, De catechizandis rudibus, ed. I. Bauer, CCL 46, Turnhout 1969, 121-178, tłum. W. Budzik: Św. Augustyn, Pisma katechetyczne, Warszawa 1952, 1-60.

Augustinus, De Trinitate, ed. W.J. Mountain - F. Glorie, CCL 50, Turnhout 1968, thum. M. Stokowska, POK 25, Poznań 1963. 
Augustinus, De vera religione, ed. K.-D. Daur, CCL 32, Turnhout 1962, lub PL 34, 121 172, tłum. J. Ptaszyński: Św. Augustyn, O prawdziwej wierze, w: Św. Augustyn, Dialogi filozoficzne, Kraków 1999, 733-818.

Augustinus, Enarrationes in Psalmos, ed. D.E. Dekkers - I. Fraipont, CCL 38-40, Turnhout 1956, tłum. J. Sulowski: Św. Augustyn, Objaśnienia Psalmów, PSP 37-42, Warszawa 1986.

Augustinus, In Joannis evangelium tractatus CXXIV, ed. R. Willems, CCL 36, Turnhout 1954, 1-688, tłum. W. Szołdrski - W. Kania: Św. Augustyn, Homilie na Ewangelie i Pierwszy List św. Jana, PSP 15/1, Warszawa 1977, 27-551; PSP 15/2, Warszawa 1977, 9-379.

Augustinus, Sermo 9, PL 38, 75-91.

Augustinus, Sermo 51, PL 38, 332-354.

Augustinus, Sermo 345, PL 39, 1517-1522.

Augustinus, Sermones (273-340A), ed. A. Quacquarelli - M. Recchia, NBA 33, Roma 1986.

Basilius Caesariensis, De Spiritu Sancto, éd. B. Pruche, SCh 17bis, Paris 1968, tłum. A. Brzóstkowska: Św. Bazyli, O Duchu Świętym, Warszawa 1999.

Cassiodorus, Expositio Psalmorum, ed. M. Adriaen, CCL 97, Turnhout 1958.

Cicero, De natura deorum Cicero, ed. J.B. Mayor, vol. 1-3, Cambridge 1880-1885.

Cyprianus, De opere et eleemosynis, ed. M. Simonetti, CCL 3A, Turnhout 1976, 55-72, tłum. J. Czuj, POK 19, Poznań 1937, 324-347.

Eusebius Caesariensis, De martyribus Palaestinae, ed. G. Bardy, SCh 55, Paris 1967, 120 174, tłum. A. Lisiecki, POK 3, Poznań 1924, 463-495.

Jacobus Sarugensis, De ludis theatralibus, ed. C. Moss: Jacob of Serugh, Homilies on the spectacles of the theatre, „Le Muséon” 48 (1935) 87-112.

Joannes Chrysostomus, Ad eos qui scandalizati sunt, éd. A.-M. Malingrey, SCh 79, Paris $1961,52-276$.

Joannes Chrysostomus, Ad populum Antiochenum homiliae, PG 49, 15-222.

Joannes Chrysostomus, Ad Theodorum lapsum, éd. J. Dumortier, SCh 117, Paris 1966.

Joannes Chrysostomus, Adversus Judaeos, PG 48, 843-942, tłum. J. Iluk w tegoż: $\dot{Z} y$ dowska politeja i Kościół w Imperium Rzymskim u schytku antyku, t. 1, Gdańsk 2006, 51-270.

Jonnnes Chrysostomus, Contra ludos et theatra, PG 56, 263-270, thum W. Kania, PSP 8, Warszawa 1971, 175-181.

Joannes Chrysostomus, De inani gloria et de educandis liberis, éd. A.-M. Malingrey, SCh 188, Paris 1972, 64-196, thum. W. Kania, PSP 13, Warszawa 1974, 157-185 lub BOK 19, Kraków 2002, 73-105.

JoAnnes Chrysostomus, De Lazaro con., PG 48, 963-1054.

JoAnnes Chrysostomus, De Maccabaeis hom. 1-2, PG 50, 617-626, tłum. W. Kania, PSP 8, Warszawa 1971, 150-155.

Joannes Chrysostomus, De Meletio Antiocheno, PG 50, 515-520, tłum. W. Kania, PSP 8, Warszawa 1971, 162-167.

Jonnnes Chrysostomus, Epistulae ad Olympiadem, ed. A.-M. Malingrey, SCh 13bis, Paris 1968, tłum. W. Kania, BOK 19, Kraków 2002, 205-250.

Joannes Chrysostomus, In Acta Apostolorum hom., PG 60, 13-384.

JoAnnes Chrysostomus, In epistulam ad Colossenses hom., PG 62, 299-392.

JoAnnes Chrysostomus, In epistulam I ad Corinthios hom., PG 61, 9-382.

Joannes Chrysostomus, In epistulam II ad Corinthios hom., PG 61, 381-610. 
Joannes Chrysostomus, In epistulam II ad Timotheum hom., PG 62, 599-662, tłum. T. Sinko: Św. Jan Złotousty, Homilie na Listy Pasterskie św. Pawła I i na List do Filemona, Kraków 1949, 193-304.

JoAnnes Chrysostomus, In epistulam ad Hebraeos hom., PG 63, 9-236.

JoAnnes Chrysostomus, In Genesin serm., PG 53, 21-385; 54, 385-580.

JoAnnes Chrysostomus, In illud Isaiae dictum: „,Ego Dominus Deus feci lumen”, PG 56, 141-152.

JoAnnes Chrysostomus, In illud: ,, Vidi Dominum” homiliae, PG 56, 97-142.

Joannes Chrysostomus, In Joannem hom., PG 59, 23-482.

JoAnnes Chrysostomus, In martyres hom., PG 50, 661-665.

JoAnnes Chrysostomus, In Matthaeum hom., PG 57, 13 - 58, 794, tłum. J. Krystyniacki (hom. 1-40, 61-90) - A. Baron (hom. 41-60), ŹMT 18 i 23, Kraków 2000 i 2001.

Joannes Chrysostomus, In S. Barlaam martyrem, PG 50, 675-682.

Joannes Chrysostomus, In S. Ignatium martyrem, PG 50, 587-596, tłum. W. Kania, BOK 19, Kraków 2002, 179-192.

JoAnnes Chrysostomus, Quod nemo laeditur nisi a seipso, PG 52, 459-480.

Joannes Mandacunius, Homilia 17: Contra ludos theatrales, übers S. Weber, BKV 58, 1. Reihe, Kempten - München 1927, 184-192.

Juvenalis, Saturae, ed. J.D. Duff, Cambridge 1966.

Lactantius, Divinae institutiones, ed. S. Brandt - G. Laubmann, CSEL 19, Vindobonae 1890.

Minucius Felix, Octavius, ed. C. Halm, CSEL 2, Vindobonae 1867, thum. M. Szarmach, PSP 44, Warszawa 1988, 20-77.

Novatianus, De spectaculis, ed. G.F. Diercks, CCL 4, Turnhout 1972, 167-179, lub ed. A. Saggioro: Novaziano, Gli spettacoli, Introduzione, testo, traduzione e commento, BPatr 37, Bologna 2001, thum. pol. zbiorowe, wstęp M. Eder, „Meander” 56 (2002) nr 2, 69-75.

Quodvultdeus, Sermones de Symbolo, ed. R. Braun, CCL 60, Turnhout 1976, 303-363 lub PL 40, 637-668.

SenecA, Epistulae morales ad Lucillium, ed. R.M. Gummere, t. 1-3, London - New York 1917-1925.

Salvianus Massiliensis, De gubernatione Dei VI, éd. G. Lagarrigue, SCh 220, Paris 1975, 360-429, tłum. T. Kołosowski: Salwian z Marsylii, O rzadach Boga, w: Salwian z Marsylii, Dzieła wszystkie, PSP 66, Warszawa 2010, PSP 66, 197-219.

Tertullianus, Apologeticum, ed. E. Dekkers, CCL 1, Turnhout 1954, 77-172, thum. J. Sajdak, POK 20, Poznań 1947.

Tertullianus, De spectaculis, ed. E. Dekkers, CCL 1, Turnhout 1954, 227-253 lub ed. M. Turcan, SCh 332, Paris 1986, thum. W. Myszor, PSP 5, Warszawa 1970, 79-113.

\section{Opracowania}

BAumeister T., Das Theater in der Sicht der alten Kirche, w: Theaterwesen und dramatische Literatur, hrsg. G. Holtus, Tübingen 1987, 109-124.

Burliga B., Tertullian on the paradox of the Roman amphitheatre games (De spectaculis 22), VoxP 36 (2016) t. 65, 119-127.

Colish M.L., The stoic Tradition from Antiquity to the early Middle Ages, vol. 2: Stoicism in Christian Latin thought, Leiden 1985, 9-29.

Daniélou J., Le origini del cristianesimo latino. Storia delle dottrine cristiane prima di Nicea, Bologna 1991. 
Eriau J.B., Pourquoi les Pères de l'Église ont condamné le théatre de leur temps, Paris - Angers 1914.

Fredouille J.C., Tertullien et la conversion de la culture antique, Paris 1972.

Jeux et spectacles dans l'antiquité tardive, ed. J.-M. Carrié, Turnhout 2007 = „Antiquité Tardive" 15 (2007).

Jürgens H., Pompa diaboli. Die lateinischen Kirchenväter und das antike Theater, Stuttgart 1972.

KesSLER A., Tertullian und das Vergnügen in „De spectaculis”, „Zeitschrift für Philosophie und Theologie" 41 (1994) 313-353.

KLEIN R., ,Spectaculorum voluptates adimere”. Zum Kampf der Kirchenväter gegen Circus und Theater, w: Theater, Theaterpraxis, Theaterkritik im Kaiserzeitlichen Rom, hrsg. J. Fugmann, München - Leipzig 2004, 155-174.

Longosz S., Dramatyzowane homilie patrystyczne zalażkiem dramatu chrześcijańskiego, VoxP 36 (2016) t. 65, 389-431.

Longosz S., Teatr miejscem kultu bóstw pogańskich $w$ opinii autorów wczesnochrześcijańskich, „Acta Universitatis Nicolai Copernici. Historia” 27 (1992) t. 254, 135-149

Longosz S., Widowiska teatralne zagrożeniem dla życia rodzinnego wedtug św. Jana Chryzostoma. Wprowadzenie i wybór tekstów, w: Chrześcijanie a życie publiczne $w$ Cesarstwie Rzymskim III-IV wieku, red. J. Śrutwa, Lublin 1988, 135-198.

Longosz S., Zalażki dramatu chrześcijańskiego w literaturze patrystycznej, RH 44 (1996) z. 3, 263-273.

Lugaresi L., Il teatro di Dio. Il problema degli spettacoli nel cristianesimo antico (II-IV secolo), Brescia 2008.

Lugaresi L., Vanitas ludus omnis. Il problema degli spettacoli nel cristianesimo antico (II-V secolo), Diss., Bologna - Paris 2006.

Moreschini C., Tertulliano tra stoicismo e platonismo, w: Kerygma und Logos. Festschrift C. Andresen, Göttingen 1979, 167-179.

Mosci Sassi M.G., Una proposta di lettura a Tert. Spect. 29, 5, „Res Publica Litterarum” 12 (1989) 139-143.

Myszon W., Teatr $i$ widowiska w ocenie greckich pisarzy kościelnych, w: Chrześcijanie a życie publiczne $w$ Cesarstwie Rzymskim III-IV wieku, red. J. Śrutwa, Lublin 1988, 123-134.

Pasquato O., Gli spettacoli in S. Giovanni Crisostomo. Paganesimo e cristianesimo ad Antiochia e Costantinopoli nel IV secolo, Roma 1976.

Poque S., Spectacles et festins offerts par Augustin d'Hippone pour les fêtes des martyrs, „Pallas” 15 (1968) 103-125.

PotTer D.S., Martyrdom as spectacle, w: Theater and society in classical world, ed. R. Scodel, Ann Arbor 1992, 53-88.

Potter D.S.,, Death as spectacle and subsequent disposal, ,Journal of Roman Archeology" 14 (2001) 475-484.

Power V., Tertullian: father of clerical animosity toward the theatre, „Educational Theatre Journal" 23 (1971) 36-50.

Prete S., L'Antico Testamento in Novaziano: De spectaculis 10, „Augustinianum" 22 (1982) 229-237.

Rahner H., Pompa diaboli. Ein Beitrag zur Bedeutungsgeschichte des Wortes pompepompa in der urchristlichen Taufliturgie, ZKTh 55 (1931) 239-273.

Rambaux C., Tertullien face aux morales des trois premiers siècles, Paris 1979.

SAWHILl J.A., The use of atletic metaphors in the biblical homilies of St. J. Chrysostom, Princeton 1928 
Schlapbach K., Spectaculum naturae as ,, theatrical” experience: new uses of an ,old comparison", StPatr 44 (2011) 421-426

Schnusenberg Ch., Das Verhältnis von Kirche und Theater. Dargestellt an ausgewählten Schriften der Kirchenväter und liturgischen Texten, Bern - Frankfurt 1981.

SchöLlgen G., Die Teilnahme der Christen am städtischen Leben in vorkonstantinischer Zeit. Tertullians Zeugnis für Karthago, RQ 77 (1982) 1-29.

SŁAPEK D., Sport $i$ widowiska $w$ świecie antycznym. Kompendium, Kraków - Warszawa 2010.

Spanneut M., Le stoïcisme des Pères de l'Église, Paris 1957.

Spanneut M., Les normes morales du stoicïsm chez les Pères de l'Église, „Studia Moralia” 19 (1981) 153-175.

Spectacula, ed. M. Vinzent - K. Schlapbach, Leuven - Paris 2013 = StPatr 60 (2013).

ŚRUTwA J., Widowiska epoki klasycznej w ocenie Kościoła afrykańskiego II-V wieku, RTK 27 (1980) z. 4, 43-56.

Stanula E., Widowiska w ocenie Ojców Kościoła, SaeCh 1 (1995) 7-16.

VANDEnBerhe B.H., Saint Jean Chrysostome et les spectacles, ZRGG 7 (1955) 34-46.

Vogt H.J., Coetus sanctorum. Der Kirchenbegriff des Novatian und die Geschichte seiner Sonderkirche, Bonn 1968.

WAGNER F., Geschichte der Sittlichkeitsbegriffes, Bd. 2: Der Sittlichkeitsbegriff in der Hl. Schrift und in der altchristlichen Ethik, Münster 1931.

WaszinK J.H., Pompa diaboli, VigCh 1 (1947) 13-41

Weismann W., Kirche und Schauspiele. Die Schauspiele im Urteil der lateinischen Kirchenväter, unter besonderer Berücksichtigung von Augustin, Würzburg 1972.

Wolf P., Die Stellung der Christen zu den Schauspielen nach Tertullians Schrift „De spectaculis”, Leipzig 1897.

ZAWADZKA M., Kilka uwag o wschodniochrześcijańskiej krytyce rzymskich widowisk (na podstawie ,De spectaculis” Tertuliana, „,De spectaculis” Nowacjana, ,De gubernatione Dei VI" Salwiana z Marsylii, VoxP 24 (2004) t. 46-47, 433-439. 